
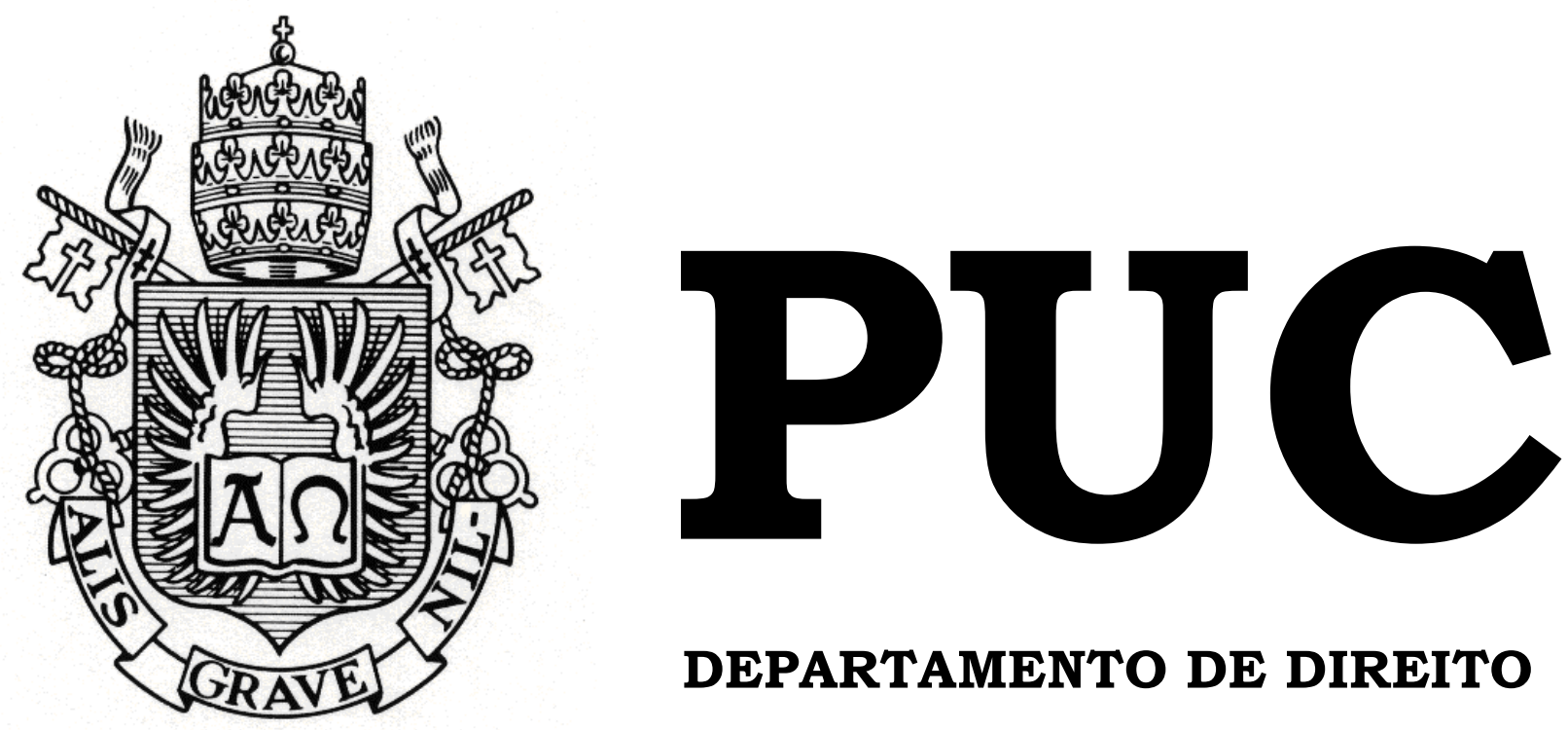

DEPARTAMENTO DE DIREITO

\title{
DISCLOSURE DA REMUNERAÇÃO DE ADMINISTRADORES DE COMPANHIAS ABERTAS
}

por

JOÃO PAULO DE CARVALHO GEORGIEF

ORIENTADOR: MARCELO FERNANDEZ TRINDADE

2013.2

PONTIFÍCIA UNIVERSIDADE CATÓLICA DO RIO DE JANEIRO

RUA MARQUÊS DE SÃO VICENTE, 225 - CEP 22453-900

RIO DE JANEIRO - BRASIL 


\title{
DISCLOSURE DA REMUNERAÇÃO DE ADMINISTRADORES DE COMPANHIAS ABERTAS
}

\author{
por \\ JOÃo PAULO DE CARVALHO GEORGIEF
}

Monografia

apresentada ao

Departamento de Direito da

Pontificia Universidade Católica do Rio de Janeiro (PUC-Rio) para a obtenção do Título de Bacharel em Direito.

Orientador: Marcelo Fernandez Trindade 
A meus pais e avós, com muito amor 


\section{Agradecimentos}

Do modo como vejo, este trabalho simboliza o encerramento de um ciclo de minha vida. Por mais que sua pretensão acadêmica seja bastante reduzida, não posso deixar de aproveitá-lo para agradecer a várias pessoas que me foram especiais durante este período.

Em primeiro lugar, este trabalho seria impossível sem meus pais e avós, a quem dedico este trabalho, pois me criaram, amaram e educaram. O agradecimento a eles é o primeiro e mais importante de todos. Devo tudo a Celso, Júlia, Oswaldo, Dimiter, Maria de Fátima e Ignez.

Agradeço a meu orientador, Marcelo Trindade, pelo carinho com que me acolheu em seu escritório e pela confiança que me deu. A vivacidade de suas aulas e a busca pela perfeição na pesquisa e na escrita foram uma grande inspiração. Agradeço também a Fabiana Almeida, que me inspirou a abraçar este tema e foi uma co-orientadora não oficial, além de uma amiga. Aprendemos juntos várias questões que tocam este trabalho. Espero, com sua qualidade, honrar o ensinamento de ambos.

Agradeço também a todos os meus amigos do Rio de Janeiro que me acompanharam nestes últimos anos, pelo carinho e pela companhia. Às vezes consegui retribuí-los, às vezes não. Contudo, a vontade de fazê-lo da forma mais bonita e eloquente sempre esteve presente. Dentre eles, agradeço em especial a Daniel Torres Teixeira, Carlos Magno Valle, Felipe Mendonça Russo, Carlos Eduardo Mello, Rodrigo Leitão Requena, Diego Dias, Felipe Schvartzman, Lucas Mariano Lima, Isaura Salgado, Priscilla Ribeiro, Eduardo Stellman Gambôa Jr., Vinicius Cozzolino, Pedro Duarte Jr., Germano Pires, Camila David Garcia, Jacqueline Tardelli, Marília Lopes, Fernanda Bokel, Astrid Lima Rocha e Aline Osório. A Daphne Costa Besen, que tem me acompanhado praticamente desde o início deste 
projeto, agradeço pelo carinho, amizade e paciência que tornaram tudo mais simples e prazeroso.

Agradeço também a meus professores, por terem me dado uma boa educação e incentivo ao aprendizado. A eles sou grato por me terem transmitido o hábito da leitura e o pouco de disciplina que tenho.

Não posso deixar de lembrar de meus colegas e chefes nos escritórios Lobo e Ibeas Advogados, Trindade Sociedade de Advogados e Leoni Siqueira Advogados, a quem devo o acolhimento na advocacia e o incentivo à pesquisa e ao estudo do direito empresarial. De certa forma, também foram meus professores, e por isso os agradeço em dobro. Neste quesito, não posso deixar de agradecer a Paulo Eduardo Penna por ter, nos últimos momentos, me dado insights valiosos. 


\section{Resumo}

O presente trabalho visa a analisar os problemas gerados pela remuneração dos administradores de companhias abertas e o mandatory disclosure como uma técnica para sua solução ou mitigação. Primeiramente, o Autor, após reconhecer a relevância do problema, se concentra na sua análise econômica, sob a ótica do modelo Jensen-Meckling de governança corporativa, sem, contudo, desconsiderar considerações feitas por outros modelos. São analisados os fundamentos econômicos desse modelo, como, dentre outros, a existência de custos de transação e de custos de agência. Em um segundo momento o Autor analisa o histórico do debate sobre a remuneração de administradores de companhias abertas nos EUA e no Brasil, associando, sempre que possível, a iniciativas normativas e outras soluções, com um foco posterior no mandatory disclosure. Posteriormente, a juridicidade de iniciativa regulatória pela CVM para a solução do problema é analisada, dando-se especial atenção às questões suscitadas pelo atual debate sobre a ICVM 480. A Autor conclui que, no Brasil, a CVM atualmente possui o poder normativo para regular a matéria, especialmente para determinar seu disclosure nos termos da ICVM 480. Contudo, é reticente quanto à necessidade de atuação de órgão regulador para solucionar o problema de forma heterônoma.

Palavras chaves: remuneração, administrador, companhia aberta, divulgação, disclosure, governança corporativa 


\section{Sumário}

1. Introdução: O Problema da Remuneração dos Administradores ............. 8

2. Pressupostos teóricos ......................................................................... 15

2.1. Governança corporativa....................................................... 15

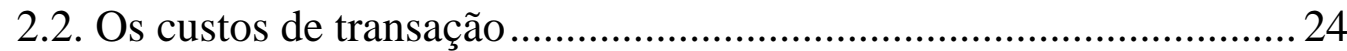

2.3. O interesse social ...................................................................... 28

2.3.1. A companhia não possui interesse: corolário do contractarianism

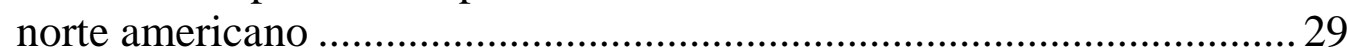

2.3.2. Posição contingente: o interesse da companhia é o de seus

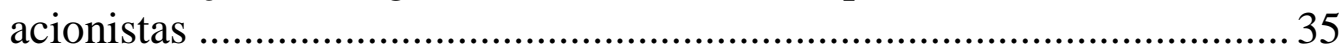

2.4. O problema principal-agente .................................................. 43

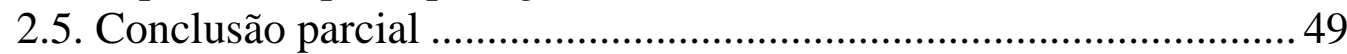

3. O Problema da Remuneração dos Administradores de Companhias

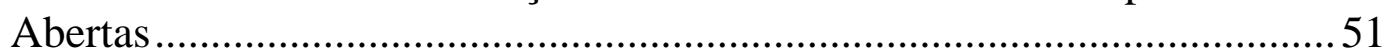

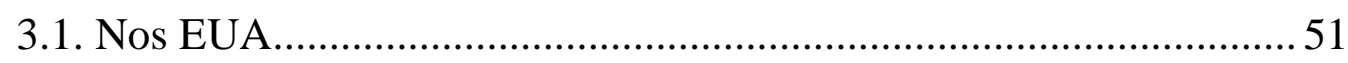

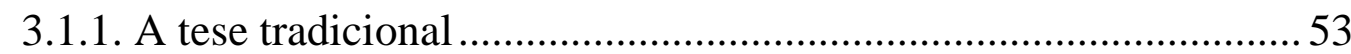

3.1.2. Pay without performance .......................................................... 55

3.1.2. O estado atual: do Sarbanes-Oxley Act para o Dodd-Frank Act .. 62

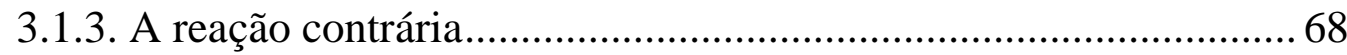

3.2. No Brasil ................................................................................... 72

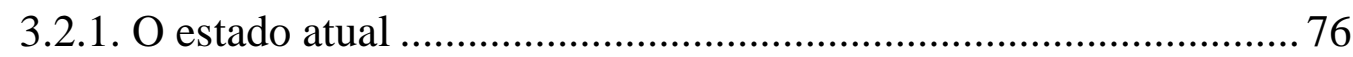

3.3. Conclusão parcial ...................................................................... 81

4. Juridicidade da Regulação da Matéria.................................................... 86

4.1. A regulação do mercado de capitais e a Lei n. 6.385/76 ................. 87

4.2. Valores mobiliários, competência da CVM e a ICVM 480 ............ 90

4.2.1. Valeurs mobilières: a inspiração francesa .................................. 90

4.2.2. Collective investment schemes: o inciso interminável da Lei

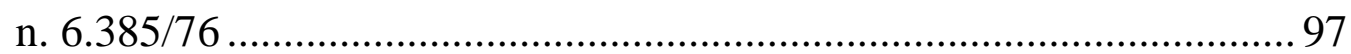

4.3. Juridicidade dos atos normativos da CVM.................................. 104

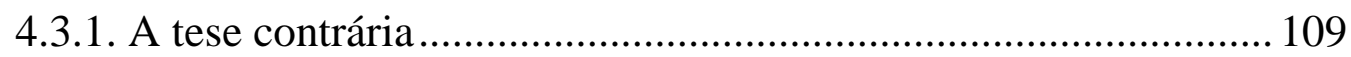

4.3.2. Teses favoráveis ..................................................................... 114

4.3.2.1. A delegação permitida ....................................................... 115

4.3.2.2. A discricionariedade técnica.................................................... 119

4.3.2.3. Agências reguladoras como um Poder "à parte" ...................... 124

4.3.2.4. Poder normativo e delegação.................................................. 125

4.3.3. Conclusão parcial in abstrato: a posição do Autor ..................... 128

4.3.4. Conclusão parcial in concreto: a ação IBEF v. CVM ................ 130

4.3.4.1. Contrariedade ao art. 152 da LSA .......................................... 131

4.3.4.2. Contrariedade ao art. $157, \S 1^{\circ}$, alíneas $c$ e $d$, da LSA ............ 132

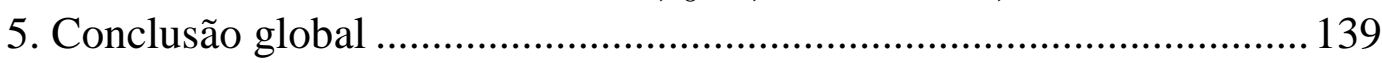

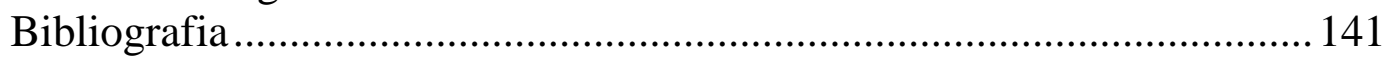




\section{Lista de Abreviações}

\begin{tabular}{|c|c|}
\hline Abreviação & Significado \\
\hline ABA & American Bar Association \\
\hline ADCT & Ato das Disposições Constitucionais Transitórias \\
\hline ALI & American Law Institute \\
\hline AMEX & American Stock Exchange \\
\hline BACEN & Banco Central do Brasil \\
\hline BM\&FBOVESPA & $\begin{array}{l}\text { BM\&FBOVESPA S.A. - Bolsa de Valores, } \\
\text { Mercadorias e Futuros }\end{array}$ \\
\hline BOVESPA & Bolsa de Valores do Estado de São Paulo \\
\hline CCDVT & Caisse Centrale de Dépôts et Virements des Titres \\
\hline $\mathrm{CMN}$ & Conselho Monetário Nacional \\
\hline CRFB & Constituição da República Federativa do Brasil \\
\hline CRSFN & $\begin{array}{l}\text { Conselho de Recursos do Sistema Financeiro } \\
\text { Nacional }\end{array}$ \\
\hline CVM & Comissão de Valores Mobiliários \\
\hline EUA & Estados Unidos da América \\
\hline IBEF & Instituto Brasileiro dos Executivos de Finanças \\
\hline ICVM & $\begin{array}{l}\text { Instrução Normativa da Comissão de Valores } \\
\text { Mobiliários }\end{array}$ \\
\hline LSA & Lei n. 6.404 , de 15.12 .1976 \\
\hline NYSE & New York Stock Exchange \\
\hline OCDE & $\begin{array}{l}\text { Organização para a Cooperação e } \\
\text { Desenvolvimento Econômico }\end{array}$ \\
\hline RU & Reino Unido \\
\hline SEC & Securities Exchange Commission \\
\hline SUMOC & Superintendência da Moeda e do Crédito \\
\hline
\end{tabular}




\section{Introdução: $O$ Problema da Remuneração dos Administradores}

Este é um trabalho sobre regulação do mercado de capitais, direito societário e - o Autor ousa arriscar-se - governança corporativa.

Com efeito, governança corporativa tem sido um dos mantras mais repetidos na literatura de direito empresarial e nas disputas societárias nos últimos anos. A repetição da expressão na literatura, principalmente a partir da década de 1970, pode levar um leitor precavido (e razoavelmente cético) a acreditar que a expressão ganhou conotação retórica e que, neste quesito, este trabalho não difere dos demais.

Contudo, o Autor deste trabalho prefere pensar que a expressão "governança corporativa" tem um significado bem definido e pode ser algo levado a sério por empresários, acadêmicos e operadores do Direito. Por este motivo empreende, logo no primeiro capítulo, uma jornada às raízes da noção e do movimento para definir seu conteúdo e sua relevância para o mundo jurídico. A análise da remuneração dos administradores de companhias abertas é empreendida do ponto de vista jurídico e de governança corporativa porque as raízes dos problemas são tanto jurídicas quanto organizacionais e econômicas. ${ }^{1}$

Um estudo sobre o disclosure não pode se restringir ao estudo da competência normativa da CVM e de seus atos normativos relacionados. Tudo isto será examinado ao longo deste trabalho e o Autor oportunamente irá se posicionar sobre a juridicidade de certas questões. Contudo, isto não esgota a polêmica em torno deste tema.

\footnotetext{
${ }^{1}$ Érica Gorga nota, em sua recente obra, que "[o] objeto social da sociedade anônima é econômico. Também o mercado de capitais é econômico por excelência. Uma vez que não seja deixado ao arbitrio da "mão invisivel", os agentes reguladores devem ter em mente que qualquer tipo de regulação ensejará um determinado efeito na organização e na alocação econômica do mercado." GORGA, Érica. Direito Societário Atual. Rio de Janeiro: Elsevier, 2013. p. 4.
} 
O Autor, portanto, está empreendendo um estudo de Law and Economics, pois analisa os efeitos do direito positivo sobre as relações econômicas e, inversamente, analisa como os fenômenos econômicos inspiram as mudanças jurídicas (seja no campo a regulação, seja no da autorregulação).

De fato, estudos sistemáticos sobre a remuneração dos administradores de companhias, tanto abertas quanto fechadas, somente recentemente ganharam evidência na academia. ${ }^{2}$ Por mais que críticas ao valor das remunerações existissem há muito mais tempo, foi somente na década de 1930 que se abriu caminho para maiores discussões sobre a organização empresarial do ponto de vista econômico e jurídico - e, portanto, os incentivos e os desincentivos dos administradores das companhias. $^{3}$

Foi também na década de 1930 que o tema ganhou contornos políticos e a atenção da sociedade civil norte americana. $\mathrm{Na}$ época, foram inflamados os argumentos contra os valores supostamente exorbitantes percebidos por administradores. ${ }^{4}$

\footnotetext{
${ }^{2}$ Evidentemente, um corte temporal teve que ser feito pelo Autor. Comentários esparsos e pouco sistemáticos sobre a governança das empresas e o papel dos administradores podem ser encontrados em The Wealth of Nations, de Adam Smith: "The directors of such [joint-stock] companies, however, being the managers rather of other people's money than of their own, it cannot well be expected, that they should watch over it with the same anxious vigilance with which the partners in a private copartnery frequently watch over their own. Like the stewards of a rich man, they are apt to consider attention to small matters as not for their master's honour, and very easily give themselves a dispensation from having it. Negligence and profusion, therefore, must always prevail, more or less, in the management of the affairs of such a company." SMITH, Adam. The Wealth of Nations, editado por Edwin Cannan, v. 1. Londres: Methuen, 1904. p. 237.

${ }^{3}$ Esta é a visão da maior parte da literatura norte americana. Trata-se da obra BERLE, Adolf A.; MEANS, Gardiner C. The Modern Corporation and Private Property. Transaction, 1991. 380 p., originalmente publicada em 1932, e do artigo COASE, Ronald $\mathrm{H}$. The Nature of the Firm. Economica, New Series, vol. 4, n. 16, nov. 1937. pp. 386-405.

${ }^{4}$ Harwell Wells, no primeiro estudo publicado sobre a remuneração dos diretores norte americanos na década de 1930, comenta: "Before the 1930s, the compensation of executives was not a matter of public record, and most publicly held corporations declined to publicize or even discuss the pay of their senior managers. A chain of disclosures between 1930 and 1933 swept away this privacy norm and propagated the image of executives as immoral, overpaid, and self-serving, taking home huge paychecks while most Americans faced wage cuts or unemployment." WELLS, Harwell. "No
} 
Foi somente em 1970, contudo, que a discussão ganhou contornos distintos. As ideias de da década de 1930 culminaram em estudos sobre a organização empresarial e os incentivos que a remuneração pode fornecer aos administradores. Na mesma década, estas ideias saíram da academia e forma incorporadas no corporate governance movement que se alastrou pelos EUA na mesma década e na Europa na década de $1990 .{ }^{5}$ Nas palavras de Joel Seligman, "[a] década de 1970 foi testemunha da consideração sobre reforma corporativa mais significativa desde o período do New Deal." A discussão de 1970 em diante, contudo, era mais aprofundada e lembrava pouco a da década de $1930 .^{7}$

O surgimento de uma série de estudos sobre o tema - e o consequente refinamento do debate - é, evidentemente, fruto de fatos históricos. No início do século XX, remunerar administradores era proibido na maior parte dos Estados norte americanos. Pressupunha-se que os administradores das companhias eram também acionistas delas ou outros tipis de insiders - e desta posição de insider, jamais de administrador, adviria o incentivo para sua boa performance. ${ }^{8}$ Este pressuposto, evidentemente, não durou muito tempo - o cenário já era completamente diferente vinte anos depois, tendo as cortes e os legisladores dos Estados permitido a remuneração de administradores outsiders. ${ }^{9}$ O Autor pondera

Man Can Be Worth \$1,000,000 a Year”: the fight over executive compensation in 1930s America. University of Richmond Law Review, n. 44, 2009-2010. p. 693.

5 ABREU, Jorge Manuel Coutinho de. Governação das Sociedades Comerciais. $2^{\mathrm{a}}$ ed. Coimbra: Almedina, 2010. pp. 9-11.

${ }^{6}$ SELIGMAN, Joel. The Transformation of Wall Street. $3^{\mathrm{a}}$ ed. Nova Iorque: Wolters Kluwer, 2003. p. 534.

7 "The fight over executive compensation in the 1930s engaged deep questions about the nature of the corporation and the rewards due labor, hinting that there was a limit to the pay any man could fairly demand. We now take those questions as settled and no longer ask whether there is a sum too much for any man to earn. The contemporary debate thus addresses a narrower, less morally charged question: whether executive compensation is properly structured to incentivize executives to maximize shareholder value. The differences between the two debates measures the changes in our way of thinking about executive compensation and the corporation over the past seventy years." WELLS, Harwell. Op. cit. p. 694.

${ }^{8}$ BAINBRIDGE, Stephen M. The New Corporate Governance in Theory and Practice. Nova Iorque: Oxford University Press, 2008. p. 167.

${ }^{9}$ Id., ibid. p. 167. 
que talvez esta dissociação das duas posições (acionista e administrador) tenha permitido o estudo mais aprofundado deste tema na segunda metade do século XX.

No Brasil, desde no mínimo o Decreto-Lei n. 2.627/40, a remuneração de administradores era permitida - administradores não, diretores, uma vez que o Decreto-Lei n. 2.627/40 não previa a existência de outros órgãos da administração que não a diretoria. $\mathrm{O}$ art. $116, \S 1^{\circ}$, alínea $b$, obrigava que do estatuto social das sociedades anônimas constasse previsão acerca da remuneração dos diretores. ${ }^{10}$ Curiosamente, a literatura nacional sobre os impactos da remuneração dos administradores sobre a governança das companhias é esparsa. ${ }^{11}$

A crise do mercado acionário de 2000 e a crise financeira de 2008 fizeram ressurgir, especialmente nos EUA, o public outrage contra a remuneração percebida por administradores de grandes companhias. ${ }^{12}$ Ênfase foi dada à disparidade entre os valores percebidos pelos administradores de grandes companhias e aqueles percebidos pelo trabalhador médio das mesmas. ${ }^{13}$

\footnotetext{
10 "Art. 116. A sociedade anônima ou companhia será administrada por um ou mais diretores, acionistas ou não, residentes no país, escolhidos pela assembléia geral, que poderá destituí-los a todo tempo.

$\S 1^{\circ}$ Dos estatutos deverão constar:

[...]

b) o seu número e a maneira por que serão remunerados (artigo 134);

$[\ldots] "$

$\mathrm{O}$ art. 134 do Decreto-Lei n. 2.627/40, por sua vez, dispunha o seguinte: "Os estatutos sociais regularão o modo de dedução e as condições de pagamento das percentagens sobre os lucros líquidos que forem atribuídos, como remuneração, aos diretores. Qualquer que seja a forma de dedução adotada, os diretores não poderão receber percentagem alguma sobre os lucros líquidos verificados nos balanços em que não fôr distribuído aos acionistas um dividendo à razão de 6\% ao ano, no mínimo, observadas as disposições legais quanto às quotas que devam ser creditadas ao fundo de reserva."

${ }^{11}$ Este é um dos motivos que levou o Autor a recorrer de forma consistente à literatura estrangeira quando da abordagem de aspectos econômicos.

${ }^{12}$ Cf. BAINBRIDGE, Stephen M. Corporate Governance after the Financial Crisis. Nova Iorque: Oxford University Press, 2012. p. 110.

${ }^{13}$ REVELL, Janice. Mo' Money, Fewer Problems: is it a good idea to get rid of the $\$ 1$ million CEO pay ceiling? Fortune, 31 mar. 2003. Disponível em
} 
O presente trabalho não tem a pretensão de responder se o administrador de uma companhia merece uma remuneração muito maior que aquela percebida pelo trabalhador médio da mesma companhia. Muito embora essa seja uma discussão importante, ela se encontra fora da matéria do direito empresarial e o Autor a considera ampla demais e espinhosa para ser resolvida por um trabalho monográfico.

A preocupação deste trabalho, muito mais modesta, é com a estrutura e o valor das remunerações de administradores de companhias tomando-se a ótica do acionista, que, na visão do Autor, constitui o principal interesse da companhia. Mais especificamente, o presente trabalho preocupa-se com o disclosure das remunerações dos administradores das companhias abertas no Brasil enquanto mecanismo regulatório para melhorar a governança das companhias abertas, matéria de grande relevância e que vem sido debatida com grande veemência nos últimos anos.

O Autor não pode deixar de observar que em 02.03.2010 o IBEF ajuizou ação em face da CVM pedindo que fosse declarada a ilegalidade, em relação a seus associados, de dispositivos da ICVM 480 que determinam a divulgação, no Formulário de Referência, de determinados dados sobre a remuneração de administradores de companhias abertas. ${ }^{14} \mathrm{~A}$ discussão é de extrema relevância e será examinada no momento apropriado.

<http://money.cnn.com/magazines/fortune/fortune_archive/2003/03/31/340098/index.htm>. Acesso em 09 nov. 2013. A informação foi reproduzida no livro BEBCHUK, Lucian A.; FRIED, Jesse. Pay without Performance: the unfulfilled promise of executive compensation. Harvard University Press, 2004. p. 1.; e acabou sendo levada em consideração na elaboração do DoddFrank Act de 2010. Cf. House of Representatives of the United States of America. Report 110-88. p. 3. Este relatório fundamentou uma emenda ao projeto do Dodd-Frank Act de 2010 que acabou se tornando a seção 951. A sensação de desigualdade nele retratada, por sua vez, provavelmente deu origem à seção 953(b) do Dodd-Frank Act de 2010, analisada com mais detalhe no Capítulo 3. ${ }^{14} 5^{\mathrm{a}}$ Vara da Seção Judiciária do Rio de Janeiro. Ação Ordinária. Processo n. 2010.51.01.0028885. 
Como o leitor pode ter percebido, um dos pressupostos deste trabalho é que os acionistas representam o interesse principal da companhia. Além disso, pressupõe-se neste trabalho que os administradores de companhias têm interesses que não necessariamente coincidem com os interesses de seus acionistas, e que tal conflito de interesses gera, para a companhia, custos de agência (agency costs). Ele é uma iteração do problema principal agente (principal-agent problem) e uma decorrência da organização empresarial enquanto redutora de custos de transação (transaction costs).

O problema principal agente e a existência de custos de transação e custos de agência também constituem pressupostos teóricos deste trabalho e serão explicados de forma mais detida também no Segundo Capítulo.

No Terceiro Capítulo, este Autor apresentará, de maneira sistemática, o problema da remuneração dos administradores de companhias abertas visto por uma gama de autores estrangeiros (bem como alguns nacionais). Serão também comparadas as soluções regulatórias norte americanas e brasileiras. Considerações sobre maior regulação da matéria no Brasil serão feitas, especialmente no que tange ao mandatory disclosure. $^{15}$

Por fim, no terceiro capítulo, o Autor se concentrará sobre a questão da juridicidade do mandatory disclosure da remuneração de administradores de companhias abertas, operado recentemente pela ICVM

\footnotetext{
${ }^{15}$ Por mais interessante que seja um estudo sistematizado da matéria, o Autor não pretende entrar em detalhes a respeito da tutela do direito à informação pelo acionista na LSA. Luiz Antonio de Sampaio Campos observa que o dever de informação dos administradores de companhias abertas "se desdobra na obrigação de informação aos acionistas e na prestação de informação ao mercado." CAMPOS, Luiz Antonio de Sampaio. Deveres e Responsabilidades. In: LAMY FILHO, Alfredo; PEDREIRA, José Luiz Bulhões (coord.). Direito das Companhias. vol. 1. Rio de Janeiro: Forense, 2009. p. 1171. O Autor empreenderá um estudo em relação ao segundo caso ("prestação de informação ao mercado").
} 
480. Tal discussão tem como pano de fundo o poder normativo das agências reguladoras.

A conclusão deste trabalho será feita tanto dos pontos de vista jurídico e econômico, servindo tanto como análise do direito positivo brasileiro quanto como para considerações normativas. 


\section{Pressupostos teóricos}

Como destacado na Introdução deste trabalho, ele envolve necessariamente a noção de uma governança corporativa. $\mathrm{O}$ problema da remuneração dos administradores de companhias não pode ser explicado sem que o leitor partilhe de uma noção clara e definida de seu conteúdo. Logo, o Autor procurará despir, logo na primeira parte deste Capítulo, a expressão "governança corporativa” de seu caráter retórico.

Além disto, deve-se notar que o presente trabalho repousa sobre três principais pressupostos teóricos encontrados nas ciências econômicas e que recentemente têm transbordado para as ciências jurídicas. Trata-se (i) da existência de custos de transação na atividade econômica; (ii) da identificação do interesse da companhia com o interesse dos seus acionistas; e (iii) da existência de um problema principal-agente entre o acionista e o administrador. Abaixo os três pressupostos serão explicados de forma detida.

\subsection{Governança corporativa}

Desde o início das acaloradas discussões a respeito da governança corporativa, são inúmeras as definições dadas à expressão norte americana "corporate governance", cada uma com suas implicações e problemas. Christine Mallin aponta que o uso da expressão "governança corporativa" pela mídia especializada em finanças é um fenômeno novo, de aproximadamente vinte anos. ${ }^{16}$

De certa forma, pode-se dizer que o corporate governance movement teve início na década de 1970 nos EUA, paralelamente ao desenvolvimento

\footnotetext{
${ }^{16}$ MALLIN, Christine A. Corporate Governance. $4^{\mathrm{a}}$ ed. Nova Iorque: Oxford University Press, 2013. p. 15.
} 
de maiores estudos sobre o tema. Seligman, em The Transformation of Wall Street, relata que

"[o] debate de governança corporativa da década de 1970 efetivamente começou com os esforços de grupos de acionistas de interesse público de empregar as regras da SEC sobre pedidos públicos de procurações para publicizar sua oposição às políticas corporativas com a Guerra do Vietnã, com a segurança do trabalho e ambiental e com o emprego." 17

A falência da Penn Central, a maior companhia de ferrovias dos EUA, em junho de 1970, chamou a atenção da mídia. Nos dois anos que antecederam sua quebra, o conselho de administração da companhia aprovou o pagamento de dividendos no valor de mais de 100 milhões de dólares enquanto o passivo da companhia somente aumentava e o capital de giro deteriorava. A mídia e a literatura, após o evento, notaram que o caso do conselho de administração da Penn Central, na verdade, representava o caso de conselhos de administração de várias grandes companhias abertas norte americanas no pós-guerra. Segundo Seligman, este e outros casos de falências e fraudes corporativas sugeriram, na época, deficiências nos conselhos de administração norte americanos. ${ }^{18}$

Um estudo publicado em 1971 por Myles Mace, professor da Harvard Business School, concluía que os conselhos de administração das grandes ou médias companhias tinham perdido sua função de fiscalizar o diretor presidente. Eles não traçavam estratégias a serem seguidas nem tinham participação ativa na escolha do diretor presidente:

\footnotetext{
${ }^{17}$ Tradução livre. No original: "The 1970s' corporate governance debate effectively began with the efforts of public interest shareholder groups to employ SEC's proxy rules to publicize their opposition to corporate Vietnam War, environmental, occupational safety, and employment policies." SELIGMAN, Joel. Op. cit. p. 535. O autor relata que em 1968 o Medical Committee for Human Rights formulou petição ao Dow Chemical Group pedindo que ele parasse de fabricar napalm para uso contra seres humanos, bem como a Campaign GM, de 1970, em que se pediu à maior companhia dos EUA para que adotasse práticas mais socialmente responsáveis em transporte de massas, poluição aérea, segurança automobilística e emprego de minorias. Id., ibid. pp. 535-536.

${ }^{18}$ Id., ibid. pp. 536-537.
} 
"Tipicamente, diretores nem mesmo faziam perguntas sensíveis. Era considerado "descortês" ou uma quebra das "boas maneiras corporativas" membros do conselho de administração "questionarem" o diretor presidente da companhia." $" 19$

Em pesquisa inédita feita por William Ocasio e John Joseph, a primeira ocorrência, no periódico The New York Times, das palavras "corporate" e "governance" conjuntamente, com a primeira seguida pela segunda, se deu pela primeira vez em dezembro de 1972, em um artigo que versava sobre um aumento de ações judiciais movidas por acionistas e que enfatizava as responsabilidades dos membros do conselho de administração. ${ }^{20}$

Segundo Jorge Manuel Coutinho de Abreu, durante o escândalo de Watergate em 1976, investigações teriam revelado que várias companhias haviam financiado ilegalmente a campanha eleitoral de Richard Nixon e subornado governos estrangeiros. ${ }^{21}$ No último caso, seriam poucos os membros do conselho de administração cientes desta prática, enquanto quase todos os diretores estariam cientes da falsificação de registros da companhia necessária para o pagamento dos subornos. ${ }^{22}$ No mesmo ano, a expressão corporate governance apareceu pela primeira vez no Federal Register dos EUA - a publicação do governo federal norte americano contendo todas as normas emanadas por departamentos e agências do Poder Executivo daquele país. ${ }^{23}$ Até então, os investidores de companhias abertas, preocupados somente com a revenda das ações, não tinham nenhuma

\footnotetext{
${ }^{19}$ Tradução livre. No original: "Typically, directors did not even ask discerning questions. It was considered "discourteous" or a breach of "corporate manners" for directors to "challenge" the corporation's chief executive officers." Id., ibid. p. 537.

${ }^{20}$ OCASIO, William; JOSEPH, John. Cultural Adaptation and Institutional Change: the evolution of vocabularies of corporate governance, 1972-2003. Poetics, n. 33, 2005. p. 166.

${ }^{21}$ ABREU, Jorge Manuel Coutinho de. Op. cit. p. 10.

${ }^{22}$ CHEFFINS, Brian. The History of Corporate Governance. European Corporate Governance Institute, Law Working Paper n. 184/2012, jan. 2012. p. 3 Disponível em <http://ssrn.com/abstract=1975404>. Acesso em 08 out. 2013.

${ }^{23}$ OCASIO, William; JOSEPH, John. Op. cit. p. 167.
} 
preocupação com seus aspectos que não fossem o preço e os dividendos a elas atribuídos. ${ }^{24}$

Ainda em 1976, a SEC teria pressionado com sucesso a NYSE para que esta obrigasse as companhias nela listadas a instalar um comitê de auditoria (audit committee). ${ }^{25}$ Neste mesmo ano, Michael Jensen e William Meckling publicaram o influente artigo Theory of the Firm: managerial behavior, agency costs and ownership structure. ${ }^{26}$ Por fim, a ABA adotou o texto Corporate Director's Guidebook. ${ }^{27}$

Em 1978, parece ter prevalecido e se consolidado a ideia de que a maior parte dos membros do conselho de administração deveria ser independente, e que este órgão deveria ter a função de fiscalizar as atividades da companhia, especialmente por meio de comitês de auditoria, de remuneração e de nomeação. ${ }^{28}$

Segundo Brian Cheffins, a eleição de Ronald Reagan e a obtenção da maioria no Congresso norte americano pelo Partido Republicano teriam levado a uma forte reação contra o movimento iniciado na década de 1970, impondo freios a um impulso regulatório e de reforma à lei societária. Além

\footnotetext{
${ }^{24}$ LIVINGSTON, J.A. The American Stockholder, apud CHEFFINS, Brian. Op. cit. p. 3. ${ }^{25}$ Id., ibid. p. 3.

${ }^{26}$ JENSEN, Michael C.; MECKLING, William H. Theory of the Firm: managerial behavior, agency costs and ownership structure. Journal of Financial Economics, n. 4, vol. 3, out. 1976. Disponível em <hhtp://papers.ssrn.com/abstract=94043>. Acesso em 08 out. 2013.

${ }^{27}$ Ainda na literatura, Ralph Nader, Mark Green e Joel Seligman publicaram o livro Taming the Giant Corporation, que relatava o quanto a realidade política estaria dissociada do modelo legal das companhias norte americanas. Ao invés de servir no melhor interesse dos acionistas, os diretores das grandes companhias haviam estabelecido uma autocracia que tomava más decisões e que precisaria urgentemente ser fiscalizada por um conselho de administração mais forte. Melvin Eisenberg publicou o livro The Structure of the Corporation: a legal analysis, no qual defendia membros do conselho de administração mais independentes da diretoria e uma fiscalização efetiva da segunda pelos primeiros. CHEFFINS, Brian. Op. cit. p. 5.

${ }^{28}$ É a impressão do Autor. Cheffins relata que em 1978 a ALI se comprometeu a conduzir um projeto de governança corporativa e promoveu um congresso sobre o tema, em parceria com a NYSE e a ABA, ao qual compareceram diretores, acadêmicos, advogados e membros do governo. No mesmo ano, o Business Roundtable, grupo fundado em 1974 para representar as visões de 180 diretores presidentes de grandes companhias, fez um pronunciamento no qual reconheceu que conselhos de companhisa abertas deveria ser compostas por membros não pertencentes à administração e deveriam estabelecer comitês de auditoria, remuneração e nomeação dominados por membros independentes do conselho de administração. Id., ibid. p. 6.
} 
disso, o Tentative Draft No. 1, publicado pelo ALI em 1982, como resultado de seu projeto iniciado em 1978, recebeu forte oposição de doutrinadores e policy makers. ${ }^{29} \mathrm{Na}$ década de 1990, o texto final publicado pela ALI foi atingido após negociação. Suas recomendações lembravam muito o texto da lei à época e estavam muito mais moderados. ${ }^{30}$

Investidores institucionais, por sua vez, com cada vez maior participação nas companhias abertas norte americanas, ${ }^{31}$ e outras organizações teriam publicado códigos de boas práticas de governança corporativa em caráter recomendatório. ${ }^{32}$

O estouro da tech bubble, no início do século, que culminou com os casos Enron e Worldcom, levou à adoção, naquele país, do Sarbanes-Oxley Act, em 2002, classificado como "a maior reforma do direito societário norte-americano desde os anos 30". Jorge Manuel Coutinho de Abreu relata prática contábeis inflando receitas e lucros, fiscalização interna ineficiente, controle contábil externo ineficiente e práticas permissivas de conflitos de interesses entre administradores e companhia. ${ }^{33}$

Somente na década de 1990 o movimento se espalhou pela Europa, passando primeiro pelo RU. Escândalos financeiros e o fraco desempenho da administração de muitas empresas britânicas levou à confecção de

\footnotetext{
${ }^{29}$ Em sua grande parte, os autores que criticaram as primeiras formulações do corporate governance movement eram do movimento do Law and Economics. Brian Cheffins cita, a título de exemplo, Michael Jensen, Eugene Fama e Daniel Fischel. Id., ibid. pp. 7-9

${ }^{30} \mathrm{O}$ Principles of Corporate Governance: analysis and recommendations foi publicado em 1992. Id., ibid. p. 9.

${ }^{31}$ Em 1971, a SEC publicou estudo no qual conclui que 213 trusts de bancos, fundos de investimento, companhias de seguros e fundos de pensão detinham mais de $50 \%$ das ações ordinárias de várias companhias. Em 1978, investidores institucionais detinham 36,3\% de todas as ações ordinárias e preferenciais em circulação. Os dados são apresentados em SELIGMAN, Joel. Op. cit. p. 536.

${ }^{32}$ ABREU, Jorge Manuel Coutinho de. Op. cit. p. 10.

${ }^{33}$ Id., ibid. pp. 10-11.
} 
códigos de governança no RU, tendo sido o primeiro o influente Cadbury Report, publicado em 1992. ${ }^{34}$

A partir daí, no cenário europeu rapidamente se espalharam os códigos de boas práticas de governança corporativa, em sua maioria no RU - todos eles elaborados por entes privados e desprovidos de qualquer caráter vinculante.

O segundo código publicado no RU, de grande relevância para este trabalho, foi o Greenbury Report, de 1995. Christine Mallin comenta que a preocupação central deste código foi com o tamanho dos pacotes de remuneração dos diretores, e com seu disclosure incompleto e inconsistente nos relatórios anuais. As duas principais recomendações do Greenbury Report foram (i) a adoção de full disclosure dos elementos que compõem a remuneração dos administradores, e (ii) a adoção de práticas de remuneração que atrelassem a remuneração dos administradores à performance das companhias. $^{35}$

Em 1998, o Hampel Report, fruto das investigações do Hampel Committee, formado em 1995, reiterou ambos o Cadbury Report e o Greenbury Report. Enfatizou que o conselho de administração é responsável pelas relações com os stakeholders; mas é responsável perante os acionistas. No mesmo ano, os três códigos foram unificados no Combined Code. ${ }^{36}$

O RU ilustra bem os problemas associados à separação da propriedade e do controle nas grandes companhias abertas. ${ }^{37}$ Talvez devido a uma proximidade das características do mercado de capitais do RU com

\footnotetext{
${ }^{34}$ Id., ibid. p. 11.

${ }^{35}$ MALLIN, Christine. Op. cit. p. 29.

${ }^{36}$ Id., ibid. p. 30. Além destes primeiros códigos, no RU foram publicados vários outros códigos e relatórios, todos descritos por Christine Mallin. Id., ibid. pp. 30-37.

${ }^{37}$ Id., ibid. p. 27.
} 
as do mercado de capitais norte americano, foi fácil e extensa a proliferação do corporate governance movement para lá.

$\mathrm{O}$ alastramento do movimento do RU para a Europa continental teria sido rápido, diante da derrocada de várias empresas devido à má administração e à necessidade de se evitar escândalos financeiros. Da mesma forma que nos EUA, aos poucos os investidores institucionais e analistas financeiros também passaram a valorizar determinadas estruturas e práticas de governança e a promovê-las. ${ }^{38}$

Já no final da década de 1990 o movimento teria tomada dimensão global. Em 1999, a OCDE publicou seu próprio código de governança corporativa, os Principles of Corporate Governance. ${ }^{39}$

Finalmente, em 2003, a Comissão da União Europeia emitiu a Comunicação Modernising Company Law and Enhancing Corporate Governance in the European Union - A Plan to Move Forward, que apresenta um plano de ação para a reforma do direito societário europeu. A própria Comunicação enuncia seus objetivos, que são (i) o fortalecimento dos direitos dos acionistas e da proteção de terceiros, bem como (ii) o aumento da competitividade e eficiência das empresas. ${ }^{40}$

\footnotetext{
${ }^{38}$ ABREU, Jorge Manuel Coutinho de. Op. cit. pp. 11-12.

39 ORGANIZATION FOR ECONOMIC CO-OPERATION AND DEVELOPMENT. OECD Principles of Corporate Governance. Disponível em <http://www.oecd.org/daf/ca/oecdprinciplesofcorporategovernance.htm>. Acesso em 10 nov. 2013. Os Principles sofreram revisão em 2004.

${ }^{40}$ COMMISSION OF THE EUROPEAN COMMUNITIES. COM (2003) 284. Company Law and Enhancing Corporate Governance in the European Union: a plan to move forward. Bruxelas, 21 mai. 2003. Várias outras iniciativas por parte de investidores institucionais, de governos nacionais e de organizações internacionais em geral foram e tem sido tomadas ao desde o início do século $\mathrm{XX}$. De todo modo, interessa mais a este trabalho o surgimento do corporate governance movement e seu alastramento pelo mundo, de forma que este breve historical account sofrerá um corte temporal em 2003, com a COM (2003) 284.
} 
Especialmente por causa da existência de tantos códigos de governança corporativa, proliferou-se o uso da expressão. Vários conceitos diferentes foram empregados. ${ }^{41}$

O Autor, pelas razões abaixo, utilizará ao longo deste trabalho a definição que considera a de menor carga valorativa possível, bem como de maior concisão e simplicidade. Trata-se da definiç̧ão dada pelo Cadbury Report: "[g]overnança corporativa é o sistema por meio do qual sociedades são administradas e controladas."42

A neutralidade valorativa inerente a esta definição permite que se verifique em todas as sociedades a existência de governança corporativa. A discussão deixa de ser a respeito da existência da mesma e passa a ser a respeito de qual forma é mais adequada para cada companhia, à luz de determinados pressupostos. ${ }^{43}$

Desta forma, e em nome de maior clareza conceitual, toda vez que o Autor se deparou, na literatura, com uma proposição valorativa a respeito de governança corporativa, ela foi interpretada como uma proposição $a$ respeito da melhor prática de governança corporativa, e não como elemento integrante do conceito de governança corporativa.

É também importante destacar que tal sistema não é composto somente por normas jurídicas. Jorge Manuel Coutinho de Abreu afirma que

\footnotetext{
${ }^{41}$ Para um resumo dos vários significados já atribuídos à expressão por códigos de governança corporativa na Europa, ver WEIL, GOTSHALL \& MANGES. Comparative Study of Corporate Governance Codes Relevant to the European Union and its Member States, Final Report \& Annexes I-III. pp. 29-30.

${ }^{42}$ Tradução livre. No original: "Corporate governance is the system by which companies are directed and controlled." THE COMMITTEE ON THE FINANCIAL ASPECTS OF CORPORATE GOVERNANCE. Report of the Committe on the Financial Aspects of Corporate Governance, 01 dez. 1992.

${ }^{43}$ Interessante notar que temas de governança corporativa interessam também a tipos societários que não as sociedades anônimas, e mesmo a empresas não societárias. ABREU, Jorge Manuel Coutinho de. Op. cit. pp. 8-9. Na realidade, embora a doutrina tenha se concentrado no estudo das sociedades, pode-se, em tese, realizar um estudo da governança de qualquer forma de organização (associações, sindicatos, fundações, órgãos e agências governamentais, etc.).
} 
"[a] governação das sociedades não envolve somente regras (jurídicas ou não, vinculativas ou não). Envolve outros instrumentos (v. g., o mercado enquanto meio de controlo)." 44

O estudo da governança corporativa pode ser enxergado por outra ótica, mais econômica. ${ }^{45}$ Seria ela um desdobramento da Economia dos custos de transação (transaction-cost economics), ${ }^{46}$ dedicada a estudar como e porque as organizações e suas estruturas surgem e se mantêm. ${ }^{47} \mathrm{Em}$ outras palavras, ela é o estudo, sob a ótica contratual, de como as organizações privadas se ordenam. Nas palavras de Oliver Williamson, vencedor do Prêmio Nobel em Economia de 2009,

"[...] governança é o meio pelo qual se introduz ordem, assim mitigando o conflito e concretizando "o mais fundamental de todos os entendimentos na Economia”, o ganho mútuo por meio de trocas voluntárias.

[...]

Os atributos que definem uma estrutura de governança incluem intensidade dos incentivos, controle administrativo e regime de direito contratual.",48

“A Economia da governança, como descrito aqui, é principalmente um exercício de ordenamento privado bilateral, pelo qual eu entendo que partes imediatas de uma troca estão ativamente envolvidas no provimento de uma boa ordem e de acordos razoáveis." 49

O estudo deste trabalho segue principalmente um método econômico de analisar a governança corporativa. Envolve, portanto, as categorias

\footnotetext{
${ }^{44}$ Id., ibid. p. 8.

${ }^{45}$ Cheffins entende que o movimento acadêmico de governança corporativa seguiu dois caminhos distintos. A ortodoxia teria se inspirado em Berle e Means e concluído que a regulação seria a forma de proteger acionistas dispersos de seus administradores. A escola do Law and Economics teria proposto que o mercado já se impunha como um limite à atuação dos administradores. CHEFFINS, Brian. Op. cit. pp. 8-9.

${ }^{46}$ Iniciado, como será exposto abaixo, por Ronald Coase em 1937.

${ }^{47}$ WILLIAMSON, Oliver E. The Theory of the Firm as Governance Structure: from choice to contract. The Journal of Economic Perspectives, vol. 16, n. 3, 2002. p. 176.

${ }^{48}$ Tradução livre. No original: "[...] governance is the means by which to infuse order, thereby to mitigate conflict and to realize "the most fundamental of all understandings in economics," mutual gain from voluntary exchange.

[...]

The attributes that define a governance structure include incentive intensity, administrative control and the contract law regime." Id., ibid. p. 180.

${ }^{49}$ Id. The Economics of Governance. The American Economic Review, vol. 95, n. 2, Papers and Proceedings of the One Hundred Seventeenth Annual Meeting of the American Economic Association, mai. 2005. p. 1.
} 
próprias da ciência econômica dos últimos 70 anos, como "custos de transação", "custos de agência" e "contratualismo". A seguir, tais categorias serão analisadas brevemente.

\subsection{Os custos de transação}

A investigação dos fenômenos econômicos sob a ótica dos custos de transação é recente em termos históricos, mas, em comparação com a ciência econômica, não é nenhuma novidade.

Ronald Harry Coase, vencedor do Prêmio Nobel em Economia em 1991, foi provavelmente o primeiro teórico dos custos de transação. ${ }^{50} \mathrm{Em}$ 1937, ele publicou o artigo The Nature of the Firm, no qual procurou dar explicação ao fenômeno econômico da empresa ${ }^{51}$ e suas características artigo este que teve enorme repercussão em vários sentidos para as ciências econômicas e que será examinado em detalhe ao longo deste capítulo.

A primeira constatação de Coase a respeito das empresas é que a alocação de fatores de produção dentro delas não se dá por causa do sistema de preços, como se daria no mercado. ${ }^{52}$ Dentro de uma empresa, Coase argumenta, a alocação dos fatores de produção segue uma organização imprimida por quem a dirige. Daí surge o primeiro e mais importante

\footnotetext{
${ }^{50}$ No Brasil, este reconhecimento é feito em FORGIONI, Paula A. Teoria Geral dos Contratos Empresariais. $2^{\text {a }}$ ed. revista. São Paulo, Revista dos Tribunais, 2011. pp. 61-62. n. de rodapé 9.

${ }^{51}$ Deve-se notar que na teoria econômica, o vocábulo "empresa" ("firm") não tem o mesmo sentido construído pela doutrina juridical. Para este Autor, não há conexão conceitual, por exemplo, entre a noção econômica de empresa e aquela presente no art. 966 do Código Civil brasileiro (muito embora em vários casos possa haver conexões contingentes entre os dois conceitos). A definição econômica de empresa será explicada adiante. Além disto, a investigação econômica sobre a empresa na literatura empregada por este trabalho tem como pressuposto que uma das características do mercado é a alocação de recursos (ou de fatores de produção) por meio do mecanismo de preços.

${ }^{52}$ COASE, Ronald H. The Nature of the Firm. Economica, New Series, vol. 4, n. 16, p. 387, nov. 1937. O autor exemplifica seu argumento demonstrando que um funcionário dentro de uma empresa não é transferido de um departamento a outro por causa de uma mudança relativa dos preços, mas porque alguém o manda fazê-lo.
} 
caráter distintivo da empresa - ela é uma entidade que se sobrepõe ao mecanismo de preços. ${ }^{53}$

Contudo, se em uma economia de mercado a produção se dá, em tese, de forma ótima por meio do mecanismo de preços, perquirir o motivo do surgimento das empresas - ou seja, o motivo do surgimento de uma organização - ganha importância. ${ }^{54}$

Pode-se dizer que a investigação de Coase foi motivada, grosso modo, pela seguinte pergunta: “[...] por que há transações ocorrendo no mercado se por meio da organização se pode eliminar certos custos e de fato reduzir o custo de produção?"55 Sua tarefa seria a de "[...] tentar descobrir por que uma empresa surge em uma economia de trocas especializadas." 56

A razão, Coase argumenta, é a vantagem comparativa que se obtém com a organização dentro de uma empresa com a organização fora dela (por meio do mecanismo de preços). A organização dentro de uma empresa pode ser mas vantajosa que no sistema de mercado, desde que na primeira os custos de transação para fazê-lo sejam menores que no segundo. ${ }^{57}$

Ou seja, nas situações em que os custos de transação forem maiores dentro da empresa que no mercado, a organização se dará no mercado;

\footnotetext{
${ }^{53}$ Id., ibid. pp. 388-389.

${ }^{54}$ Id., ibid. p. 388.

${ }^{55}$ Tradução livre. No original: "[...] why, if by organizing one can eliminate certain costs and in fact reduce the cost of production, are there any market transactions at all?" Id., ibid. p. 394.

56 Tradução livre. No original: "[...] to attempt to discover why a firm emerges at all in a specialised exchange economy.” Id., ibid. p. 390.

57 Tradução livre. No original: "The main reason why it is profitable to establish a firm would seem to be that there is a cost of using the price mechanism." Id., ibid. p. 390.
} 
naquelas situações em que os custos de transação forem maiores no mercado que dentro da empresa, a organização se dará dentro da empresa. ${ }^{58}$

A síntese conclusiva de Coase é a seguinte:

"Na margem, o custo de organizar dentro da empresa será igual ou ao custo de organizar em outra empresa ou aos custos envolvidos em deixar a transação ser organizada pelo mecanismo de preços. ${ }^{, 59}$

Parecia cumprida a tarefa de Coase. Contudo, o método empregado pelo economista teve enorme repercussão e, anos mais tarde, seria reconhecido como verdadeira mudança de paradigma no pensamento econômico. Foi a primeira vez que os custos de transação explicaram, de forma sistemática, um fenômeno econômico. Até então a Economia era a ciência das escolhas dos agentes, não das transações. ${ }^{60}$

Muito embora a preocupação de Coase não tenha sido a de conceituar os custos de transação, ele acabou o fazendo de forma esparsa ao longo de seu artigo:

"A principal razão pela qual é lucrativo estabelecer uma empresa parece ser que existe um custo para usar o mecanismo de preços. O custo mais óbvio de 'organizar' a produção por meio do mecanismo de preços é o de descobrir quais são os preços aplicáveis. Esse custo pode ser reduzido mas não será eliminado pelo surgimento de especialistas que venderão tal informação. Os custos de

\footnotetext{
58 "We may sum up this section of the argument by saying that the operation of a market costs something and that, by forming an organisation and allowing some authority (an 'entrepreneur') to direct the resources, certain marketing costs are saved. The entrepreneur has to carry out his function at less cost, taking into account the fact that he may get factors of production at a lower price than the market transactions which he supersedes, because it is always possible to revert to the open market if he fails to do this." Id., ibid. p. 392. Neste trecho a ideia central da obra de Coase sobre o assunto fica mais clara. Em ALCHIAN, Armen; DEMSETZ, Harold. Production, Information Costs, and Economic Organization. The American Economic Review, vol. 62, n. 5, pp. 777-95, dez. 1972, as noções de autoridade e direção do empreendedor são rejeitadas e substituídas pela ideia de que a empresa é um contrato caracterizado por um agente contratual centralizado inserido em um processo de produção em equipe ("centralised contractual agent in a team productive process").

${ }^{59}$ Tradução livre. No original: "At the margin, the costs of organising within the firm will be equal either to the costs of organising in another firm or to the costs involved in leaving the transaction to be 'organised' by the price mechanism." COASE, Ronald H. Op. cit. p. 404

${ }^{60}$ WILLIAMSON, Oliver E. The theory of the Firm as Governance Structure: from choice to contract. p. 172.
} 
negociar e concluir um contrato em separado para cada transação que ocorre no mercado também deve ser levado em conta."

Em outras palavras, custos de transação são os custos incorridos pelos agentes para contratar no mercado. Podem envolver o acesso ao mercado, ao preço e às informações. Podem também envolver os custos de se negociar os contratos e de se contratar especialistas para fazê-lo.

\begin{abstract}
"Para realizar uma transação no mercado, é necessário descobrir quem é a pessoa com quem se quer negociar, informar as pessoas que se quer negociar e em quais condições, conduzir negociações até se chegar a uma barganha, minutar o contrato, realizar a inspeção necessária para se garantir que as condições do contrato estão sendo observadas e daí em diante."
\end{abstract}

São exatamente esses custos de transação que devem ser inferiores ao custo de organizar a atividade dentro da companhia para que sua existência seja justificada. Em síntese, este trabalho analisará, mais adiante, a estrutura de governança das companhias levando em consideração que elas surgiram como mecanismos para reduzir custos de transação. ${ }^{63}$

A mudança no método de investigação da economia (do "choice approach" para o "contract approach") levou ao surgimento de várias teorias sobre ele apoiadas. A "ciência dos contratos" deu origem a estudos sobre economia constitucional, alinhamento de incentivos e governança. $\mathrm{O}$ primeiro se distingue dos demais por ser uma ramificação de matriz pública da ciência dos contratos, enquanto os estudos sobre alinhamento de

\footnotetext{
${ }^{61}$ Tradução livre. No original: "The main reason why it is profitable to establish a firm would seem to be that there is a cost of using the price mechanism. The most obvious cost of 'organizing' production through the price mechanism is that of discovering what the relevant prices are. This cost may be reduced but will not be eliminated by the emergence of specialists who will sell this information. The costs of negotiating and concluding a separate contract for each exchange transaction which takes place on a market must also be taken into account." COASE, Ronald H. Op. cit. pp. 390-391.

${ }^{62}$ Tradução livre. No original: "In order to carry out a market transaction, it is necessary to discover who it is that one wishes to deal with, to inform people that one wishes to deal and on what terms, to conduct negotiations leading up to a bargain, to draw up the contract, to undertake the inspection needed to make sure that the terms of the contract are being observed and so on." COASE, R. H. The Firm, the Market, and the Law. Chicago: The University of Chicago Press, 1988. p. 114.

${ }^{63}$ WILLIAMSON, Oliver E. Op. cit. pp. 179-180.
} 
incentivos e governança são de matriz privada. Aquele refere-se ao alinhamento de interesses na negociação dos contratos; este à implementação destes contratos após sua existência. ${ }^{64}$ Este trabalho encontra suporte teórico especialmente no segundo.

Evidentemente, para um estudo de governança, é insuficiente constatar a existência de custos de transação, ou mesmo que a empresa surge em meio ao mercado como um mecanismo para reduzir tais custos de transação. Outros pressupostos associados a esta nova teoria devem entrar em jogo: a noção de racionalidade limitada (bounded rationality), oportunismo dos agentes e assimetria informacional (também referida por Williamson como idiosyncratic knowledge). ${ }^{65}$

\section{3. $O$ interesse social}

Um dos pressupostos teóricos deste estudo diz respeito ao interesse da companhia. $\mathrm{O}$ estabelecimento deste pressuposto é essencial para que se possa avaliar quem é afetado pelas práticas dos administradores, em qual medida (se em alguma), bem como qual o papel da remuneração dos administradores de companhias no alinhamento dos interesses entre eles e os interessados.

Nesta parte do trabalho, este Autor explicará brevemente sua posição a respeito do "interesse da companhia": a de que a companhia não possui interesse. Posteriormente, contingentemente abandonará sua posição (pelo motivo explicado abaixo) e adotará outra com base nas discussões doutrinárias sobre o direito positivo: a de que o interesse da companhia se identifica com o interesse de seus acionistas.

\footnotetext{
${ }^{64}$ Id., ibid. pp. 172-173.

${ }^{65}$ Id., ibid. p. 174. Para uma introdução aos conceitos de oportunismo e racionalidade limitada, cf. FORGIONI, Paula A. Op. cit. pp. 65-69.
} 


\title{
2.3.1. A companhia não possui interesse: corolário do contractarianism norte americano
}

As formulações em The Nature of the Firm foram extremamente relevantes para a ciência econômica moderna também porque deram início a estudos analíticos da empresa, que não mais enxergam a empresa como agente maximizador de utilidade, mas sim os indivíduos dentro dela como tais. Como o próprio Ronald Coase coloca: “A empresa, portanto, consiste no sistema de relações que vêm a existir quando a direção dos recursos depende de um empreendedor."66

Na visão deste Autor, o corolário lógico de perceber a empresa como um sistema de relações é reconhecer que estas relações se dão entre indivíduos que se conectam a este sistema. Furubotn e Pejovich notam que

\begin{abstract}
"[a] ótica dos direitos de propriedade pode ser entendida como uma tentativa de formular problemas de otimizações empiricamente significantes por meio da associação da função de utilidade com o tomador de decisão individual e então introduzindo conteúdo específico dentro da função. Dessa forma, torna-se possível considerar o comportamento do tomador de decisão dentro da empresa, órgão governamental, ou coletividade similar. A outra ideia chave na análise é que diferentes alocações de direitos de propriedade levam a diferentes estruturas de penalidades e recompensas e, portanto, decidem as escolhas abertas aos tomadores de decisões. Uma importante virada de perspectiva é evidente neste ponto. Ao invés de tratar a empresa como a unidade de análise e assumir que os interesses dos proprietários recebem atenção exclusiva por meio do processo de maximização de lucro, o modelo de maximização de utilidade enfatiza ajustes individuais ao ambiente econômico e procura explicar o comportamento da empresa e outras instituições através da observação de ações individuais dentro da organização." ${ }^{67}$
\end{abstract}

\footnotetext{
${ }^{66}$ Tradução livre. No original: "A firm, therefore, consists of the system of relationships which comes into existence when the direction of resources is dependent on an entrepreneur." COASE, Ronald H. The Nature of the Firm. p. 393. Trata-se do conceito econômico de "empresa" a que este Autor se referiu acima. Muito tempo depois foi percebido que a "teoria da empresa" ("theory of the firm") na Economia na realidade não era uma teoria sobre a empresa, mas uma teoria sobre os mercados nos quais as empresas são atores relevantes. Cf. JENSEN, Michael C.; MECKLING, William H. Op. cit. Cf. também DEMSETZ, Harold. The Structure of Ownership and the Theory of the Firm. Journal of Law \& Economics, n. 26, 1983. p. 377

${ }^{67}$ Tradução livre. No original: "[...] the property rights approach can be understood as an attempt to formulate empirically meaningful optimization problems by associating the utility function with the individual decision maker and then introducing specific content into the function. In this way, it becomes possible to consider the behavior of the decision maker within the firm, government bureau, or similar collective agency. The other key idea in the analysis is that different property
} 
Essa simples constatação acabou se tornando uma tese e ganhou nome na teoria de governança corporativa: a tese contratualista (contractarian thesis). ${ }^{68}$

Segundo ela, a empresa é entendida como um nexo, ou um núcleo, no qual indivíduos entram em várias relações contratuais. ${ }^{69}$ Dentro deste quadro teórico, perquirir sobre o interesse da companhia - comumente denominado "interesse social" ou o "interesse da companhia" - perde por completo seu sentido. ${ }^{70}$ A personalização (ou subjetivização) da empresa na companhia é uma ficção jurídica que se presta a facilitar sua compreensão e interação dentro do direito enquanto um patrimônio distinto e destinado a uma atividade econômica. Contudo, na visão deste Autor, não passa disto: uma ficção destinada a facilitar a compreensão e a interação social. É evidente que ela não pode ter interesse, pois não tem consciência da própria existência nem forma vontade. ${ }^{71}$ Quem têm interesse são os agentes que

rights assignments lead to different penalty-reward structures and, hence, decide the choices that are open to decision makers. An important shift of viewpoint is evident here. Instead of treating the firm as the unit of analysis and assuming that the owners' interests are given exclusive attention via the process of profit maximization, the utility maximizing model emphasizes individual adjustment to the economic environment and seeks to explain the behavior of the firm and other institutions by observing individual actions within the organization." FURUBOTN, Eirik G.; PEJOVICH, Svetozar. Property Rights and Economic Theory: a survey of recent literature. Journal of Economic Literature, n. 4, vol. 10, p. 1.138, dez. 1972. Por exemplo, em WILLIAMSON, Oliver E. Managerial Discretion and Business Behavior. The American Economic Review, vol. 53, n. 5, dez. 1963. pp. 1032-57 é feita uma análise detida de como os interesses dos administradores interferem no comportamento das empresas. O mesmo é empreendido em JENSEN, Michael C.; MECKLING, William H. Op. cit.

${ }^{68}$ Não se deve confundir aqui a tese contratualista (contractarian) da governança corporativa com a tese contratualista sobre a natureza da companhia, que será examinada posteriormente.

${ }^{69}$ Deve-se ressaltar que a expressão "nexus of contracts" foi cunhada por economistas; portanto, "contrato" aqui não tem um sentido jurídico. Segundo Eisenberg, dizer que a companhia é um nexo de contratos quer dizer que ela é um nexo de arranjos recíprocos (nexus of reciprocal arrangements). EISENBERG, Melvin A. The Conception that the Corporation is a Nexus of Contracts, and the Dual Nature of the Firm. Journal of Corporation Law, n. 24, 1998-1999. p. 822. ${ }^{70}$ JENSEN, Michael C.; MECKLING, William H. Op. cit. pp. 8-10.

${ }^{71}$ Georges Ripert descreve bem a diferença entre a persone morale e a persone naturel do direito francês: "Il ne faut pourtant pas oublier la différence fondamentale qui sépare la personnalité de la societé de celle des individus; la societé n'a pas d'âme; elle ne connait pas les sentiments affectifs; elle est mue par le seul interêt; elle n'a qu'un but, la conquête des bénéfices et elle apporte à cette conquête la supériorité que lui donne son impassibilité devant tous les sentiments moraux.” Em RIPERT, Georges. Traité Élémentaire de Droit Commercial. Paris: LGDJ, 1948. p. 233. 
nela se relacionam e atingem um equilíbrio - acionistas, administradores, empregados, fornecedores, etc.

Ao observar que a companhia é uma ficção jurídica, este Autor não pretende passar completamente ao largo ou reduzir a importância do debate acerca da natureza da pessoa jurídica. ${ }^{72}$ De fato, ele é de extrema relevância, mas não tem, na visão deste Autor, conexão com o que aqui se propõe. Isto porque não se questiona a existência da pessoa jurídica no mundo do direito - com efeito, se o direito atribui personalidade às sociedades, às associações e às fundações, não se questiona aqui que tal personalidade exista para o direito. Contudo, assim como as obrigações, os títulos de crédito e a própria personalidade atribuída aos seres humanos, é mero fenômeno jurídico. No mundo dos fatos, a atividade da empresa, desprovida da personalidade jurídica da companhia que a subjetiva no mundo jurídico, não é um ente só e indivisível, mas um conjunto de pessoas que atuam e tomam decisões com interesses às vezes convergentes, às vezes distintos. $^{73}$

Há, evidentemente, críticas a este entendimento. Lynn Stout, que se volta contra o que chama de "shareholder maximization ideology", atribui como um de seus fundamentos o entendimento de que as companhias não são reais. As companhias, para ela, são reais no sentido jurídico. ${ }^{74}$ Melvin

\footnotetext{
${ }^{72}$ Relatado, por exemplo, em PEREIRA, Caio Mário da Silva. Instituições de Direito Civil, vol I. $23^{\mathrm{a}}$ ed. revista e atualizada por Maria Celina Bodin de Moraes. Rio de Janeiro: Forense, 2009. pp. $259-266$

${ }^{73} \mathrm{O}$ seguinte trecho, da autoria de Thaller, ilustra como é possível considerar a sociedade uma ficção e ao mesmo tempo conceber sua atuação no mundo jurídico: " $C$ 'est une fiction: on imagine que la societé, comme telle, ne se confond pas avec les membres qui la composent. Lorsque deux ou plusieurs personnes se sont mises em societé, ce ne sont pas elles qui exercent le commerce. Il s'est interposé entre ces associes un être juridique, parfaitement séparable de leus personnes physiques. Il a un nom: la raison sociale ou la dénomination de l'entreprise. Il est anime d'une impulsion qui lui permet d'occuper la scéne du droit, d'acquérir des biens, de s'obliger, de plaider." THALLER, E. Traité Élémentaire de Droit Commercial. Paris: Rousseau, 1898. p. 153.

${ }^{74}$ STOUT, Lynn. The Shareholder Value Myth: how putting shareholders first harms investors, corporations, and the public. São Francisco: Berrett-Koehler, 2012. pp. 59-60.
} 
Eisenberg vai além e entende que esta coisa seja de propriedade dos acionistas. $^{75}$

O Autor se vê obrigado a discordar. Como já foi exposto, a observação de que a companhia produza efeitos externos e seja uma pessoa para o direito não significa que ela não possa ser decomposta nas pessoas que nela atuam e que verdadeiramente tomam as decisões e agem segundo determinados interesses. Por sua vez, a observação de Eisenberg de que os acionistas possuem a maioria dos consectários da propriedade exceto controle direto também é verdadeira, ${ }^{76}$ mas não significa que as ações conferem direitos de propriedade ao acionista. As ações são de sua propriedade, não a companhia ou seus ativos, e isso lhes confere, sobretudo, o direito de participar do resultado residual (residual claim) da companhia. ${ }^{77}$ Acionistas não podem, por exemplo, dispor do patrimônio da companhia. $^{78}$

A posição do Autor é defendida por Stephen Bainbridge, que entende que

\footnotetext{
"[a]s teorias contratualistas da companhia rejeitam a reificação da companhia salvo como um atalho semântico. Ao invés de ver a companhia como uma pessoa ou como uma entidade, doutrinadores contratualistas a vêem como um agregado de vários insumos agindo em conjunto para produzir bens ou serviços. Empregados fornecem trabalho. Financiadores fornecem capital. Acionistas inicialmente fornecem capital e subsequentemente suportam o risco das perdas $e$ monitoram o desempenho da administração. A administração monitora o desempenho dos empregados e coordena as atividades de todos os insumos da companhia. Portanto, a companhia não é uma coisa, mas sim um nexo de
}

\footnotetext{
75 "[I]f it makes little sense to distinguish those things that are inside the firm and those that are outside the firm, then there is no firm. Accordingly, at bottom the nexus-of-contracts conception is not a theory of the firm: It is a theory of why there are no firms." EISENBERG, Melvin A. Op. cit. p. 832.

${ }^{76}$ Id., ibid. p. 825 .

${ }^{77}$ BAINBRIDGE, Stephen M. The New Corporate Governance in Theory and Practice. p. 32.

${ }^{78}$ Id., ibid. p. 27.
} 
contratos implícitos e explícitos estabelecendo direitos e obrigações entre os vários insumos que constituem a companhia., 79

$\mathrm{O}$ autor, então, reconhece que os acionistas possuem direito sobre o resultado residual da companhia, mas não sobre a companhia em si:

\begin{abstract}
"Para que fique claro, os acionistas são proprietários do resultado residual dos ativos e rendimentos da companhia. Como veremos, a propriedade sobre esse resultado é a razão pela qual os acionistas são beneficiários dos deveres fiduciários dos administradores. A propriedade do resultado residual, contudo, não é o mesmo que a propriedade da companhia em si. Alguém é proprietário de cada fato de produção contratado pela companhia, mas ninguém é proprietário da totalidade. Ao invés disso, a companhia é um agregado de pessoas vinculadas por uma complexa rede de relações contratuais." $\$ 0$
\end{abstract}

No direito americano, Bainbridge defende que o nexo, o núcleo dos contratos da companhia é o conselho de administração (board of directors $).{ }^{81}$ No direito brasileiro a identificação deste nexo com um órgão específico da companhia é mais difícil, uma vez que (i) para a LSA a assembleia geral é o órgão supremo da companhia, podendo decidir "todos os negócios relativos ao objeto social" (art. 121 da LSA), ${ }^{82}$ e (ii) o direito brasileiro, como notam Erasmo Valladão e Fábio Konder Comparato, estabeleceu um regime dual, dando tratamento bastante diferente a

\footnotetext{
${ }^{79}$ Tradução livre. No original: "Contractarian theories of the corporation reject reification of the corporation except as a semantic shorthand. Instead of viewing the corporation either as a person or an entity, contractarian scholars view it as an aggregate of various inputs acting together to produce goods or services. Employees provide labor. Creditors provide debt capital. Shareholders initially provide equity capital and subsequently bear the risk of losses and monitor the performance of management. Management monitors the performance of employees and coordinates the activities of all the firm's inputs. Accordingly, the firm is not a thing, but rather a nexus of explicit and implicit contracts establishing rights and obligations among the various inputs making up the firm." Id., ibid. p. 28.

${ }^{80}$ Tradução livre. No original: "To be sure, shareholders own the residual claim in the corporation's assets and earnings. As we'll see, ownership of that claim is why shareholders are the beneficiaries of director fiduciary duties. Ownership of the residual claim, however, is not the same as ownership of the corporation itself. Someone owns each factor of production hired by the corporation, but no one owns the totality. Instead, the corporation is an aggregation of people bound together by a complex web of contractual relationships." Id., ibid. p. 32.

${ }^{81}$ Id., ibid. p. 34.

${ }^{82}$ PEDREIRA, José Luiz Bulhões; LAMY FILHO, Alfredo. Estrutura da Companhia. In: LAMY FILHO, Alfredo; PEDREIRA, José Luiz Bulhões (coord.). Op. cit. p. 805. Direito das Companhias. Rio de Janeiro: Forense, 2009. p. 805.
} 
companhias abertas e fechadas. ${ }^{83}$ Esta tarefa o Autor não pretende empreender neste trabalho.

Erasmo Valladão Azevedo e Novaes França, em sua obra Conflito de Interesses nas Assembléias de S.A., elucida que a noção de interesse coletivo repousa na distinção entre a mera soma de quaisquer interesses individuais de um grupo de pessoas e a soma dos interesses individuais desse mesmo grupo que digam respeito ao grupo. ${ }^{84} \mathrm{~A}$ distinção, na visão deste Autor, é perfeitamente válida - contudo, não afasta a constatação de que o interesse de uma coletividade emana dos indivíduos que a compõem.

Deve-se ressaltar, contudo, que a tese contratualista (contractarian thesis) não ganhou espaço no meio jurídico brasileiro. O art. 115 da Lei n. 6.404/1976 dispõe com clareza que "o acionista deve exercer o direito a voto no interesse da companhia". O art. 116, em seu parágrafo único, por sua vez, dispõe que

\footnotetext{
"[o] acionista controlador deve usar o poder com o fim de fazer a companhia realizar o seu objeto e cumprir sua função social, $e$ tem deveres $e$ responsabilidades para com os demais acionistas da empresa, os que nela trabalham e para com a comunidade em que atua, cujos direitos e interesses deve lealmente respeitar e atender."
}

A lei societária brasileira - com todo o apoio da doutrina e da jurisprudência - claramente acolheu a tese de que existe um interesse social. Mais, de que a companhia guarda uma função social com a comunidade em que se insere.

Por esta razão, a posição deste Autor, embora útil para considerações sobre política legislativa (e talvez até interessante para maiores estudos), é incompatível com o ordenamento jurídico brasileiro. Neste cenário, o Autor se vê obrigado a contingentemente abandonar sua posição e definir, para

\footnotetext{
${ }^{83}$ FRANÇA, Erasmo Valladão Azevedo e Novaes. Op. cit. pp. 48-49.

${ }^{84}$ Id., ibid. pp. 18-19.
} 
fins do presente trabalho, o que deverá ser entendido como "interesse da companhia”. É o que fará abaixo.

\subsubsection{Posição contingente: 0 interesse da companhia é o de seus acionistas}

O interesse da companhia é assunto que não deixa de ser polêmico e sobre o qual vários doutrinadores já travaram debates. Sua relevância é muito clara: de acordo com o art. 115 da Lei n. 6.404/76, o acionista deverá votar sempre no interesse da companhia. Isto equivale a dizer que não poderá votar contrariamente a tal interesse. ${ }^{85}$

As teses a respeito do interesse social dividem-se em contratualistas e institucionalistas. De forma resumida, estas defendem que "o interesse social abrange também interesses diversos dos interesses dos acionistas"; aquelas defendem que o interesse social resume-se "ao interesse coletivo destes". 86

Ripert relata em 1948 que a tese contratualista, que serviu bem ao liberalismo econômico, foi teve projeção no século XIX. Ela "encaixa maravilhosamente com a teoria geral da autonomia da vontade" e "autoriza, em nome da liberdade contratual, todas as combinações e todas as modificações das regras legais."

Isto ocorre porque a tese contratualista se concentra no ato criador da sociedade, que, segundo a tradição romana, é um contrato. No direito

\footnotetext{
${ }^{85}$ Conforme observa Marcelo Lamy Rego, a primeira parte do art. 115 da Lei n. 6.404/76 se restringe ao conteúdo do voto do acionista. Não há nenhum dispositivo legal que estenda o critério do interesse social à presença do acionista na assembleia, ou ao proferimento de um voto. $\mathrm{O}$ acionista é livre para comparecer em assembleia e votar. Caso o faça, aí sim deverá fazê-lo no interesse da companhia. REGO, Marcelo Lamy. Direito de Voto. In: LAMY FILHO, Alfredo; PEDREIRA, José Luiz Bulhões (coord.). Op. cit. p. 402.

${ }^{86}$ FRANÇA, Erasmo Valladão Azevedo e Novaes. Op. cit. p. 22.

${ }^{87}$ Tradução livre. No original: "[...] car elle cadrait merveilleusement avec la théorie générale de l'autonomie de la volonté et aussi parce qu'elle autorisait, au nom de la liberté contractuelle. toutes les combinations et toutes les modifications des règles légales." RIPERT, Georges. Op. cit. p. 229.
} 
francês, a este contrato, que regula as relações entre os sócios, seria permitido modificar qualquer regra legal salvo aquelas de ordem pública. ${ }^{88}$ O consenso na criação da sociedade é essencial: "[n] ão há sentido na sociedade sem a vontade de se unir." 89

Ripert também explica, em outra obra, o posicionamento do Judiciário francês a respeito das sociedades anônimas:

"A jurisprudência chamada a estatuir sôbre a validade das cláusulas insertas nos estatutos ou as decisões das assembléias gerais é, em regra liberal: autoriza a emissão das ações com ágio e as comissões dos bancos sôbre o montante das entradas, a amortização do capital pela emissão de ações de gôzo, a criação de ações gratuitas em representação de reservas, a conversão em ações de obrigações e partes beneficiárias, a estipulação de juros fixos em proveito do acionista, a criação de obrigações de renda variável, as restrições à negociação dos títulos. $" 90$

Fábio Konder Comparato comentou, em 1975, que no Brasil a posição contratualista encontrava lastro em certos dispositivos do Decreto n. 2.627/40, que exigia a unanimidade para determinadas deliberações dos acionistas. ${ }^{91}$

A tese contratual permaneceu incólume até o início do século $\mathrm{XX}$, quando foi alvo de ataque por autores que se propuseram a apontar suas deficiências e seu destacamento da realidade. Como relatam Bulhões Pedreira e Lamy Filho, no final do século XIX alguns autores alemães sentiram uma incompatibilidade entre a noção clássica de contrato e a

\footnotetext{
${ }^{88}$ Id., ibid. p. 229. Um exemplo perfeito da noção contratualista da sociedade pode ser encontrada na abertura do tomo terceiro do tratado de direito comercial escrito por Pardessus, publicado pela primeira vez em 1815: "Le mot societé a deux sens dans le langage du commerce. Quelquefois il sert à exprimer la convention par laquelle plusieurs personnes s'obligent à conferer quelquer objets, ou à faire quelque chose, en commun pour en obtenir un profit licite. Quelquefois il signifie le corps moral formé par la réunion de ces personnes." Em PARDESSUS, Jean-Marie. Cours de Droit Commercial, t. 3. Paris: Garnery, 1815. p. 1.

${ }^{89}$ Tradução livre. No original: "Il n'y a point de société sans volonté de s'unir." Id., ibid. p. 4.

${ }^{90}$ RIPERT, Georges. Aspectos Jurídicos do Capitalismo Moderno, trad. por Gilda G. de Azevedo. Rio de Janeiro: Freitas Bastos, 1951. pp. 73-4.

${ }^{91}$ COMPARATO, Fábio Konder. O Poder de Controle na Sociedade Anônima. São Paulo: Revista dos Tribunais, 1975. p. 36.
} 
"[...] constituição das sociedades por ações mediante oferta pública, assinatura dos boletins de subscrição e deliberação dos subscritores em assembléia geral, quando as declarações de vontade se sucedem no tempo e cada subscritor pode desconhecer a maioria dos demais." 92

As objeções à classificação da companhia como contrato por este motivo acabaram se reduzindo com a difusão, no século $\mathrm{XX}$, dos contratos de massa. ${ }^{93}$ Neste século, entretanto, surgiram as teses institucionalistas.

Relata Erasmo Valladão que Walther Rathenau publicou em 1917 a obra Von Aktienwesen (Eine geschaeftliche Betrachtung), na qual argumentou que a grande empresa não era mais "uma organização do direito privado, mas um fator da economia nacional, a serviço de interesses públicos." A sociedade anônima tomada como parâmetro pela lei da época não existia mais. A lei societária regulava um fenômeno completamente distinto daquele para o qual fora idealizada. ${ }^{94}$

Rathenau também argumentou que desaparecera a figura do grande acionista; que a grande empresa era caracterizada por dar vida a outras empresas (daí a noção de grupo); e que a grande empresa assumiu a responsabilidade pela pesquisa técnico-científica. Diante de todas essas circunstâncias, propugnou uma "visão publicística da grande empresa", com o "fortalecimento dos poderes da administração", que passaria a dirigir autonomamente a empresa. Esta deveria "perseguir os seus próprios fins". 95

A teoria de Rathenau teria sido seguida pela teoria da empresa em si (unternehmen an sich), que também tinha uma visão publicística da empresa, segundo a qual, como resume Erasmo Valladão: (i) os interesses dos trabalhadores, dos consumidores e da economia nacional também são merecedores de tutela legal, (ii) a empresa é dotada de um interesse próprio,

\footnotetext{
92 PEDREIRA, José Luiz Bulhões; LAMY FILHO, Alfredo. Conceito e Natureza. In: LAMY FILHO, Alfredo; PEDREIRA, José Luiz Bulhões (coord.). Op. cit. p. 80.

${ }^{93}$ Id., ibid. p. 81.

${ }^{94}$ FRANÇA, Erasmo Valladão Azevedo e Novaes. Op. cit. p. 22.

95 Id., ibid. p. 23.
} 
dirigido não à produção de lucros, mas à melhoria de sua própria eficiência, (iii) o controle da empresa tende a ser confiado a uma administração estável e coesa, e (iv) os direitos dos acionistas são reduzidos em proveito do superior interesse da empresa, em relação à qual os primeiros têm um dever de fidelidade. ${ }^{96}$

Tal teoria, a despeito de críticas, teria ganhado espaço na Alemanha nazista, mediante a edição da Aktiengesetz de 1937, que consagrou a independência e autonomia da administração frente aos sócios e estabeleceu a subordinação da sociedade ao Ministro da Economia, que podia dissolvêla caso entendesse que suas atividades punham em perigo o bem público. ${ }^{97}$

Não se deve confundir essa teoria com a teoria da pessoa em si (person an sich), segundo a qual a sociedade, por ser pessoa jurídica, tem um interesse próprio. Aqui não há reconhecimento de interesses públicos, externos à sociedade, muito menos a outorga de sua tutela a seus administradores. ${ }^{98}$

A teoria do direito da empresa acionária, por sua vez,

"[...] negava que a empresa fosse titular de interesses, mas via confluir na empresa sujeitos diversos, titulares de um interesse comum, ou seja, além dos acionistas, os membros da administração, os credores e os trabalhadores e seus dependentes." ${ }^{99}$

Esta teoria não identificava um núcleo de interesses nos acionistas, ou na companhia, ou mesmo em um elemento fora dela (como a economia nacional). Antes, cada sujeito que atuava no seio da companhia tinha um interesse - e todos tinham um interesse comum.

\footnotetext{
${ }^{96}$ Id., ibid. p. 24.

${ }^{97}$ Id., ibid. p. 25-26.

${ }^{98}$ Id., ibid. p. 27.

${ }^{99}$ Id., ibid. p. 28.
} 
Por fim, o jurista francês Hauriou já chegou a considerar a empresa uma instituição - daí o nome "teoria da instituição" - sem, contudo, definir precisamente em que constituiria essa instituição. Seria a instituição a categoria jurídica da estabilidade, da duração. ${ }^{100}$ A elevação da empresa a esta categoria levou a conclusão próxima à da teoria da empresa em si: a de que o interesse social não se identifica com o interesse dos acionistas. ${ }^{101}$

Segundo Rubens Requião, são três os elementos de toda instituição corporativa: (i) "a idéia da obra a realizar em um grupo social", (ii) "o poder organizado posto a serviço desta idéia para sua realização", e (iii) "as manifestações de comunhão que se produzem no grupo social a respeito da idéia e de sua realização."

No Brasil tanto a tese contratualista quanto a institucionalista ganharam adeptos.

Erasmo Valladão comenta que a companhia, no direito brasileiro, teria um caráter marcadamente institucionalista, uma vez que o art. 116, parágrafo único, estatui o dever do acionista controlador de dirigir a companhia de forma a fazê-la cumprir sua função social. ${ }^{103}$ Erasmo Valladão clama que não se ignore $o$ fato de que trabalhadores, consumidores e potenciais investidores dependem da atividade das companhias. $^{104} \mathrm{O}$ caráter institucionalista seria ainda mais forte nas

\footnotetext{
${ }^{100}$ Id., ibid. p. 30. Como a noção de instituição teria sido transplantada do direito público para o direito privado, cabe expor aqui a formulação de Hauriou sobre a instituição: "Elle comporte les éléments suivants: $1^{\circ}$ Un pouvoir de commandement dans le groupe; $2^{\circ}$ Une obligation de sujétion coutumière émanant de la majorité des membres du groupe par laquelle le pouvoir de commandement est accepté; $3^{\circ}$ Une idée d'entreprise relative à la conduite du groupe, laquelle, dans l État, devient l'idée de la création d'une chose publique superposée à la chose privée (res publica)." HAURIOU, Maurice. Précis Élémentaire de Droit Constitutionnel. $10^{\mathrm{a}}$ ed. Paris: Sirey, 1930. pp. 21-22.

101 Id., ibid. p. 32.

${ }^{102}$ REQUIÃO, Rubens. A Sociedade Anônima como "Intituição". Revista de Direito Mercantil, Industrial, Econômico e Financeiro, ano XIV, n. 18, 1975. p. 27

${ }^{103}$ FRANÇA, Erasmo Valladão Azevedo e Novaes. Conflito de Interesses nas Assembléias de S.A. São Paulo: Malheiros, 1993. pp. 56-57.

${ }^{104}$ Id., ibid. p. 49.
} 
companhias abertas, uma vez que ela está sujeita a um regime jurídico muito mais regulado (pela própria LSA, por atos normativos emanados pela CVM, por regulamentos de bolsas de valores, etc.). Por outro lado, o autor não quer deixar de enxergar na companhia uma natureza contratual, que se presta a regular as relações entre os sócios. ${ }^{105}$

Bulhões Pedreira e Lamy Filho, antes de mergulhar na discussão, diferenciam as noções sociológica e jurídica de instituição. Ao comentar a concepção sociológica, procuram evidenciar seu caráter distintivo:

"A característica básica da organização institucionalizada é a sua continuidade independentemente dos indivíduos que, a cada momento, nela exercem funções, $e$ por isso tem como antítese a própria estrutura personalizada, no sentido de que existe na dependência da vontade dos indivíduos que desempenham seus papéis, como ocorre na microempresa com empresário individual e nas pequenas sociedades de pessoas." 106

O contrato de sociedade daria origem a uma instituição, um organismo que tem por fim a busca de interesse intermediário entre o dos indivíduos e o do Estado. ${ }^{107}$

Os autores observam, com acerto, que a corrente institucionalista não fornece ferramentas de interpretação da LSA, e que não conhecem até hoje regime jurídico formulado com base numa concepção sociológica institucionalista de empresa. $^{108}$

\footnotetext{
${ }^{105}$ Id., ibid. pp. 55-56.

${ }^{106}$ PEDREIRA, José Luiz Bulhões; LAMY FILHO, Alfredo. Conceito e Natureza. In: LAMY

FILHO, Alfredo; PEDREIRA, José Luiz Bulhões (coord.). Op. cit. p. 86.

${ }^{107}$ Id., ibid. p. 85.

${ }^{108}$ Id., ibid. pp. 86-87. A constatação, por via da teoria jurídica do contratualismo, de que o interesse da companhia é o de seus acionistas, também poderia ser alcançada pela análise econômica inicialmente proposta (e abandonada contingentemente) pelo Autor. Isto ocorre porque, de acordo com a corrente mais predominante no Law and Economics, os acionistas são os únicos integrantes da companhia com direito a um resultado meramente residual, variável e ex post sobre os ativos e rendimentos da companhia. Em contraste com os empregados, por exemplo, eles são aqueles que têm o maior interesse em maximizar a lucratividade da companhia. A razão pode ser resumida na seguinte colocação: "The gains and losses from abnormally good or bad performance are the lot of the shareholders, whose claims stand last in line." EASTERBROOK, Frank H.;
} 
Outra coisa completamente distinta, para eles, seria a concepção da companhia enquanto instituição jurídica. Enquanto no contrato as partes têm a liberdade de estipular livremente seus direitos e obrigações (respeitada a ordem pública), na instituição a liberdade individual somente faz nascer os direitos e obrigações já pré-concebidos na norma legal, sem possibilidade de alteração. ${ }^{109}$

Desta forma, parece que o argumento de Erasmo Valladão pode ser bifurcado e respondido de forma analítica. Bulhões Pedreira e Lamy Filho atacam sua posição (embora não haja qualquer indicação de que estejam respondendo ao argumento de Erasmo Valladão especificamente). Entendem que o art. 116, parágrafo único, da LSA traduz o mero reconhecimento de que a companhia exerce atividade empresária e, portanto, emprega e coordena fatores de produção para produzir e fazer circular bens e serviços pela economia. Além disto, somente o acionista controlador e os administradores estão adstritos ao dever de observar outros interesses que não o da companhia - pela redação do art. 116, acionistas não controladores restam desobrigados de fazê-lo. Entendem eles, por fim, que não se precisa recorrer à teoria institucionalista da empresa para cobrar da companhia e de seus controladores e administradores responsabilidade social. $^{110}$

No que tange às colocações de Erasmo Valladão de que é crescente o número de normas de ordem pública que restringem a autonomia da vontade na disciplina societária, especialmente nas companhias abertas, os autores lembram que, no direito positivo brasileiro, a companhia é constituída por subscritores de ações, que definem os direitos de participação dos acionistas, mediante fixação do número, espécies e classes

FISCHEL, Daniel R. The Economic Structure of Corporate Law. pp. 67-70. Cf. também BAINBRIDGE, Stephen. Op. cit. pp. 50-51.

${ }^{109}$ PEDREIRA, José Luiz Bulhões; LAMY FILHO, Alfredo. Conceito e Natureza. In: LAMY FILHO, Alfredo; PEDREIRA, José Luiz Bulhões (coord.). Op. cit. p. 88.

${ }^{110}$ Id., ibid. p. 90. 
das ações, as vantagens das ações preferenciais e os limites à circulação de tais títulos. Além disso, os acionistas têm o poder de eleger e destituir os administradores, de fixar-lhes a remuneração, de constituir e extinguir o conselho de administração, bem como de alterar o estatuto social. ${ }^{111}$ Arrematam os autores com a seguinte conclusão:

"[a] participação da vontade das partes na definição do conteúdo do contrato de companhia é incompatível com a proposição de que ela nasce de simples ato de adesão a estatuto legal que regula - sem qualquer lugar para a autonomia da vontade - todos os direitos e obrigações de determinadas situações jurídicas." 112

O argumento de Lamy Filho e Bulhões Pedreira parece ser irrebatível. Com efeito, a natureza da sociedade e seu interesse dependem fortemente do direito positivo de cada país.

$\mathrm{Na}$ visão deste Autor, em que pesem os argumentos contrários, de fato o recurso à teoria institucionalista não é necessário para imputar à companhia responsabilidade social. Os compromissos desta com a comunidade encontram-se regulados, no ordenamento brasileiro, pelos direitos do trabalho, previdenciário, consumerista e regulatório - não pelo direito societário.

Evidente que, especialmente nas últimas décadas, vários aspectos da companhia tem sido regulados de forma pormenorizada - a ordem pública tem avançado, tomando espaço antes pertencente à autonomia da vontade, notadamente na proteção ao acionista minoritário e ao potencial investidor. Contudo, ela parte de um reconhecimento de que o contrato de sociedade produz efeitos (ainda que não jurídicos) em relação a terceiros, algo que se pode e deve reconhecer em relação a qualquer tipo contratual. De fato, no nosso regime, a maior parte dos aspectos da companhia é deixada à livre decisão pelos seus fundadores e pode ser posteriormente alterada pelos

\footnotetext{
${ }^{111}$ Id., ibid. p. 89.

112 Id., ibid. p. 89.
} 
acionistas reunidos em assembleia. Sobretudo, jamais se deve perder de vista que qualquer companhia no direito brasileiro - salvo as sociedades de economia mista - nasce por vontade exclusiva dos acionistas fundadores reunidos em assembleia, e pela vontade da maioria dos acionistas ela pode deixar de existir. ${ }^{113}$

Uma vez que este trabalho se funda sobre a noção de que existe um interesse social somente porque a lei societária assim determina, nada mais adequado, por coerência, que este trabalho adote a mesma concepção de interesse social que a lei societária adotou. Na visão deste Autor, trata-se da concepção contratualista.

\subsection{O problema principal-agente}

A teoria da agência (agency theory) foi desenvolvida em conjunto por economistas norte americanos no final de década de 1960 no âmbito da economia industrial e dos estudos organizacionais. ${ }^{114}$

Jensen e Meckling, no primeiro estudo que expressa e sistematicamente aplicou a teoria da agência à relação entre acionistas e administradores de companhias, definiram a relação de agência como

\footnotetext{
113 “[...] a legislação brasileira, desde o fim do século XIX, regula a companhia como contrato de sociedade comercial, embora sujeito a muitas normas legais cogentes, o que é reafirmado pelo novo Código Civil, que inclui a companhia entre os tipos de sociedade empresária (arts. 1.088 e 1.089)." Id., ibid. p. 92.

${ }^{114}$ Evidentemente, a percepção e o tratamento destes problemas se dera muito antes, mas não de forma sistemática nem sob a rubrica de "teoria da agência". A este respeito, é perfeitamente possível enxergar Berle e Means, bem como Adam Smith, como predecessores destes estudos. STOUT, Lynn. Op. cit. p. 34; EISENHARDT, Kathleen. Agency Theory: an assessment and review. The Academy of Management Review, vol. 14, n. 1, jan. 1989. p. 58; e GORGA, Érica. Direito Societário Atual. Rio de Janeiro: Elsevier, 2013. p. 53 concordam a respeito do pioneirismo de Jensen e Meckling ao incorporar à teoria da agência o problema principal-agente e aplicá-lo à relação entre acionistas e administradores. Com a exceção de Lynn Stout, todas aceitam o modelo Jensen-Meckling e constroem suas teses sobre ele. Em FAMA, Eugene. Agency Problems and the Theory of the Firm. Journal of Political Economy, vol. 88, n. 2, abr. 1980. pp. 288-289 os modelos Jensen-Meckling e Alchian-Demsetz são colocados na literatura econômica dos "property rights". Em ROSS, Stephen A. The Economic Theory of Agency: the principal's problem. The American Economic Review, vol. 63, n. 2, Papers and Proceedings of the Eighty-fifth Annual Meeting of the American Economic Association, mai. 1973. pp. 134-139 é possível encontrar uma tentativa de formulação do problema. O mesmo em WILSON, Robert. The Theory of Syndicates. Econometrica, vol. 36, n. 1, jan. 1968. pp. 119-132.
} 
"[...] um contrato sob o qual uma ou mais pessoas (o(s) principal(is)) obrigam outra pessoa (o agente) para prestar algum serviço em seu nome que envolve a delegação de alguma autoridade ao agente para a tomada de decisões." 115

O problema desta relação de agência, segundo eles, é que, se ambas as partes deste contrato forem maximizadoras de utilidade, ${ }^{116}$ há boas razões para se acreditar que o agente nem sempre agirá no melhor interesse do principal. Esta é, de forma sintética, a definição do problema principalagente (principal-agent problem), que tem ocupado o centro das discussões a respeito da governança corporativa.

A ilustração que Jensen e Meckling utilizam para apresentar sua teoria de que administradores e acionistas têm curvas de utilidade distintas é a seguinte. Imagine-se que uma pessoa seja, ao mesmo tempo, administrador e detentor de $100 \%$ do capital de uma companhia. Esta pessoa tomará as decisões operacionais, enquanto administradora, de forma a maximizar sua utilidade. Tais decisões levarão em contra não somente os benefícios pecuniários como os benefícios não pecuniários, como localização do escritório, o nível de disciplina dos subordinados, relações pessoais, etc. $\mathrm{O}$ equilíbrio entre benefícios pecuniários e não pecuniários é atingido quando a utilidade marginal derivada de um dólar adicional nas despesas é igual para todos os itens não pecuniários e igual à utilidade marginal derivada de um dólar adicional em poder de compra (após impostos). ${ }^{117}$ Imagine-se agora que o administrador cede 5\% do capital de

\footnotetext{
115 Tradução livre. No original: “[...] a contract under which one or more persons (the principal(s)) engage another person (the agent) to perform some service on their behalf which involves delegating some decision making authority to the agent." JENSEN, Michael C.; MECKLING, William H. Op. cit. p. 309.

${ }^{116}$ Em sua tentativa de sistematização da teoria da agência, EISENHARDT, Kathleen. Op. cit. p. 59 identifica como pressupostos humanos (human assumptions) dessa teoria o interesse próprio, a racionalidade limitada e a aversão ao risco. Um paralelo muito forte pode ser traçado entre a teoria da agência e a teoria dos custos de transação. Segundo Oliver Williamson, "[t] he theory of the firm as governance structure is an effort to infuse operational content. Transaction cost economizing is the unifying concept." WILLIAMSON, Oliver E. The Theory of the Firm as Governance Structure: from choice to contract. p. 180.

${ }^{117}$ No original: "The optimum mix (in the absence of taxes) of the various pecuniary and nonpecuniary benefits is achieved when the marginal utility derived from an additional dollar of expenditure (measured net of any productive effects) is equal for each non-pecuniary item and
} 
sua companhia a um terceiro. $\mathrm{O}$ administrador somente realizará despesas até a utilidade marginal derivada de benefícios não pecuniários ser igual à utilidade marginal derivada de 95 centavos de dólar adicionais em poder de compra.

Em outras palavras, quando o administrador é também detentor de 100\% do capital da companhia, somente maximizará sua utilidade (isto é, utilizará de forma ótima o dinheiro investido na companhia) se a utilidade de um dólar gasto em despesas for igual à utilidade do poder de compra garantido por um dólar. Quando o administrador é detentor de 95\% do capital da companha, o maximização de utilidade se dá em um patamar mais baixo: ele utilizará de forma ótima o dinheiro investido na companhia mesmo quando a utilidade de um dólar gasto for igual à utilidade do poder de compra de somente 95 centavos de dólar. ${ }^{118}$

O problema principal-agente traz custos para as duas partes envolvidas. $\mathrm{O}$ principal, em vários casos, limita a divergência na atuação do agente fixando incentivos para o mesmo e monitorando suas atividades; o agente, por sua vez, é obrigado a prestar garantias de que não irá agir em detrimento do principal.

É possível, por meio do emprego destes mecanismos, alinhar os interesses do agente com os do principal. Contudo, tal alinhamento, por força da natural divergência entre interesses, geralmente será impossível sem se incorrer em custos. Na maior parte das situações, portanto, o

equal to the marginal utility derived from an additional dollar of after-tax purchasing power (wealth).” Em JENSEN, Michael C.; MECKLING, William H. Op. cit. p. 11.

118 Este exemplo é uma adaptação daquele fornecido em JENSEN, Michael C.; MECKLING, William H. Op. cit. pp. 11-12. As implicações deste raciocínio na precificação das ações das companhias seriam enormes. No exemplo fornecido, o detentor de 5\% do capital da companhia, como será explicado abaixo, incorre em custos de monitoramento (monitoring costs) para monitorar as atividades do administrador e alinhar seus interesses. Um potencial comprador desta participação de 5\% irá levar em consideração que também incorrerá neste custo e, com base em sua melhor estimativa, tentará descontar este custo do preço de compra das ações ao negociar com o vendedor. Id., ibid. pp.11-12. 
principal incorre em custos de monitoramento (monitoring costs) e o agente incorre em custos com a prestação de garantias (bonding costs). Há também uma parte da divergência de interesses que não é eliminada e que acarreta detrimento ao principal - a expressão econômica de detrimento é a perda residual (residual loss). A soma destes três componentes constitui os custos de agência (agency costs). ${ }^{119}$

A literatura norte americana parece ter consolidado as noções de problema principal-agente e custos de agência. Mais de uma década depois, Kathleen Eisenhardt, na tentativa de sistematizar a discussão a respeito do assunto, escreveu:

"[a] teoria da agência se preocupa em resolver dois problemas que podem ocorrer em relações de agência. O primeiro é o problema de agência que emerge quando (a) os desejos ou objetivos do principal e do agente entram em conflito $e$ (b) é difícil ou caro para o principal verificar o que o agente está de fato fazendo." $" 120$

Além do problema de agência, a teoria da agência também se ocupou de estudar o problema da alocação do risco (problem of risk sharing). Nele, o principal e o agente podem preferir diferentes ações devido a preferências diferentes pelo risco. ${ }^{121}$ É comumente afirmado que os administradores normalmente têm um apetite menor pelo risco que os acionistas. Isto, em tese, é explicado pelo fato de que, naturalmente, os acionistas têm direito ao resultado residual da companhia, enquanto os administradores não, bem como pelo fato de que, enquanto acionistas possuem ativos de grande

\footnotetext{
${ }^{119}$ Id., ibid. pp. 5-6.

${ }^{120}$ Tradução livre. No original: "Agency theory is concerned with resolving two problems that can occur in agency relationships. The first is the agency problem that arises when (a) the desires or goals of the principal and agent conflict and $(b)$ it is difficult or expensive for the principal to verify what the agent is actually doing." EISENHARDT, Kathleen M. Op. cit. p. 58. No Brasil, cf. GORGA, Érica. Op. cit. pp. 53-54.

${ }^{121}$ EISENHARDT, Kathleen M. Op. cit. p. 58.
} 
liquidez, administradores possuem ativos de valor específico para a empresa (firm-specific assets). ${ }^{122}$

Seguindo este raciocínio, os acionistas preferirão a adoção de estratégias que maximizem o resultado residual (residual claim) - que é o resultado da companhia líquido de todas as despesas, desconsiderando-se impostos; o administrador, por sua vez, é uma das próprias despesas da companhia e tenderá a zelar (i) pela saúde financeira da companhia para que ela possa continuar pagando sua remuneração, e (ii) por operações com baixo potencial de comprometer a companhia e levar acionistas a, no futuro, processá-lo. $^{123}$

Deve-se notar que nem todos os autores concordam com o modelo Jensen-Meckling de governança corporativa. Lynn Stout ataca este modelo sob três argumentos. Em primeiro lugar, contrariamente ao que fora pressuposto por Jensen e Meckling, os acionistas não são proprietários da companhia. Em segundo lugar, os acionistas não têm direito ao resultado residual. Em terceiro e último lugar, os acionistas não são principais e os administradores não são agentes contratados por eles. ${ }^{124}$

A despeito da sólida argumentação, este Autor acredita que o modelo Jensen-Meckling ainda se sustenta após todas as críticas.

\footnotetext{
122 "Given limited liability and diversification, rational shareholders should be indifferent to changes in corporate policies that merely alter exposure to unsystematic risks. Instead, they should focus on (and prefer) policies that portend a higher rate of return by increasing the firm's beta. In contrast, rational corporate managers - and, to a lesser extent, directors - should be risk-averse with respect to such policies. Corporate managers typically have substantial firmspecific human capital. Unfortunately for such managers, however, the risks inherent in firmspecific capital investments cannot be reduced by diversification; managers obviously cannot diversify their human capital among a number of different firms. As a result, managers will be adverse to risks shareholders are perfectly happy to tolerate." BAINBRIDGE, Stephen. The New Corporate Governance in Theory and Practice. p. 116.

${ }^{123}$ Id., ibid. p. 117. O autor aponta que este poderia ser um dos fundamentos da business judgment rule, regra do direito norte americano que presume a boa condução dos negócios pelo administrador da companhia e que, por consequência, tende a afastar revisão judicial de seus atos. ${ }^{124}$ STOUT, Lynn. Op. cit. p. 36.
} 
A primeira crítica de fato procede, posto que juridicamente os acionistas são proprietários das ações, mas não da companhia. Contudo, ela é inócua. Em nenhum momento o fato de o acionista ser chamado de "proprietário" da companhia traz qualquer mudança para o modelo. Ele seria o mesmo, ainda que o termo "proprietário" jamais fosse utilizado. De fato, a literatura já formulou esta crítica e o modelo continua inabalado. ${ }^{125}$

Além disso, por mais que os acionistas não sejam proprietários da companhia, isto não significa que sua vontade de maximização de lucros ${ }^{126}$ não deva ser atendida, pois os acionistas foram os proprietários do capital investido na companhia sob a forma de integralização das ações subscritas, e, sob certas condições, tanto jurídicas quanto de mercado, podem retirar o capital investido e aplicá-lo em outra companhia caso não estejam satisfeitos. Em outras palavras, no mercado de capitais as companhias competem por capital e a maneira mais óbvia de fazê-lo é maximizando a utilidade daqueles que nelas investem.

Em resposta à segunda crítica, deve-se de fato reconhecer que de fato não existe um direito absoluto ao resultado residual da companhia. A observação, contudo, também é inócua. A noção de um direito ao resultado residual é importante para o modelo Jensen-Meckling porque deixa claro que são os acionistas que estão mais expostos ao risco do empreendimento - e quanto a isto interessa muito pouco o direito dos acionistas em determinado regime jurídico, uma vez que o risco é uma realidade econômica e inafastável.

Jensen e Meckling construíram seu modelo em parte inspirados nas observações de Robert Wilson sobre como um grupo de agentes com

\footnotetext{
${ }^{125}$ A este respeito, cf. FAMA, Eugene. Op. cit. p. 290.

${ }^{126} \mathrm{Ou}$ vontade de qualquer outra coisa, afinal nem sempre querem os acionistas maximizar lucros.
} 
tolerâncias diferentes ao risco tomam decisões. ${ }^{127}$ Dizer que acionistas têm direito ao resultado residual significa dizer que eles, diferentemente dos administradores, somente podem receber o retorno de seu investimento se todos os fatores de produção forem pagos antes. Ou seja, dizer que eles têm um direito ao resultado residual pode ser impróprio (uma vez que não se trata de direito, e sim de mera expectativa), mas certamente não afasta a natureza daquilo a que a expressão se refere.

Por fim, em resposta à terceira crítica, deve-se ressaltar que a expressão "relação principal-agente" empregada por Jensen e Meckling em seu artigo tem um significado próprio definido no próprio artigo. A expressão é, portanto, puramente operativa, para fins de lógica formal. Ela é útil para uma análise do ponto de vista econômico e poderia ser completamente diferente sem nenhuma implicação para a análise. Pouco interessa, portanto, se segundo a tradição do common law os acionistas não se enquadram na categoria principal e os administradores não se enquadram na categoria agent.

\subsection{Conclusão parcial}

As companhias são instrumentos jurídicos concebidos para se realizar transações a um custo mais baixo, maximizando, portanto, os lucros daqueles que têm um interesse na lucratividade da atividade por ela exercida.

A governança corporativa, isto é, o modo pelo qual se estrutura e dirige a atividade da companhia, é relevante na medida em que pode fornecer incentivos ou desincentivos a aqueles que atuam em seu seio. Fazem parte dos mecanismo de governança corporativa a estrutura e o valor das remunerações percebidas pelos administradores das companhias.

${ }^{127}$ WILSON, Robert. Op. cit. 
Este trabalho é, portanto, um estudo - sobre o modo como a remuneração dos administradores de companhias abertas afeta o interesse dos acionistas, e de que modo a regulação do mercado de capitais pode licitamente atenuar os problemas criados pela remuneração (supondo-se que eles existam). 


\section{O Problema da Remuneração dos Administradores de Companhias Abertas}

Este breve capítulo será dividido em três partes. Na primeira, o Autor fará uma incursão na literatura norte americana para identificar quais tipos de problemas ela identificou como existentes ou potenciais decorrentes da remuneração dos administradores de companhias abertas.

Na segunda, o Autor analisará a escassa literatura brasileira sobre o tema para identificar as mesmas questões. A fim de complementar o estudos, tentará transpor, quando aplicável, os problemas norte americanos à realidade brasileira.

Por fim, o serão analisadas uma a uma as soluções propostas para os problemas identificados, levando em conta a sua adequação. O Autor adianta que a discussão deste Capítulo culminará em duas grandes questões: o sucesso (ou fracasso) dos mecanismos de remuneração variável e a necessidade e adequação (ou não) do mandatory disclosure enquanto solução (caso se entenda pelo fracasso).

\subsection{Nos EUA}

A literatura norte americana sobre o problema da remuneração dos administradores de companhias apresenta várias críticas às remunerações percebidas por eles, que dizem respeito tanto à sua estrutura quanto aos seus valores.

A Grande Depressão da década de 1930 foi o pano de fundo que definiu o debate norte americano sobre a remuneração dos diretores de companhias abertas. ${ }^{128}$ Harwell Wells aponta que em 1936, quando entrevistadas pela revista Fortune a respeito da remuneração de diretores,

${ }^{128}$ WELLS, Harwell. Op. cit. p. 705. 
certas pessoas teriam dito que nenhum homem vale cem mil dólares por ano. ${ }^{129}$ Paralelamente à ideia de que diretores poderiam estar recebendo somas altas de dinheiro para trabalhar pouco, havia também a ideia de que haveria um limite moral a quanto uma pessoa mereceria receber como remuneração. $^{130}$

Mais recentemente, nota-se o rancor público, alimentado pela mídia norte americana, contra o valor das remunerações recebidas por diretores. Charles Pak nota que "[o] o rancor público a respeito da remuneração de diretores tem se concentrado primariamente sobre a remuneração geral de diretores presidentes." ${ }^{\prime 31} \mathrm{Na}$ época, em 1992, a média da remuneração do diretor presidente das 800 maiores companhias norte americanas era 2.945.000 dólares. No mesmo levantamento, a maior média foi encontrada em 2007, no valor de 17.116 .000 dólares. ${ }^{132}$

A crise financeira de 2008 teria sido acompanhada de uma retórica do gênero. ${ }^{133}$ Além disto, ponderou-se, na época, que a crise poderia ter sido causada pela estrutura de remuneração dos diretores, que os incentivaria a contrair riscos para obter resultados de curto prazo. ${ }^{134}$

Como já mencionamos, por mais interessante que seja um estudo a respeito da desigualdade de remuneração entre executivos e trabalhadores,

\footnotetext{
${ }^{129}$ Id., ibid. p. 707.

${ }^{130}$ Id., ibid. p. 706.

131 PAK, Charles C. Toward Reasonable Executive Compensation: outcry for reform and regulatory response. 1994 Annual Survey of American Law, 1994. p. 634. Cf. também MARTIN, Susan Lorde. The Executive Compensation Problem. Dickinson Law Review, n. 98, 1993-1994. p. 239.

132 FORBES. Two Decades of CEO Pay. Disponível em $<$ http://www.forbes.com/lists/2012/12/ceo-compensation-12-historical-pay-chart.html>. Acesso em 11 nov. 2013.

133 Cf., por exemplo, CORKERY, Michael. Executive Pay and the Financial Crisis: a refresher course. The Wall Street Journal, 18 set. 2009. Disponível em $<$ http://blogs.wsj.com/deals/2009/09/18/executive-pay-and-the-financial-crisis-a-refreshercourse/>. Acesso em 11 nov. 2013.

${ }^{134}$ KELLER, Christopher; STOCKER, Michael. Executive Compensation's Role in the Financial Crisis. The National Law Journal, 18 nov. 2008. Disponível em <http://www.law.com/corporatecounsel/PubArticleCC.jsp?id=1202426091714\&slreturn=2013101 0210943> Acesso em 11. nov. 2013.
} 
este não é o escopo deste trabalho. Tampouco se inclui no escopo deste trabalho um exame de possíveis efeitos sistêmicos causados pela estrutura de incentivos dos administradores. ${ }^{135}$ A remuneração dos administradores de companhias será tratada por este estudo como um problema quando sua estrutura ou valor for a causa de problemas economicamente aferíveis aos acionistas em decorrência da relação principal agente.

No que tange ao objeto deste estudo, deve-se notar que ganhou proeminência na literatura norte americana a noção de um descolamento da remuneração dos administradores do desempenho dos mesmos. Os administradores estariam se beneficiando de sua remuneração sem atender aos interesses de seus principais. ${ }^{136}$

\subsubsection{A tese tradicional}

O descolamento do desempenho dos diretores da remuneração percebida pelos mesmos ocorre, segundo alguns, porque as companhias não negociam com diretores em condições equitativas, de mercado (at arm 'slength). ${ }^{137}$

\footnotetext{
${ }^{135}$ Bainbridge nota que, independentemente da influência da remuneração dos administradores sobre a crise, o problema estava localizado no setor financeiro. BAINBRIDGE, Stephen M. Corporate Governance after the Financial Crisis. p. 120. A respeito do tema na literatura brasileira, cf. NEGREIROS, Teresa. Remuneração e Risco no Setor Financeiro: novidades e tendências na Europa. Revista de Direito Bancário e do Mercado de Capitais, ano 14, n. 51, jan. mar. 2011. pp. 197-212.

${ }^{136}$ Deve-se notar que a literatura norte americana se concentra nos problemas da remuneração de diretores (executives). O Autor acredita que duas possíveis causas deste fenômeno sejam (i) a pressão popular e a retórica da mídia e dos políticos norte americanos contra a remuneração dos diretores e (ii) a regulação do Dodd-Frank Act de 2010, que recaiu sobre a remuneração dos diretores especificamente (seção 951 e seguintes). O Autor chamará a atenção do leitor para os casos em que a literatura estender aos membros de outros órgãos da administração (que não a diretoria) o raciocínio aplicável aos diretores. Cf. BEBCHUK, Lucian; FRIED, Jesse. Op. cit.; ELSON, Charles M. Director Compensation and the Management Captured-Board: the history of a symptom and a cure. SMU Law Review, vol. 50, 1996-1997. pp. 127-174; WELLS, Harwell. Op. cit. p. 694.

${ }^{137}$ Lucian Bebchuk e Jesse Fried tentam simplificar o que constituiria uma contratação entre a companhia e os diretores at arm's-length: "What would characterize an executive compensation arrangement produced by arm's-length bargaining between the executive and a board seeking to maximize shareholder value? To begin with, the contract must provide enough value to induce the executive to accept and remain in the position being offered. Thus, the contract must provide
} 
Stephen Bainbridge divide a remuneração dos diretores em três categorias: (i) pagamentos e benefícios não atrelados à performance da companhia, (ii) opções de compra de ações e outros mecanismos de incentivo baseados na performance das ações companhia, e (iii) bônus e outros mecanismos de incentivo atrelados à performance da companhia de acordo com determinados critérios contábeis. ${ }^{138}$

A respeito das categorias (i) e (iii), não há grandes divergências na literatura. Na realidade, desde a década de 1990 economistas e homens de negócios têm defendido a adoção de planos de opção de compra de ações em detrimento dos demais modelos de remuneração. ${ }^{139}$

A percepção, por diretores, de uma remuneração fixa, completamente desvinculada da performance da companhia, os incentiva a não assumir riscos, pois eles tenderão a priorizar a preservação dos ativos da companhia em detrimento da geração de renda; tenderão também a reter lucros dentro da companhia ao invés de distribuí-los aos acionistas. ${ }^{140}$

Por outro lado, atrelar a remuneração dos diretores à performance da companhia de acordo com determinados critérios contábeis também tem sido uma prática criticada pela literatura. A adoção destes modelos afeta a

benefits whose value meets or exceeds the value of the other opportunities available to the candidate. In addition, when rational, self-interested buyers and sellers transact, their contracts tend to avoid inefficient terms, that is, terms that reduce the size of the pie produced by the contractual arrangement and shared by the transacting parties." BEBCHUK, Lucian; FRIED, Jesse. Op. cit. p. 18.

${ }^{138}$ BAINBRIDGE, Stephen. Op. cit. p. 113.

${ }^{139}$ Id., ibid. p. 113. Charles Elson relata o seguinte: "On June 19, 1995, in what commentators termed a major development in American corporate governance, the National Association of Corporate Director' Commission on Director Compensation released a report calling for a radical overhaul of the compensation system for U.S. public company directors. Focusing on greater board equity ownership, the Commission, comprised of prominent senior executives, academics, shareholder activists, and compensation consultants, made a series of recommendations designed to improve corporate performance by changing board pay practices to more closely align "the interests of shareholders and directors."." ELSON, Charles M. Op. cit. p. 166. Ressalte-se que aqui a recomendação era dirigida a membros do conselho de administração, não a diretores.

${ }^{140}$ BAINBRIDGE, Stephen M. Op. cit. p. 113 
escolha de técnicas contábeis pelos diretores, com favorecimentos daquelas que trazem as receitas para o exercício presente. ${ }^{141}$

Por causa destes motivos, Stephen Bainbridge aponta que a literatura tem se concentrado nos modelos de remuneração abarcados pela categoria (ii) - planos de opção de compra de ações e outros mecanismos que vinculam a remuneração ao preço das ações no mercado. ${ }^{142}$

A ideia por trás da cessão de opções de compra de ações da companhia pode ser resumida no seguinte exemplo. Imagine-se que um determinado diretor recebe da companhia opções de compra de ações da própria companhia a $\mathrm{R} \$ 20,00$, exercíveis quatro anos após a sua investidura no cargo. Quando de sua investidura no cargo, a cotação das ações da companhia na bolsa era $\mathrm{R} \$ 10,00$. Isto significa que, para ter algum lucro ao exercer suas opções de compra, o diretor terá de trabalhar para fazer com que o valor das ações da companhia suba de $R \$ 10,00$ para $R \$ 20,00$ em quatro anos. ${ }^{143}$

\subsubsection{Pay without performance}

Em 2004, Lucian Bebchuk e Jesse Fried publicaram o livro Pay without Performance: the unfulfilled promise of executive compensation, no qual defendem, essencialmente, que (i) a negociação da remuneração dos

\footnotetext{
${ }^{141}$ Em 1985, Paul Healy conduziu um estudo empírico para testar estas premissas que ganhou grande relevância na literatura. Suas conclusões foram as seguintes: "There is a strong association between accruals and managers' income-reporting incentives under their bonus contracts. Managers are more likely to choose income-decreasing accruals when their bonus plan upper or lower bounds are binding, and income-increasing accruals when these bounds are not binding. Results of tests comparing accruals for firms whose bonus plans include and exclude an upper bound further support the theory: holdind cash flows constant, accruals are lower for companyyears with binding bonus plan upper bounds than for company-years with no upper bound. This difference in the timing or reported earnings is offset when bonus plan upper limits are not binding. [...] The results suggest that there is a high incidence of voluntary changes in accounting procedures during years following the adoption or modification of a bonus plan." HEALY, Paul. The Effect of Bonus Schemes on Accounting Decisions. Journal of Accounting and Economics, n. 7, 1985. p. 106 .

${ }^{142}$ BAINBRIDGE, Stephen M. Op. cit. p. 114.

${ }^{143} \mathrm{O}$ exemplo é uma adaptação do exemplo dado por Bainbridge. Id., ibid. p. 114.
} 
diretores não se dá em termos equitativos, e que (ii), porque a estrutura e o valor da remuneração se dão, em muitos casos, nos termos impostos pelos diretores, não são incentivos eficazes para alinhar seus interesses com os dos acionistas. $^{144}$

A publicação da obra, na realidade, representou o ápice de uma série de artigos dos próprios autores e de outros autores da Universidade de Harvard que questionam a ideia de que a remuneração dos administradores é mecanismo eficaz para alinhar os interesses dos administradores com os dos acionistas. ${ }^{145}$

A ideia fundamental de Bebchuk e Fried é que os diretores de companhias, especialmente das abertas, desfrutam, por vários motivos, de um poder da administração (managerial power), que os permite perceber valores mais altos do que aqueles que seriam recebidos caso os contratos se dessem em condições equitativas (at arm's length). ${ }^{146}$

Segundo os autores, a existência de managerial power nas companhias abertas norte americanas é justificada pelo fato de que o órgão incumbido de definir a remuneração dos diretores é o conselho de administração. Conselhos de administração de companhias abertas deixam

\footnotetext{
${ }^{144}$ Utilizando o vocabulário introduzido por Jensen e Meckling, a redução das perdas residuais se dá por meio de custos de monitoramento negociados em condições não equitativas.

${ }_{145}$ Cf. BEBCHUK, Lucian; FRIED, Jesse; WALKER, David. Managerial Power and Rent Extraction in the Design of Executive Compensation. The University of Chicago Law Review, vol. 69, 2002. Disponível em <http://papers.ssrn.com/abstract_id=316590>. Acesso em 11 nov. 2013; BEBCHUK, Lucian; FRIED, Jesse. Executive Compensation as an Agency Problem. Journal of Economic Perspectives, vol. 17, n. 3, 2003. pp. 71-92; e BEBCHUK, Lucian; FRIED, Jesse. Stealth Compensation via Retirement Benefits. Berkeley Business Law Journal, 2004. Disponível em 〈http://ssrn.com/abstract=583861〉. Acesso em 11 nov. 2013. Mais recentemente, foi publicado BEBCHUK, Lucian; COHEN, Alma; SPAMANN, Holger. The Wages of Failure: executive compensation at Bear Stearns and Lehman 2000-2008. European Corporate Governance Institute, Finance Working Paper $n$. 287/2010, jun. 2010. Disponível em <http://ssrn.com/abstract=1513522>. Acesso em 11 nov. 2013.

${ }^{146}$ Dizem os autores que o diretores extraem "rents" da companhia. Segundo eles, rents seriam "extra returns that firms or individuals obtain due to their positional advantages". BEBCHUK, Lucian; FRIED, Jesse. Pay without Performance: the unfulfilled promise of executive compensation. p. 61.
} 
para os comitês de remuneração (compensation committees) a tarefa de decidir os detalhes mais importantes da remuneração dos diretores. ${ }^{147}$

A importância dos comitês de remuneração não pode ser desconsiderada. Nos EUA, a maior parte dos conselheiros membros do comitê de remuneração das companhias abertas é independente. Uma pesquisa relatou que, em 2002, 73\% dos comitês de remuneração de empresas listadas na S\&P 1500 eram completamente independentes. Os regulamentos da NYSE, da NASDAQ ${ }^{148}$ e da AMEX determinam, à sua própria maneira, que a remuneração dos diretores seja votada por membros independentes do conselho de administração. ${ }^{149}$

Contudo, os autores argumentam que mesmo o fato de quem determina a remuneração dos diretores ser independente não significa que a contratação se dará em termos equitativos. Isso ocorre porque conselheiros de administração teriam incentivos pecuniários e não pecuniários para querer se reeleitos. Na realidade norte americana, na maioria esmagadora dos casos, a chapa proposta pela própria companhia seria a chapa vencedora. Em muitos casos, na realidade, é a única chapa. Para um membro do conselho de administração conseguir ser reeleito, portanto, a solução seria bastante simples - figurar na chapa proposta pela companhia. $^{150}$

Em muitos casos, o órgão da companhia encarregado de compor a chapa é o comitê de nomeação (nominating committee). Nos regulamentos das bolsas de valores, os requisitos de independência deste comitê se aproximaria muito dos requisitos do comitê de rmeuneração. Entretanto, a

\footnotetext{
${ }^{147}$ Id., ibid. p. 24.

148 O nome "NASDAQ" já foi a abreviação para National Association of Securities Dealers Automated Quotations. Contudo, com a desmutualização desta bolsa de valores, o nome deixou de ser uma abreviação. Por esse motivo, neste trabalho, não figura na Lista de Abreviações.

${ }^{149}$ Id., ibid. p. 24.

${ }^{150}$ Id., ibid. pp. 25-26.
} 
realidade dos dois comitês (de remuneração e de nomeação), seria diversa. Em primeiro lugar, os comitês de nomeação não apresentariam a independência dos de remuneração. Diretores presidentes normalmente têm uma vaga nesses comitês, e, segundo uma pesquisa realizada em 2002, apenas 50\% das companhias listadas no S\&P 1500 seriam completamente independentes. Em segundo lugar, mesmo quando diretores não fazem parte dos comitês de nomeação, eles - especialmente o diretor presidente - ainda assim teriam poder suficiente para barrar a entrada de candidatos na chapa. Dessa forma, membros do comitê de nomeação, do comitê de remuneração ou, mais largamente, do comitê de administração teriam um grande desincentivo para se opor à remuneração do diretor presidente ou de outros diretores. Quem se opuser às remunerações propostas pelo diretor presidente provavelmente não figuraria numa chapa e não seria reeleito. ${ }^{151}$

Outros incentivos fortes para os membros do conselho de administração concordarem em não se opor à remuneração de membros da diretoria seriam (i) relações de amizade e lealdade com membros da diretoria, (ii) o poder de autoridade exercido pelo diretor presidente, (iii) sentimentos de colegialidade e espírito de corpo, e (iv) a crença dos membros do conselho de administração, quando bem remunerados, de que tais práticas são salutares - chamados pelos autores de cognitive dissonance. ${ }^{152}$

Aí começaria a existência de um managerial power. De forma resumida, a realidade norte americana faria com que os membros do conselho de administração tivessem incentivos fortes para manter boas relações com os diretores. Uma das formas mais óbvias de fazê-lo seria não votar contrariamente a propostas de remuneração encaminhadas pelos

\footnotetext{
${ }^{151}$ Id., ibid. pp. 26-27.

${ }^{152}$ Id., ibid. pp. 31-34.
} 
próprios diretores ao conselho de administração. ${ }^{153}$ No cenário desenhado pelos autores, a estrutura de governança contida nos regulamentos das bolsas de valores mitigariam mas não eliminariam o poder do diretor presidente de afastar membros do conselho de administração que não cooperem com ele e de beneficiar os mais amigáveis.

Os autores, deve-se frisar, não acreditam que a remuneração baseada em desempenho esteja equivocada. Entendem, contudo, que ela não ganhou o apoio amplo que deveria ter ganho por parte de acionistas e membros do conselho de administração; ${ }^{154}$ e quando ganhou, foi utilizada como camuflagem por diretores para permitir a extração de benefícios da companhia. ${ }^{155}$

Ao final do livro, os autores propõem soluções para o problema, levando-se em conta o direito e o cenário de governança corporativa norte americanos.

Em primeiro lugar, entendem que os acionistas devem estar atentos para a remuneração dos diretores e apoiar estruturas baseadas em ações (equity-based) que tendam a eliminar possíveis valorizações não associadas à performance dos diretores, e sim em uma crescimento do mercado ou do setor da indústria em que a companhia atua. ${ }^{156}$

Entendem também que os acionistas devem apoiar uma maior conexão entre formas de remuneração e práticas relacionadas ao efetivo desempenho da companhia. Por exemplo, criticam a prática de pagamento de bônus aos diretores pela simples aquisição de uma companhia - o que

\footnotetext{
${ }^{153}$ BAINBRIDGE, Stephen. Op. cit. p. 115.

${ }^{154}$ BEBCHUK, Lucian; FRIED, Jesse. Op. cit. 190

${ }^{155}$ Id. ibid. pp. 67-70.

${ }^{156}$ Id., ibid. p. 190.
} 
não significa necessariamente um desempenho maior da companhia e para a qual nenhum incentivo seria necessário. ${ }^{157}$

Além disto, acionistas deveriam apoiar medidas que limitassem e restringissem a eliminação dos incentivos, pelos próprios diretores, conferidos pelas estruturas baseadas em ações. Diretores aos quais fossem outorgados planos de opções de compras não deveriam poder se desfazer de tais opções em um determinado período de tempo, mesmo que antes do atingimento deste período já fosse lucrativo o seu desfazimento. Restrições deveriam ser impostas à realização de operações de hedge pelos diretores, por meio das quais eles poderiam reduzir sua exposição ao preço das opções, reduzindo, portanto os incentivos. ${ }^{158}$

Acionistas deveriam também apoiar uma redução da prática de pagamentos gratuitos em caso de insucesso comercial. Golden parachutes, especialmente aqueles não acordados contratualmente, seriam ineficiências para os acionistas, pois representam gastos dissociados de qualquer incremento no desempenho da companhia. ${ }^{159}$

Por fim, os autores recomendam um escrutínio muito maior, por parte dos acionistas, de estruturas de remuneração fixa, especialmente aquelas camufladas sob outras rubricas. Seria o caso de planos de aposentadoria, contratos de prestação de serviços e empréstimos. ${ }^{160}$

É, contudo, outra recomendação feita por Bebchuk e Fried que motiva o atual debate acerca da divulgação da remuneração dos administradores de companhia aberta. Segundo eles, seria benéfico que

\footnotetext{
${ }^{157}$ Id., ibid. p. 190.

${ }^{158}$ Id., ibid. p. 191.

${ }^{159}$ Id., ibid. p. 191.

${ }^{160}$ Id., ibid. pp. 191-192. Esta prática não é nova. Relata Joel Seligman que o empréstimo, pela companhia, a seus próprios diretores, de grandes somas de dinheiro era prática comum no meio financeiro na década de 1920 nos EUA e foi trazida à tona pela Pecora Commission. Cf. SELIGMAN, Joel. Op. cit. pp. 25-26.
} 
fosse dada maior transparência às estruturas e valores das remunerações dos diretores. ${ }^{161}$

Aqui entraria o papel da regulação. Entendem os autores que seria necessária atuação regulatória no sentido de obrigar (i) a contabilização de todas as opções de compra de ações outorgadas a diretores, (ii) o cálculo da expressão monetária de todas as formas de remuneração dos diretores, (iii) a consideração de todas as formas de remuneração dos diretores, incluindo planos de aposentadoria e contratos de prestação de serviços, (iv) o cálculo dos ganhos obtidos pelos diretores com a venda de opções de compra de ações, e o confronto desse valor com a proporção do desempenho da companhia sobre o desempenho das demais companhias do setor, e (v) a compilação, pela companhia, de todas as vendas de opções de compra de ações pelo diretor a ele outorgadas pela companhia. ${ }^{162}$

Deve-se ressaltar, como já foi dito, que o disclosure das remunerações dos diretores já era objeto, à época, de regulação da SEC. ${ }^{163}$ As medidas propostas pelos autores serviriam para transformar o mero disclosure em transparency - isto é, efetiva difusão da informação.

Várias das recomendações formuladas pelos autores parecem ter prevalecido na política legislativa norte americana nos últimos anos. Contudo, como se analisará rapidamente a seguir, o Autor considera

\footnotetext{
${ }^{161}$ Os autores diferenciam o mandatory disclosure, já praticado pela SEC na época da redação do livro, de transparency. O primeiro carregaria uma noção muito mais técnico jurídica, enquanto o segundo carregaria a ideia de uma difusão maior da informação pela sociedade, para que todos os envolvidos possam fiscalizar as práticas da companhia. Ressaltam os autores que somente um aumento da transparência é capaz de elevar os custos associados à possibilidade de um ultraje (outrage costs), uma vez que ela significa que as informações reveladas de forma truncada a um órgão regulador e acessadas somente por analistas passam a ser traduzidas e ganham atenção midiática e das pessoas que realmente podem exercer pressão sobre os administradores e fazê-los sentir vergonha de suas práticas. Em suma, "[r]aw facts buried in a mountain of technical disclosure probably will not suffice." Id., ibid. 192-193.

${ }^{162}$ Id., ibid. pp. 193-194.

${ }^{163}$ Em 22.10.1992 entraram em vigor regras da SEC determinando como se daria o disclosure da remuneração dos diretores das companhias registradas. Tais regras serão examinadas abaixo. Cf. UNITED STATES. Federal Register, vol. 57, n. 204, 21 out. 1992. pp. 48126-48140; e MARTIN, Susan Lorde. Op. cit. pp. 247-250.
} 
improvável que todas as mudanças introduzidas no direito norte americano façam parte da agenda de Bebchuk e Fried.

\subsubsection{O estado atual: do Sarbanes-Oxley Act para o Dodd-Frank Act}

Muito antes do colapso da Enron e do Sarbanes-Oxley Act o disclosure da remuneração dos diretores já era obrigatório por força da regulação da SEC. Relatam Bebchuk e Fried que mesmo antes de 1992 o disclosure era obrigatório, mas as companhias emissoras tinham a liberdade de decidir como o fariam - algo que muitas vezes aproveitavam e camuflavam em longos textos com linguagem técnica e truncada, gerando difícil compreensão. ${ }^{164}$

Como comentado brevemente acima, a SEC, em 1992, instituiu um padrão para o disclosure da remuneração de diretores de companhias registradas. O disclosure deveria ser feito em formato de tabela cujo modelo seria fornecido pela própria SEC. Além da remuneração percebida pelo diretor presidente $(C E O)$, a tabela determina o disclosure da remuneração percebida pelos outros quatro diretores com a maior remuneração (letras A a D) dentro da companhia. A estrutura da remuneração deveria ser discriminada nos quesitos estabelecidos pela própria tabela (remuneração fixa, opções de compra de ações, etc.), e dentro de cada quesito deveria ser apontado o valor percebido por cada diretor. Ao final, a tabela demonstraria a remuneração total percebida por cada diretor, bem como a remuneração total paga pela companhia dentro de cada quesito. $^{165}$

Nos últimos anos, contudo, a tendência regulatória cresceu. Com efeito, várias das recomendações formuladas por Bebchuk e Fried se

\footnotetext{
${ }^{164}$ BEBCHUK, Lucian; FRIED, Jesse. Op. cit. pp. 67-68.

${ }^{165}$ Cf. UNITED STATES. Federal Register, vol. 57, n. 204, 21 out. 1992. p. 48130.
} 
tornaram, para o arrepio de alguns autores, como Stephen Bainbridge ${ }^{166} \mathrm{e}$ Roberta Romano, ${ }^{167}$ lei ou ato normativo da SEC.

Mesmo antes da publicação da obra de Bebchuk e Fried, o SarbanesOxley Act, promulgado em 30.07.2002 logo após o colapso da Enron, procurou dar tratamento a algumas questões relevantes ao tema deste trabalho.

O principal dispositivo do Sarbanes-Oxley Act em relação à remuneração de administradores das companhias abertas é a seção 402, que, ao emendar o Securities Exchange Act, vedou o empréstimo de qualquer quantia a membros do conselho de administração e executive officers por companhia emissora de valores mobiliários. ${ }^{168}$

Os significados das expressões "personal loan" e "to extend, maintain or arrange for the extension of credit" do dispositivo se estenderiam, em tese, até a adiantamentos para despesas com viagens, pagamento de despesas processuais pela companhia quando o diretor ou executive officer é processo por assuntos relacionados à companhia, o uso

\footnotetext{
${ }^{166}$ BAINBRIDGE, Stephen. Dodd-Frank: quack corporate governance round II. Minnesota Law Review, n. 95, 2010-2011. pp. 1779-1821.

167 ROMANO, Roberta. The Sarbanes-Oxley Act and the Making of Quack Corporate Governance. Yale Law Journal, n. 114, 2004-2005. pp. 1521-1611; ROMANO, Roberta. Does the Sarbanes-Oxley Act Have a Future? Yale Journal on Regulation, n. 26, 2009. pp. 229-341.

${ }^{168}$ É a seguinte a nova redação da seção 13(k)(1) do Securities Exchange Act: "It shall be unlawful for any issuer (as defined in section 2 of the Sarbanes Oxley-Act of 2002), directly or indirectly, including through any subsidiary, to extend or maintain credit, to arrange for the extension of credit, or to renew an extension of credit, in the form of a personal loan to or for any director or executive officer (or equivalent thereof) of that issuer. An extension of credit maintained by the issuer on the date of enactment of this subsection shall not be subject to the provisions of this subsection, provided that there is no material modification to any term of any such extension of credit or any renewal of any such extension of credit on or after that date of enactment." John McGuiness entende que executive officer seria "[...] the president; any vice president in charge of a principal business unit, division, or function (such as sales, administration, or finance); and any other officer or other person who performs a policy-making function, including for a subsidiary." MCGUINESS, John F. Impact of Sarbanes-Oxley Act on Benefits and Executive Compensation. Journal of Deferred Compensation, n. 8, vol. 2. p. 56.
} 
de cartão de crédito para despesas pessoais, empréstimos e adiantamentos de realocação, entre outros. ${ }^{169}$

Além deste dispositivo, o Sarbanes-Oxley Act, na seção 304, determinou que, caso a companhia emissora seja requerida a submeter uma nova demonstração financeira devido a um material noncompliance da própria companhia emissora, como resultado de uma misconduct, o diretor presidente e o diretor financeiro responsável deverão reembolsar a companhia no valor de qualquer bônus ou remuneração baseada em incentivos (incentive-based) ou em ações (equity-based) recebida nos últimos doze meses, bem como de qualquer lucro que obtiveram com a venda de valores mobiliários de emissão da companhia. ${ }^{170}$ Esta norma é mais conhecida como clawback provision. ${ }^{171}$

Por fim, a seção 306 do Sarbanes-Oxley Act veda a compra, venda ou transferência de valores mobiliários por membros do conselho de administração e executive officers nos períodos de vedação à negociação (blackout periods) nos casos em que o referido valor mobiliário foi adquirido pelo membro do conselho de administração ou executive officer em decorrência de sua atividade enquanto tal. ${ }^{172}$

\footnotetext{
${ }^{169}$ Id., ibid. p. 57. Para Bainbridge, a lista de isenções é sensivelmente maior e não engloba, por exemplo, cartões de crédito corporativos. BAINBRIDGE, Stephen M. Op. cit. p. 125.

170 "SEC. 304 FORFEITURE OF CERTAIN BONUSES AND PROFITS

(a) ADDITIONAL COMPENSATION PRIOR TO NONCOMPLIANCE WITH COMMISSION FINANCIAL REPORTING REQUIREMENTS. - If an issuer is required to prepare an accounting restatement due to the material noncompliance of the issuer, as a result of misconduct, with any financial reporting requirement under the securities laws, the chief executive officer and chief financial officer of the issuer shall reimburse the issuer for - (1) any bonus or other incentive-based or equity-based compensation received by that person from the issuer during the 12-month period following the first public issuance or filing document embodying such financial report requirement; and (2) any profits realized from the sale of securities of the issuer during that 12-month period.

(b) COMMISSION EXEMPTION AUTHORITY. - The Commission may exempt any person from the application of subsection (a), as it deems necessary and appropriate."

${ }_{171}$ BAINBRIDGE, Stephen M. Op. cit. p. 129

172 “SEC. 306. INSIDER TRADES DURING PENSION FUND BLACKOUT PERIODS

(a) Prohibition of Insider Trading During Pension Fund Blackout Periods. - (1) Except to the extent otherwise provided by rule of the Commission pursuant to paragraph (2), it shall be unlawful for any director or executive officer of an issuer of any equity security (other than an
} 
Em 05.01.2010, pouco mais de um ano após a eclosão da crise financeira de 2008, foi promulgado o Dodd-Frank Act, que, na área que toca ao direito societário, se propôs a aumentar o nível de disclosure das companhias abertas e, portanto, melhorar o padrão de governança nos EUA.

Atualmente, as seções 951 e seguintes do Dodd-Frank Act, promulgado em 2010, estabelecem um controle rígido sobre a remuneração dos administradores, sua estrutura e a forma pela qual elas são votadas.

De longe a seção mais polêmica do Dodd-Frank Act é a 951, que estipula o chamado "say on pay". Segundo esta seção, as companhias devem promover uma votação dos acionistas em caráter consultivo, em periodicidade não inferior a três anos, sobre a remuneração dos executivos cujo disclosure é obrigatório por força do item 402 da S-K Regulation. ${ }^{173}$ São eles: o diretor presidente, o diretor financeiro e os outros três administradores com maior remuneração. ${ }^{174}$ De acordo com a mesma seção 951, a regra do polêmico say on pay também se aplica aos golden parachutes de executive officers. ${ }^{175}$ Ressalta-se, contudo, que a nova seção

exempted security), directly or indirectly, to purchase, sell, or otherwise acquire or transfer any equity security of the issuer (other than an exempted security) during any blackout period with respect to such equity security if such director or officer acquires such equity security in connection with his or her service or employment as a director or executive officer."

${ }^{173} \mathrm{O}$ item 402 da S-K Regulation determina a prestação de certas informações periódicas e pode ser comparado ao Formulário de Referência da ICVM 480. Sua reforma mais profunda foi a de 1992, que incluiu o dever de divulgação da remuneração do diretor presidente e dos outros quatro diretores com maior remuneração da companhia.

${ }^{174}$ A nova seção 14A(a)(1) do Securities Exchange Act tem a seguinte redação: “( a) IN GENERAL. Not less frequently than once every 3 years, a proxy or consent authorization for an annual or other meeting of the shareholders for which the proxy solicitation rules of the Commission require compensation disclosure shall include a separate resolution subject to shareholder vote to approve the compensation of executives, as disclosed pursuant to section 229.402 of title 17, Code of Federal Regulations, or any successor thereto."

175 A nova seção 14A(b)(1) do Securities Exchange Act tem a seguinte redação: “(1) DISCLOSURE. - In any proxy or consent solicitation material (the solicitation of which is subject to the rules of the Commission pursuant to subsection (a)) for a meeting of the shareholders occurring after the end of the 6-month period beginning on the date of enactment of this section, at which shareholders are asked to approve an acquisition, merger, consolidation, or proposed sale or other disposition of all or substantially all the assets of an issuer, the person making such solicitation shall disclose in the proxy or consent solicitation material, in a clear and simple form in accordance with regulations to be promulgated by the Commission, any agreements or understandings that such person has with any named executive officers of such issuer (or of the 
14A(c) do Securities Exchange Act deixa claro que o voto dos acionistas, nestes dois casos, não vincula a companhia emissora, tampouco o conselho de administração.

A seção 952 procurou, por meio de um controle sobre entidades autorreguladoras, aumentar a independência dos comitês de remuneração. A seção 952 requer que a SEC tome ações diretivas no sentido de obrigar as entidades autorreguladoras a adotar padrões de listagem demandando que todos os membros do comitê de compensação sejam independentes. ${ }^{176}$ Segundo Bainbridge, há controvérsia a respeito do comando do dispositivo: não se sabe ao certo se ele determina que todas as companhias listadas pelas entidades autorreguladoras tenham comitês de remuneração integralmente independentes. ${ }^{177}$

De todo modo, em 30.03.2011, a SEC propôs a Rule 10C-1, que determina às bolsas de valores norte americanas que proíbam a listagem de companhias que não seguirem as determinações da própria Rule 10C-1 a respeito do comitê de remuneração e de certos aspectos da contratação de consultores de remuneração.

A Rule 10C-1 determina, dentre outras coisas, que todos os membros dos comitês de remuneração devem ser membros independentes do conselho de administração das companhias listadas nas bolsas. Para

acquiring issuer, if such issuer is not the acquiring issuer) concerning any type of compensation (whether present, deferred, or contingent) that is based on or otherwise relates to the acquisition, merger, consolidation, sale, or other disposition of all or substantially all of the assets of the issuer and the aggregate total of all such compensation that may (and the conditions upon which it may) be paid or become payable to or on behalf of such executive officer."

176 A nova seção $10 \mathrm{C}(\mathrm{a})(1)$ do Securities Exchange Act tem a seguinte redação: "(1) LISTING STANDARDS. - The Commission shall, by rule, direct the national securities exchanges and national securities associations to prohibit the listing of any equity security of an issuer, other than an issuer that is a controlled company, limited partnership, company in bankruptcy proceedings, open-ended management investment company that is registered under the Investment Company Act of 1940, or a foreign private issuer that provides annual disclosures to shareholders of the reasons that the foreign private issuer does not have an independent compensation committee, that does not comply with the requirements of this subsection." Este é o mais importante de uma série de dispositivos que visa a intensificar a independência dos comitês de remuneração.

${ }^{177}$ BAINBRIDGE, Stephen. Op. cit. p. 129. 
determinar se o membro do conselho de administração é independente ou não, a norma determina que as bolsa levem em consideração dois critérios: (i) se a remuneração do membro do conselho de administração é oriunda de alguma forma da companhia, e (ii) se o diretor possui algum vínculo com a companhia, suas subsidiárias ou afiliadas de suas subsidiárias.

Além disto, a Rule 10C-1 determina que as listagens das bolsas de valores obriguem que comitês de remuneração tenham a autoridade para contratar a consultoria de um consultor de remuneração, sendo responsável direto pela nomeação, remuneração e supervisão de seu trabalho. ${ }^{178}$

A seção 953 determina que a SEC emane ato normativo obrigando as companhias a divulgar a relação entre a remuneração dos diretores e o desempenho financeiro da companhia de forma clara. ${ }^{179}$ Além disto, determina o disclosure (i) da remuneração média de todos os empregados da companhia exceto o diretor presidente, (ii) da remuneração do diretor presidente, e (iii) a proporção entre as duas. ${ }^{180}$ Conhecido como pay ratio, este disclosure é bastante polêmico e que está sendo recentemente regulamentado pela SEC. O Autor fará algumas breves considerações sobre ele posteriormente.

\footnotetext{
${ }^{178} \mathrm{O}$ Autor tem conhecimento de que pelo menos a NASDAQ tenha submetido à SEC mudanças em seu regulamento para adequação à Rule 10C-1. Cf. SEC Release No. 34-68640.

${ }^{179}$ A nova seção 14(i) do Securities Exchange Act tem a seguinte redação: “(i) DISCLOSURE OF PAY VERSUS PERFORMANCE. - The Commission shall, by rule, require each issuer to disclose in any proxy or consent solicitation material for an annual meeting of the shareholders of the issuer a clear description of any compensation required to be disclosed by the issuer under section 229.402 of title 17, Code of Federal Regulations (or any successor thereto), including information that shows the relationship between executive compensation actually paid and the financial performance of the issuer, taking into account any change in the value of the shares of stock and dividends of the issuer and any distributions. The disclosure under this subsection may include a graphic representation of the information required to the disclosed."

${ }^{180}$ É a seguinte a redação da seção 953(b)(1): “(1) IN GENERAL. - The Commission shall amend section 229.402 of title 17, Code of Federal Regulations, to require each issuer to disclose in any filing of the issuer described in section 229.10(a) of title 17, Code of Federal Regulations (or any successor thereto) - (A) the median of the annual total compensation of all employees of the issuer, except the chief executive officer (or any equivalent position) of the issuer; $(B)$ the annual total compensation of the chief executive officer (or any equivalent position) of the issuer; and $(C)$ the ratio of the amount described in subparagraph $(B) . "$
} 
A seção 954, semelhante à seção 304 do Sarbanes-Oxley Act, determina que as bolsas de valores somente admitam a listagem de companhias que tenham implementado claw-back provisions. Há algumas pequenas diferenças entre os dois dispositivos, contudo, que não interessam à nossa análise. ${ }^{181}$ Cabe notar, no momento, que a análise da linguagem nos permite concluir que o escopo de aplicação da seção 954 do Dodd-Frank Act é substancialmente mais amplo que o da seção 304 do Sarbanes-Oxley Act. $^{182}$

Por fim, o art. 955 requer que as companhias divulguem, em seus proxy statements, se permitem ou não que empregados e membros do conselho de administração contratem instrumentos financeiros que reduzam a exposição dessas pessoas ao risco de desvalorização das ações da companhia. ${ }^{183}$

\subsubsection{A reação contrária}

Tanto o Sarbanes-Oxley Act quanto o Dodd-Frank Act são objeto de crítica por parte de doutrinadores norte americanos.

\footnotetext{
${ }^{181}$ A nova seção 14D(b) do Securities Exchange Act tem a seguinte redação: “(b) RECOVERY OF FUNDS.-The rules of the Commission under subsection (a) shall require each issuer to develop and implement a policy providing - (1) for disclosure of the policy of the issuer on incentive-based compensation that is based on financial information required to be reported under the securities laws; and (2) that, in the event that the issuer is required to prepare an accounting restatement due to the material noncompliance of the issuer with any financial reporting requirement under the securities laws, the issuer will recover from any current or former executive officer of the issuer who received incentive-based compensation (including stock options awarded as compensation) during the 3-year period preceding the date on which the issuer is required to prepare an accounting restatement, based on the erroneous data, in excess of what would have been paid to the executive officer under the accounting restatement."

${ }^{182}$ BAINBRIDGE, Stephen M. Op. cit. p. 132.

${ }^{183}$ A nova seção 14(j) do Securities Exchange Act tem a seguinte redação: “(j) DISCLOSURE OF HEDGING BY EMPLOYEES AND DIRECTORS. - The Commission shall, by rule, require each issuer to disclose in any proxy or consent solicitation material for an annual meeting of the shareholders of the issuer whether any employee or member of the board of directors of the issuer, or any designee of such employee or member, is permitted to purchase financial instruments (including prepaid variable forward contracts, equity swaps, collars, and exchange funds) that are designed to hedge or offset any decrease in the market value of equity securities - (1) granted to the employee or member of the board of directors by the issuer as part of the compensation of the employee or member of the board of directors; or (2) held, directly or indirectly, by the employee or member of the board of directors."
} 
No que tange ao say on pay, Stephen Bainbridge é uma das vozes mais contrárias: "Say on pay é mais um exemplo de governança corporativa charlatã."184

Ele reporta que a noção de say on pay foi amplamente defendida por think tanks de governança corporativa e investidores institucionais como um meio de evitar a assunção excessiva de risco por parte de diretores (excessive risk-taking). Contudo, conferir tal poder aos acionistas - que têm, pela sua posição dentro da estrutura da companhia, uma preferência pelo risco - somente faz com que os interesses dos administradores se alinhem mais com os dos acionistas - em direção a uma maior assunção de risco. $^{185}$

Mesmo o fato de que a manifestação dos acionistas sobre a remuneração prevista na seção 14(a)(1) do Securities Exchange Act tenha caráter meramente consultivo não significa que os acionistas não terão influência sobre a remuneração a ser efetivamente contratada com os diretores. $^{186}$

Jeffrey Gordon aponta que o say on pay levaria a soluções de remuneração do tipo one size fits all. Isto ocorreria porque investidores institucionais entregariam a avaliação das práticas de remuneração de aproximadamente dez mil companhias norte americanas às mãos de empresas especializadas. Como avaliação detalhada e personalizada é cara e a aplicação de "diretrizes" ou "melhores práticas "é mais barato, as soluções de remuneração se restringiriam a poucos modelos. A solução

\footnotetext{
184 Tradução livre. No original: "Say on pay is yet another example of quack corporate governance." BAINBRIDGE, Stephen. Op. cit. p. 136.

${ }^{185}$ Id., ibid. p. 136.

${ }^{186} \mathrm{O}$ autor é favorável à doutrina do director primacy, segundo à qual o conselho de administração é o órgão ao qual se atribui a tomada de decisões. Deixar muitas decisões serem tomadas pelos acionistas e permitir que os acionistas persigam judicialmente a responsabilização dos administradores de forma mais frequente são medidas que aumentam, em última análise, os custos para os próprios acionistas. Id., ibid. p. 134.
} 
legislativa deveria permitir ao acionista escolher a adoção do say on pay na sua companhia. ${ }^{187}$

No que tange ao pay ratio disclosure previsto na seção 953 do DoddFrank Act, a própria SEC, ao propor regulamentação da matéria, comentou que

"[p]articularmente, a ausência de uma falha de mercado específica identificada como a motivação para a promulgação deste dispositivo traz desafios significativos à quantificação de potenciais benefícios econômicos, se é que estes existem, que advêm do pay ratio disclosure."188

No mesmo documento, a SEC registra que há vários comentários à proposta de regulamentação que questionam a importância do pay ratio para uma decisão de investimento. Bainbridge entende que o ônus para se cumprir com a divulgação desta informação será enorme. ${ }^{189}$ Mesma opinião foi notada pela SEC ao analisar os comentários recebidos. ${ }^{190}$

A clawback provision contida no Dodd-Frank Act pode ser sobreinclusiva e subinclusiva ao mesmo tempo. Explica-se: é sobreinclusiva porque abrange todos os "executive officers", sem discriminar quais são culpados e quais são inocentes; é subinclusiva porque restringe o significado de "executive officers" ao presidente, qualquer vice presidente encarregado de uma principal business unit, divisão, ou função; e qualquer outro diretor ou pessoa que exerça uma policy-making function, inclusive para uma subsidiária. ${ }^{191}$ Sobretudo, segundo Bainbridge, as clawback

\footnotetext{
${ }^{187}$ GORDON, Jeffrey N. "Say on Pay": cautionary notes on the U.K. experience and the case for shareholder opt-in. Harvard Journal on Legislation, n. 46, 2009. pp. 325-326.

${ }^{188}$ SEC Releases Nos. 33-9452; 34-70443, p. 91.

${ }^{189}$ BAINBRIDGE, Stephen M. Op. cit. p. 127.

${ }^{190}$ SEC Releases Nos. 33-9452; 34-70443, p. 96.

${ }^{191}$ Id., ibid. pp. 131-132. A definição de "executive officer" é a apresentada em MCGUINESS, John F. Op. cit. p. 56.
} 
provisions sabotam a política federal de promover uma remuneração baseada em desempenho. ${ }^{192}$

Bainbridge nota também que não há explicação empírica para um reforço obrigatório da independência dos comitês de remuneração. Segundo ele, novamente se adotou um modelo one size fits all, que, contudo não tem conexão com a realidade. Estudos empíricos teriam demonstrado que não há correlação entre independência dos membros do comitê de remuneração e desempenho da companhia. ${ }^{193}$ Mesmo no modelo de managerial power proposto por Bebchuk e Fried, a independência do comitê de remuneração é tratada como insuficiente para evitar o benefício dos diretores. ${ }^{194}$

Por fim, a proibição de empréstimos a administradores em geral, além de trazer consigo problemas de interpretação já demonstrados, seria de uma necessidade discutível. Por mais que empréstimos possam ser uma forma de camuflar remuneração a administradores, não seria nem um pouco evidente que uma proibição fosse melhor que o mandatory disclosure de determinadas situações. ${ }^{195}$

Todas as circunstâncias levadas em conta, uma análise superficial e global das últimas mudanças no direito norte americano relacionadas à remuneração de administradores nos leva á conclusão de que, sem muitos estudos empíricos que o suportem, o governo federal impôs ao mercado um pesado ônus regulatório - tanto em vedações quanto em práticas de disclosure. Tampouco há estudos que demonstrem de forma clara as consequências das normas promulgadas. ${ }^{196}$

\footnotetext{
192 BAINBRIDGE, Stephen M. Op. cit. p. 132.

${ }^{193}$ Id., ibid. p. 129.

${ }^{194}$ BEBCHUK, Lucian. FRIED, Jesse. Op. cit. pp. 25-27.

195 Id., ibid. p. 126.

196 Bainbridge é especialmente enfática em relação à imprevisibilidade das consequências das clawback provisions. BAINBRIDGE, Stephen M. Op. cit. p. 132.
} 
Bainbridge argumenta que tanto o Sarbanes-Oxley Act quanto o Dodd-Frank Act foram fruto de uma agenda que nada tem a ver com resolver as causas das crises financeiras de 2000 e 2008. Segundo ele, os que provavelmente mais usarão os dispositivos do Dodd-Frank Act serão aqueles que pressionaram por sua adoção. ${ }^{197}$

\subsection{No Brasil}

A primeira consideração a ser feita a respeito do problema da remuneração dos administradores de companhias abertas brasileiras é que a relação principal agente não se dá aqui de forma tão nítida quanto nos EUA ou no RU.

Em 1987, Eizirik notou que o controle gerencial no Brasil ainda era um mito, pois não haveria um nível de dispersão acionária tão acentuado quanto aquele observado por Berle e Means em 1932 nos EUA. ${ }^{198}$

The Modern Corporation and Private Property apontava que 65\% das duzentas maiores companhias norte americanas eram controladas pelos diretores ou por instrumentos legais que reduziam a participação acionária. Na década de 1970, Robert Larner concluiu que $80 \%$ das duzentas maiores empresas norte americanas tinham controle gerencial. ${ }^{199}$

\footnotetext{
197 “"...] Dodd-Frank's corporate governance provisions were included in the legislation because key policy entrepreneurs were able to hijack the legislative process to advance a long-standing political agenda. Specifically, as we have seen, all the major governance provisions were strongly supported by activists in the institutional investor communicty, especially union and state and local pension funds, for whom such items as proxy access and say-on-pay were high priority agenda items. It seems reasonable to assume that these same activist investores will be the shareholders most likely to make use of their new powers." BAINBRIDGE, Stephen M. "DoddFrank": quack corporate governance round II. p. 1.816.

${ }^{198}$ EIZIRIK, Nelson. O Mito do "Controle Gerencial": alguns dados empíricos. Revista de Direito Mercantil, Financeiro, Industrial e Econômico, ano XXVI, n. 66, abr. - jun. 1987. pp. 105-106.

${ }^{199}$ LARNER, Robert. Management Control and the Large Corporation, apud EIZIRIK, Nelson. Op. cit. p. 103. O critério usado tanto no estudo de Berle e Means quanto de Larner pare se caracterizar o controle gerencial era a inexistência de acionistas, ou grupo de acionistas, com mais de $10 \%$ do capital votante. EIZIRIK, Nelson. Op. cit. p. 103.
} 
No caso brasileiro, seria absolutamente incorreto cogitar-se de controle gerencial. Com base em dados colhidos em 31.12.1985, a Superintendência de Projetos e Estudos Econômicos da CVM divulgou estudo no qual se observa, dentre 456 companhias, representativas de cerca de $90 \%$ do patrimônio líquido total das companhias abertas brasileiras, que em nenhuma o principal acionista possui participação abaixo de $10 \%$ do capital votante. A conclusão é que inexistiria no Brasil, à época, controle gerencial. $\mathrm{O}$ estudo também demonstrou que, na média das companhias abertas, o acionista majoritário detinha quase $70 \%$ das ações com direito de voto. Em 18,64\% das companhias o acionistas controlador possuía de 90\% a $100 \%$ do capital votante. ${ }^{200}$

Desde 1985 até tempos mais recentes o capital das companhias abertas se tornou mais disperso pelo mercado. Em estudo feito por Valadares e Leal, das 325 companhias abertas listadas na BOVESPA que submeteram o Informativo Anual à CVM em 1997 (com informações referentes, portanto, a 1996), 203 tinham acionista com participação no capital votante superior a 50\% - o equivalente a 62,5\%. Nestas 203 companhias, o acionista controlador detinha uma média de $74 \%$ do capital votante - a mediana era $73,5 \% .^{201}$ Como na Europa continental, o Brasil teria, à época, uma maioria de companhias com controle majoritário. ${ }^{202}$

Tal concentração, segundo os autores, teria sido facilitada em parte pela possibilidade, à época, de emissão de ações com restrição ao direito de voto em até dois terços do capital da companhia. A composição média do capital das companhias foi apontado pelo estudo como sendo 54\% de ações com direito a voto e $46 \%$ de ações sem direito a voto. Este mecanismo teria

\footnotetext{
${ }^{200}$ Id., ibid. p. 105.

201 VALADARES, Sílvia Mourthé; LEAL, Ricardo Pereira Câmara. Ownership and Control Structure of Brazilian Companies. Disponível em <http://ssrn.com/abstract=213409>. Acesso em 11 nov. 2013. p. 8.

${ }^{202}$ Id., ibid. p. 9.
} 
sido utilizado por acionistas controladores para reter controle da companhia sem ter que deter mais de $50 \%$ de seu capital. ${ }^{203}$

Em estudo mais recente, Érica Gorga analisou 530 companhias abertas listadas na BOVESPA em 19.12.2007. Após filtrar as amostras, a amostragem chegou a 339 companhias abertas, divididas em: 92 listadas no Novo Mercado, 20 listadas no Nível 2, 40 listadas no Nível 1 e 183 no mercado padrão. ${ }^{204}$ No Novo Mercado, Gorga notou uma predominância de companhias sem controle majoritário (27 companhias de 92). Contudo, nos demais níveis o controle majoritário foi a regra: no Nível 2, 15 companhias de 20; no Nível 1, 31 companhias de 44; no mercado padrão, 133 companhias de $183 .^{205}$ A conclusão é que a concentração de propriedade do capital aumenta conforme se sai do Novo Mercado em direção a segmentos de governança corporativa menos rígidos, que não possuem a one-shareone-vote rule. ${ }^{206}$

Contudo, Gorga conduz, no mesmo artigo, um segundo estudo, este levando em consideração quem são os últimos acionistas das companhias (ultimate shareholders). Eles podem ser (i) indivíduos ou famílias, (ii) investidores estrangeiros, (iii) o governo, ou (iv) investidores institucionais. $^{207}$

\footnotetext{
${ }^{203}$ Id., ibid. pp. 9-10.

${ }^{204}$ GORGA, Érica. Changing the Paradigm of Stock Ownership from Concentrated towards Dispersed Ownership? Evidence from Brazil and consequences for emerging markets. Disponível em 〈http://ssrn.com/abstract=1121037〉. Acesso em 11 nov. 2013. p. 27. Cabe notar que Novo Mercado, Nível 1, Nível 2 e mercado padrão eram, à época, os quatro diferentes níveis de governança corporativa aos quais as companhias poderiam aderir ao serem listada na BOVESPA. Os requisitos para a listagem constam dos regulamentos de cada segmento. Deve-se notar que atualmente a BM\&FBOVESPA possui também o segmento BOVESPA Mais. Cf. BM\&FBOVESPA. $O$ que São Segmentos de Listagem. Disponível em $<\mathrm{http} / / / \mathrm{www}$.bmfbovespa.com.br/pt-br/servicos/solucoes-para-empresas/segmentos-de-listagem/oque-sao-segmentos-de-listagem.aspx?idioma=pt-br>. Acesso em 11 nov. 2013.

${ }^{205}$ GORGA, Érica. Op. cit. pp. 86-87. tabelas 8-11.

${ }^{206}$ Id., ibid. p. 28.

${ }^{207}$ Id., ibid. p. 33.
} 
Os dados sugerem uma dispersão ainda menor de capital que aquela sugerida pelo primeiro estudo de seu artigo: no Novo Mercado, 47 companhias de 92 possuíam acionista controlador; no Nível 2, 18 companhias de 20; no Nível 1, 40 companhias de $43 .{ }^{208}$

Antes esses dados, não é à toa que Christine Mallin nota que no Brasil a maior parte das companhias abertas se encontra nas mãos de um grupo controlador, geralmente representando o interesse de famílias. ${ }^{209}$

O choque de interesses entre acionistas e administradores propugnado pela agency theory não ocorre no Brasil com a intensidade que ocorre nos EUA e no RU. Érica Gorga, após concluir que "[...] a figura do controle gerencial é mais ficção do que realidade [...]" nota que o problema de agência, no Brasil, se dá, na realidade, entre os acionistas minoritários e os majoritários. ${ }^{210}$

No que toca às ações integrantes do bloco de controle, o acionista controlador seria simultaneamente o principal e seu próprio agente; contudo, no caso das ações não integrantes do bloco de controle, o acionista controlador não é o principal, mas somente o agente. Em outras palavras, o controlador é o agente do acionista minoritário. ${ }^{211}$

Neste cenário complexo do mercado de capitais brasileiro, em que se introduz a relação principal-agente do controlador com os minoritários no já existente modelo de relação principal-agente entre acionista e administrador, a teoria deve ganhar novos contornos:

"O mundo real, entretanto, pode apresentar situações de agência mais complexas, abrangendo maior número de partes envolvidas. Este parece ser o

\footnotetext{
${ }^{208}$ Id., ibid. pp. 90-92. tabelas 12-14. A informação sobre o mercado padrão não parece estar disponível.

${ }^{209}$ MALLIN, Christine. Op. cit. p. 352.

${ }^{210}$ GORGA, Érica. Direito Societário Atual. p. 55

${ }^{211}$ Id., ibid. pp. 55-56.
} 
caso do problema de agência de um grupo de sociedades anônimas brasileiras, em face da evolução recente das estruturas de propriedade, nas quais existem nas quais existem poucos acionistas com bloco de ações suficientemente grande para eleger alguns administradores, mas sem poder suficiente para controlar a gestão de modo incontestável. Nesta nova situação, o conflito de agência se caracterizaria numa relação tripolar entre acionistas e detentores de blocos de ações relevantes vs. administradores vs. acionistas minoritários e, assumindo que cada parte tende a perseguir seus próprios interesses, particularmente quando o monitoramento se torna mais difícil e custoso, tal problema de agência tripolar pode, assim, resultar na possibilidade de aumento significativo dos custos de agência, de modo a dificultar a harmonização dos diferentes interesses $e$ prejudicar a gestão." 212

Em suma, em mercados como o brasileiro, a consequência seria um aumento acentuado dos custos de agência que pode inviabilizar a atividade da companhia. A solução seria um confinamento da possibilidade de extração de benefícios privados do controle do negócio social.

No caso da remuneração dos administradores das companhias abertas, cabe um exame de qual a melhor forma de seu confinamento. Mais especificamente, e tendo em vista o escopo deste trabalho, cabe um exame da efetividade do mandatory disclosure para confinar tal extração de benefícios privados. Tendo isso em visto, o Autor, a seguir, analisará a recente regulação do mercado de capitais brasileiro a respeito da matéria. Ao final deste Capítulo, o comparará com as soluções americanas e concluirá.

\subsubsection{O estado atual}

Embora a LSA tutele de forma bastante minuciosa o acesso a informações da companhia pelo acionista, ${ }^{213}$ a atividade regulatória,

\footnotetext{
${ }^{212}$ Id., ibid. p. 98.

${ }^{213}$ Podem ser identificados, na LSA, os seguintes mecanismos legais que permitem o acesso à informação pelo acionista: (i) pedido de informações ao administrador de companhia aberta (art. 157 , § $1^{\circ}$, da LSA); (ii) divulgação de fato relevante (art. 157, § $4^{\circ}$, da LSA); (iii) demonstrações financeiras da companhia (art. 122, III, da LSA); (iv) esclarecimentos prestados em assembleia (art. 134, § $1^{\circ}$, da LSA); e (v) o próprio conselho fiscal da companhia (art. 161 e seguintes da LSA). Por sua vez, a Lei n. 6.385/76 prevê a prestação de informações periódicas pela companhia aberta no art. $22, \S 1^{\circ}$, I, embora não entre em seus detalhes. Segundo o dispositivo, cabe à CVM regulamentar a matéria. Mesmo tratamento é dado à já mencionada divulgação de fato relevante no art. $22, \S 1^{\circ}$, VI, da Lei n. 6.385/76.
} 
voltada ao mercado de capitais, tem um campo de incidência muito mais reduzido que nos EUA.

Pode-se destacar três atos normativos da CVM nos últimos anos a respeito que procuram regular a remuneração de administradores ${ }^{214}$ de companhias abertas: (i) a Deliberação n. 560, (ii) a ICVM 480, e (ii) a ICVM 481. A segunda, como já notado, está sendo discutida judicialmente pelo IBEF.

A Deliberação n. 560 da CVM, de 11.12.2008, aprovou o Pronunciamento Técnico CPC 05. Este determinou que as demonstrações financeiras das companhias abertas refletissem de forma detalhada e fidedigna as transações com partes relacionadas, dentre as quais administradores. Seu item 16 tem a seguinte redação:

"16. A entidade deve divulgar a remuneração do pessoal-chave da administração no total e para cada uma das seguintes categorias:

(a) benefícios de curto prazo a empregados e administradores;

(b) benefícios pós-emprego;

(c) outros benefícios de longo prazo;

(d) benefícios de rescisão de contrato de trabalho; $e$

(e) remuneração baseada em ações."

$\mathrm{O}$ "pessoal-chave da administração", por sua vez, é definido no item 5 como

"as pessoas que têm autoridade e responsabilidade pelo planejamento, direção e controle das atividades da entidade, direta ou indiretamente, incluindo qualquer administrador (executivo ou outro) dessa entidade."

A Deliberação n. 560 não exige a divulgação individualizada dos valores da remuneração do "pessoal-chave da administração", tampouco de sua estrutura. Na realidade, ela exige somente que as transações e saldos

\footnotetext{
${ }^{214}$ Deve-se perceber, desde o início, que no Brasil as atenções regulatórias não são quase exclusivamente voltadas à figura do diretor - como ocorre nos EUA. Pelo contrário, membros do conselho de administração e mesmo membros do conselho fiscal são abarcados pelas regras emanadas pela CVM.
} 
existentes sejam divulgados nas demonstrações financeiras da companhia (item 3).

A respeito do conceito de demonstrações financeiras, nada melhor que o comentário de José Luiz Bulhões Pedreira:

\begin{abstract}
"Demonstrações financeiras são quadros que apresentam, de modo resumido e com disposição padronizada, informações quantificadas sobre as finanças da companhia.

[...]

Uma dessas informações (o balanço patrimonial) informa a situação do patrimônio, ou posição financeira da companhia, em determinada data. Outras informam o resultado do funcionamento da companhia durante um período (demonstração do resultado do exercício) ou espécies de mutações patrimoniais ocorridas durante o mesmo período (demonstrações dos lucros ou prejuízos acumulados, das mutações do patrimônio líquido e das origens e aplicações de recursos). $" 215$
\end{abstract}

Nas demonstrações financeiras,

"[o] conhecimento do patrimônio das sociedades empresárias requer outras informações que somente podem ser obtidas mediante escrituração de todas as mutações patrimoniais, classificadas e agregadas em contas segundo plano que permita conhecer os diversos aspectos das suas finanças." 216

Ou seja, as demonstrações financeiras devem observar determinada técnica contábil. Os valores das remunerações, portanto, são agrupados, quando de mesma natureza, e divulgados sob a forma escritural.

Como relata José Luiz Bulhões Pedreira, “[o] direito comercial criou originalmente a obrigação do comerciante de manter escrituração coom o fim de garantir os direitos daqueles que com ele negociavam." 217 O que o nível de disclosure da Deliberação n. 560 permite é o conhecimento do tamanho e da composição do ativo e do passivo da companhia de uma forma mais fidedigna - nada mais.

\footnotetext{
${ }^{215}$ PEDREIRA, José Luiz Bulhões. Exercício Social e Demonstrações Financeiras. In: LAMY FILHO, Alfredo. PEDREIRA, José Luiz Bulhões (coord.). Op. cit. pp. 1.501-1.502.

${ }^{216}$ Id., ibid. p. 1.502

${ }^{217}$ Id., ibid. p. 1.530.
} 
Orientação diferente seguiu a ICVM 480, ora objeto de discussão judicial. O item 13 do Formulário de Referência (Anexo 24) determina o disclosure, de forma pormenorizada, de várias informações relativas à remuneração dos administradores. As informações a serem divulgadas variam de acordo com a categoria de emissor que se trata - companhias registradas sob a categoria $\mathrm{A}$, descritas no art. $2^{\circ}, \S 1^{\circ}$, da ICVM 480, como emissoras de ações ou quaisquer títulos conversíveis ou que dêem direito a ações, têm a obrigação de divulgar mais informações que as companhias registradas sob a categoria B. A categoria B é basicamente residual e procura abarcar emissores de títulos com liquidação financeira (debt capital), em oposição à categoria A, que procura abarcar ações ou títulos de liquidação física em ações (equity capital) - são os equity-based instruments.

Sem entrar em detalhes a respeito da controvérsia gerada pelo item 13.11 do Formulário de Referência, é necessário ressaltar que não é desprezível o número de informações a serem divulgadas a respeito das remunerações de membros da diretoria e dos conselhos de administração e fiscal. Não cabe aqui um exame detalhado de todas as informações (posto que o Formulário de Referência tende a ser auto explanativo). Entretanto, algumas delas são: (i) objetivos da política de remuneração, (ii) composição da remuneração, (iii) valores mínimos e máximos previstos nos planos de remuneração baseados em bônus e em ações, (iv) número de ações e cotas detidas, no Brasil ou no exterior, do emissor ou de seus controladores diretos ou indiretos, (v) informações relativas às opções em aberto, planos de previdência e golden parachutes, (vi) modelos de precificação das ações e opções, e (vii) remuneração paga aos membros desses órgao que não em decorrência da função que exercem.

Por fim, a ICVM 481, que disciplina os pedidos públicos de procuração, editada em 17.12.2009, determinou, no seu art. 12, que a 
companhia deve fornecer aos acionistas, no mínimo, a proposta de remuneração dos administradores e as informações indicadas no item 13 do Formulário de Referência sempre que a assembleia geral for convocada para deliberar sobre a remuneração dos administradores.

Deve-se destacar que a redação do art. $1^{\circ}$, parágrafo único, sugere que ela se aplica exclusivamente a emissores registrados sob a categoria $\mathrm{A}$ da ICVM 480, pois refere-se a "companhias abertas que possuam ações admitidas a negociação em mercados regulamentados". A ICVM 481, portanto, não se aplica a eventual assembleia de debenturistas - o argumento é reforçado pelo fato de o caput do dispositivo especificar que se aplica às assembleias "gerais" e "especiais", mas não se pronunciar sobre as assembleias de debenturistas. ${ }^{218}$

Outro detalhe a ser observado é que a Instrução, por mais que diga disciplinar os pedidos públicos de procuração, se aplica claramente aos anúncios de convocação (art. $1^{\circ}$, I, da ICVM 481). Ou seja, no sentir deste Autor a ICVM 481 complementa a ICVM 480 na medida me que determina a prestação da mesma gama de informações (item 13 do Formulário de Referência) também quando do anúncio de convocação de assembleia geral.

Além disso, a ICVM 481 determinou, no art. 13, que a convocação de assembleia geral para aprovação de plano de remuneração com base em ações deverá ser acompanhada de determinadas informações constantes de seu Anexo 13. Novamente, não cabe aqui enumerar todas as informações requeridas por este documento - grosso modo, exige que se divulgue as principais características do plano de remuneração, sua justificativa e uma estimativa das despesas decorrentes. Evidentemente, também exige que uma cópia dele seja fornecida.

\footnotetext{
${ }^{218} \mathrm{O}$ Autor desconhece, na prática norte americana ou mesmo brasileira, a existência de pedido público de procurações de debenturistas. O Autor tampouco pretende fazer aqui considerações valorativas a este respeito.
} 


\subsection{Conclusão parcial}

Uma comparação da regulação brasileira com a norte americana torna nítido, em primeiro lugar, o fato de que no Brasil esta se restringiu a promover o disclosure de informações julgadas relevantes para o mercado. Stephen Bainbridge observa que a tradição norte americana de regulação do mercado de capitais sempre foi marcada por uma junção de normas antifraud com normas de disclosure. A política nunca foi a de entrar no comportamento substantivo dos emissores dos títulos. Tanto o SarbanesOxley Act quanto o Dodd-Frank Act mudaram esse cenário com normas de disclosure que, contudo, pretendem alterar o comportamento dos emissores e forçar a adoção de determinados modelos de governança às companhias abertas norte americanas. ${ }^{219}$

Outra observação que vale ser reiterada é a disparidade entre os mercados de capital brasileiro e norte americano. Nitidamente o direito norte americano se desenvolveu lá como uma reação aso problemas típicos de uma grande dispersão acionária. No Brasil, a realidade é bastante diferente.

Coutinho de Abreu, a respeito desta diferença, comenta que

"[...] algumas medidas de governação societária faladas além-Atlântico são adoptadas ou adoptáveis por cá. Por exemplo, o reforço dos deveres de lealdade e responsabilidade dos administradores, o fortalecimento do papel fiscalizador dos administradores não executivos independentes (nas sociedades de estrutura monística ou quase-monística), a transparência das contas sociais. Importa não sobrestimar certas diferenças, ressaltadas aliás em designações-contraposições usuais como market-oriented vs. control-oriented systems." 220

A observação do autor português pode ser mais ou menos procedente, dependendo da visão que o leitor tenha sobre o papel da regulação do mercado de capitais. Entretanto, não é essa a crítica que este

\footnotetext{
${ }^{219}$ BAINBRIDGE, Stephen M. Op. cit. p. 1.801.

${ }^{220}$ ABREU, Jorge Manuel Coutinho de. Op. cit. p. 17.
} 
Autor faz à regulação brasileira. O Autor entende que o disclosure pode ser uma medida destinada a regular também a relação entre acionistas majoritários e minoritários.

Deve-se notar, e aqui tem início a crítica, que a uniformidade de soluções que adveio com o Sarbanes Oxley Act e o Dodd-Frank Act é um fenômeno que não passa despercebido por Bainbridge:

\begin{abstract}
"Em contraste, a uniformidade imposto pela lei federal preclui experimentos com diferentes modelos de regulação. Deste modo, conforme cresce a esfera de regulação federal, o espaço para ideias regulatórias novas e melhores serem desenvolvidas encolhe. Ao invés dos laboratórios do federalismo, corremos o risco de ficarmos presos com regras que podem muito bem estar erradas desde o princípio e, porque Washington somente se move em resposta a crises, podem rapidamente ficar obsoletas. ${ }^{, 221}$
\end{abstract}

A crítica do autor se dirige a uma intervenção federal demasiada no direito do mercado de capitais em detrimento da atuação a nível estadual, algo aplicável unicamente à realidade federalista norte americana. Contudo, este Autor entende que o raciocínio pode ser estendido a qualquer formulação regulatória do tipo one size fits all.

Da mesma forma que um Estado norte americano pode servir de laboratório para experimentos em matéria de direito societário e do mercado de capitais, as companhias podem, na visão do Autor, por meio de ação individual, inovar e promover o disclosure da informação que eventualmente considerarem relevante. Da mesma forma, acionistas especialmente investidores institucionais, que têm adquirido cada vez mais importância no mercado de capitais - podem pressionar as companhias investidas para a realização do disclosure que entenderem relevante para

\footnotetext{
221 "In contrast, the uniformity imposed by federal law precludes experimentation with differing modes of regulation. Accordingly, as the sphere of federal domination grows, the room for new and better regulatory ideas to be developed shrinks. Instead of the laboratories of federalism, we risk being stuck with rules that may well be wrong from the outset and, because Washington moves only in response to crises, may quickly become obsolete". BAINBRIDGE, Stephen M. Op. cit. p. 1.795.
} 
suas decisões de investimento e suas políticas de votação. Em contraste a uma atuação "a portas fechadas", dentro da companhia, também é perfeitamente possível imaginar uma atuação dos órgãos autorreguladores no sentido da promoção do disclosure.

Para este Autor, o melhor caminho a se trilhar no mercado de capitais é aquele que deixa os próprios agentes entrarem em concerto e escolherem suas próprias soluções, levando em conta os custos e os benefícios de levar a cabo as obrigações e direitos que contraem.

O mandatory disclosure, em especial aquele encontrado na ICVM 480 e da ICVM 481, impede que os agentes do mercado negociem e cheguem a acordos quanto ao nível de disclosure que atende suas necessidades.

Como visto, o Dodd-Frank Act traz consigo um custo alto de complicance por parte das companhias. No Brasil, embora não haja estudo sobre o tema, este Autor entende que o fornecimento de todas as informações constantes do item 13 do Formulário de Referência também trará um custo elevadíssimo. Basta lembrar de determinados dispositivos, alguns de cumprimento extremamente difícil, ${ }^{222}$ outros que requerem informações pouco objetivas. ${ }^{223}$ A submissão dessas informações pressupõe que elas sejam antes organizadas e compiladas. Isso, por óbvio, acarreta custos, e, por outro lado, nem sempre traz benefícios à companhia ou ao mercado.

\footnotetext{
${ }^{222}$ A declaração da "quantidade de ações ou cotas direta ou indiretamente detidas, no Brasil ou no exterior, e outros valores mobiliários conversíveis em ações ou cotas, emitidos pelo emissor, seus controladores diretos ou indiretos, sociedades controladas ou sob controle comum", por parte de administradores e membros do conselho fiscal (item 13.5).

${ }^{223}$ Uma explicação sobre "como a política de remuneração se alinha aos interesses do emissor de curto, médio e longo prazos" (item 13.1(e)).
} 
Mesmo a tese proposta por Bebchuk e Fried, que explica e justifica parte considerável desta orientação regulatória, tanto nos EUA quanto no Brasil, é bastante discutível. Core, Guay e Thomas, por exemplo, entendem que a independência absoluta do conselho de administração pode não ser desejável, uma vez que este órgão também pratica outros atos que nao negociar a remuneração de diretores e que podem ser melhor desempenhados por um conselho não independente. Mais que isso, prevêem que

"[...] quando um novo diretor president é contratado, espera-se que contratos ótimos sejam estruturados ex ante para levar com consideração que o diretor presidente irá construir managerial power ex post e com o tempo., ${ }^{224}$

Bainbridge aponta outros estudos que concluem que os CEOs enriqueceram porque os acionistas enriqueceram. Segundo um deles, o aumento de seis vezes no valor da remuneração dos CEOs entre 1980 e 2003 teria sido acompanhado por um aumento de também seis vezes na capitalização das maiores companhias abertas norte americanas. ${ }^{225}$ Segundo ele, isto demonstraria que, pelo menos nos EUA, a necessidade de regulação não ficou comprovada. ${ }^{226}$

No Brasil a ausência de estudos sobre o tema somente reforça a necessidade de cautela com a matéria. O Autor concede que a divulgação de dados a respeito da remuneração de administradores de companhias é um tema delicado no Brasil, e que um "pontapé” regulatório talvez encoraje os agentes do mercado a pensar em soluções para aumentar o monitoramento de administradores a baixos custos. Contudo, quando encarados com a obrigatoriedade de cumprir com a exaustividade regulatória da ICVM 480 e

\footnotetext{
${ }^{224}$ CORE, John E.;GUAY, Wayne R.; THOMAS, Randall S. Is U.S. CEO Compensation Inefficient Pay without Performance? Michigan Law Review, 103, 2004-2005. p. 1.164.

${ }^{225}$ GABAIX, Xavier; LANDIER, Augustin. Why Has CEO Pay Increased So Much? apud BAINBRIDGE, Stephen M. Op. cit. p. 1.810 .

${ }^{226}$ BAINBRIDGE, Stephen M. Op. cit. p. 1.811.
} 
da ICVM 481, os agentes, na visão deste Autor, não terão incentivos para implementar soluções privadas. 


\section{Juridicidade da Regulação da Matéria}

Desde sua criação, a CVM tem cumprido seu papel de proteger o investidor por meio da edição de normas que obrigam o full disclosure - ou algo próximo dele - a respeito dos papéis negociados no mercado de capitais. Em outras palavras, a regulação do mercado de capitais brasileiro, a exemplo do norte americano, assumiu a orientação de obrigar a divulgação ao mercado de informações consideradas relevantes para a negociação dos papéis por investidores. ${ }^{227}$

O Brasil adotou recentemente duas relevantes soluções para o problema da remuneração dos administradores de companhias abertas, consubstanciadas na ICVM 480 e na Deliberação n. 560.

O presente Capítulo procura investigar se estão dentro da competência normativa da CVM a edição destes dois atos administrativos normativos. Teria a CVM a competência para editar ato criando a obrigação, para a companhia, de divulgar as remunerações máxima, mínima e média dos membros de cada um de seus órgãos da administração, bem como participações detidas pelos mesmos em outras sociedades? Teria a CVM a competência para editar ato criando a obrigação, para a companhia, de divulgar da estrutura da remuneração de administradores?

O Autor, para responder a essas perguntas, traçará (i) uma breve introdução à regulação do mercado de capitais, seguida de (ii) uma análise do direito positivo brasileiro que define e delimita a competência normativa da CVM e (iii) uma reflexão acerca da constitucionalidade formal dos atos administrativos normativos editados pela CVM. Ao examinar estas questões, o Autor também fará um breve exame da ação movida pelo IBEF

\footnotetext{
${ }^{227}$ DUBEUX, Julio Ramalho. A Comissão de Valores Mobiliários e os Principais Instrumentos Regulatórios do Mercado de Capitais Brasileiro. Porto Alegre: Sergio Antonio Fabris, 2006. p. 43.
} 
em face da CVM em que se pretende a declaração de ilegalidade de parte da ICVM 480, analisando um a um os argumentos apresentados por ambas as partes. $^{228}$

\subsection{A regulação do mercado de capitais e a Lei $n .6 .385 / 76$}

Em 1976, a promulgação e entrada em vigor da Lei n. 6.385/76 operou uma reforma do SFN, dividindo a regulação do mercado financeiro em duas entidades de direito público pertencentes à administração pública federal indireta: o BACEN e a CVM.

O mercado financeiro é composto pelos mercados (i) de crédito, (ii) de capitais, (iii) monetário, e (iv) cambial. ${ }^{229} \mathrm{Na}$ sistemática anterior à Lei n. 6.385/1976, a competência normativa e fiscalizadora sobre o mercado financeiro brasileiro - cujo quadro legal era (e ainda é) denominado Sistema Financeiro Nacional - recaia unicamente sobre o Banco Central do Brasil $^{230}$. A Lei n. 6.385/76 transferiu à CVM as competências normativa e fiscalizadora relacionadas ao mercado de capitais. ${ }^{231}$

A ideia de uma autoridade reguladora do mercado de valores mobiliários não era nova em 1976, tendo ganhado força na década de 1920 nos Estados Unidos. Nos EUA tal noção estava amparada na teoria da

\footnotetext{
${ }^{228} \mathrm{O}$ Autor nota que a ação judicial referida encontra-se em curso perante a $5^{\mathrm{a}}$ Vara Federal da Seção Judiciária do Rio de Janeiro. Quando da elaboração deste trabalho, a ação encontrava-se em sede de apelação, tendo o IBEF obtido sentença favorável no primeiro grau.

${ }^{229}$ COMISSÃO NACIONAL DAS BOLSAS DE VALORES. Introdução ao Mercado de Ações. Rio de Janeiro: CNBV, 1984. pp. 31-33.

${ }^{230}$ A centralização da supervisão do Sistema Financeiro Nacional foi criticada por Rubens Requião como ineficiente, pois sobrecarregava o Banco Central com a supervisão de todo o mercado financeiro. $\mathrm{O}$ autor também critica que, diferentemente do anteprojeto, o projeto de lei apresentado ao Congresso Nacional compromete a independência da CVM na supervisão do mercado de valores mobiliários. Segundo ele, a intenção das modificações feitas ao anteprojeto teriam sido intencionais para não retirar do Banco Central a competência sobre o mercado de valores mobiliários. REQUIÃO, Rubens. Considerações sobre o Projeto de Criação da Comissão de Valores Mobiliários (CVM). Revista de Direito Mercantil, Industrial, Econômico e Financeiro, ano XIV, n. 20, 1975. pp. 102-103.

${ }^{231}$ EIZIRIK, Nelson. Reforma das S.A. e do Mercado de Capitais. Rio de Janeiro: Renovar, 1997. p. 137.
} 
discricionariedade técnica ${ }^{232}$ e na experiência com a Interstate Commerce Commission desde $1887 .^{233}$

Naquele país, apesar de algumas crises em que se questionou a imparcialidade e a independência das agências reguladoras, o modelo regulatório se implantou de forma ampla e profunda desde então. $\mathrm{Na}$ Inglaterra o processo de regulação foi implantado mais fortemente a partir de 1984 , com o modelo de privatização. ${ }^{234}$ Outros países, em período histórico similar, também experimentaram o fenômeno das agências reguladoras, como Espanha e Argentina. ${ }^{235}$

A CVM foi inspirada na Securities and Exchange Commission, entidade análoga norte americana criada em 1934 pelo Securities Exchange Act. $^{236}$ A descrição desta entidade e de sua atuação no mercado de securities norte americano, bem como do contexto de sua criação, são úteis para se entender em que medida a experiência norte americana influenciou a brasileira e permite contrastar os limites impostos ao poder normativo das duas entidades pelos respectivos ordenamentos, seja com o propósito de aproximação ou de distanciamento.

$\mathrm{Na}$ realidade, a criação de uma entidade reguladora e fiscalizadora do mercado de securities norte americano já era debatida em 1914. Na época, o Congresso dos Estados Unidos, no âmbito do Committee on Interstate and Foreign Commerce, se preocupou com a regulação de securities emitidas por common carriers - basicamente, a figura do

\footnotetext{
232 PIETRO, Maria Sylvia Zanella di. Discricionariedade Técnica e Discricionariedade Administrativa. Revista Eletrônica de Direito Administrativo Econômico, n. 9, fev. - abr. 2007. Salvador, Instituto Brasileiro de Direito Público. Disponível em <http://www.direitodoestado.com/revista/REDAE-9-FEVEREIRO-2007MARIA\%20SYLVIA.pdf>. Acesso em 11 nov. 2013. p. 8.

${ }^{233}$ TÁCITO, Caio. Agências Reguladoras da Administração. Revista de Direito Administrativo, vol. 221 , jul. - set. 2000. p. 4.

${ }^{234}$ Id., ibid. p. 4.

${ }^{235}$ Id., ibid. p. 5.

${ }^{236}$ DUBEUX, Julio Ramalho. Op. cit. p. 38.
} 
common law para o que conhecemos como transportadoras. Muito embora uma autoridade federal com poderes regulatórios sobre a emissão de securities não tenha sido criada, a ideia foi discutida ${ }^{237}$ e constou de relatório encaminhado ao presidente dos Estados Unidos. ${ }^{238}$ Como pode ser observado nas transcrições, contudo, o debate se concentrava na emissão de securities por common carriers, não de forma genérica por public corporations.

Durante o período das blue sky laws, a regulação de emissão de securities nos Estados Unidos era regulada única e exclusivamente pela legislação estadual e pelas comissões estaduais, cuja principal tarefa era não

\footnotetext{
237 “MR. F. C. STEVENS. (...) Now, its is a disadvantage to do that - having five States to approve that issue, none of which have anything to do with the expenditure of that money. But if a central authority like the Interstate Commerce Commission could supersede all of those States and assume jurisdiction which would be conclusive, would it not be a benefit to the road and to the public and to the value of its securities?

MR. STRAUSS. In my judgment it would. The reason I have not laid great stress upon it is because I imagined that politically speaking - I mean not using it in a narrow sense but in a wide sense this country was not yet ready to take from all of its 48 States that power which they now enjoy, and to vest it exclusively in the Federal Government. However, if it could be done, in my personal judgment it would be very advantageous. (...) If that were done, then the act permitting incorporation under a Federal charter could embody in it many details of sound financing recommended by the securities commission, such as shares of no par value, sale of stock at a discount with amortization of that discount within a period of years, etc.
}

(...)

MR. STRAUSS. My answer to that is this: I said Interstate Commerce Commission. I think it ought to be a separate commission or perhaps a separate division of that commission. I am assuming a Government commission that would devote its time exclusively to the issue of securities. That would certainly be a great deal better and would rob my criticism of some of its value." HOUSE OF REPRESENTATIVES OF THE UNITED STATES OF AMERICA. Sixty-Third Congress. Committee on Interstate and Foreign Commerce. Regulation of the Issuance of Stocks and Bonds by Common Carriers. Hearings before the Committee on Interstate and Foreign Commerce. Statement of Mr. Frederick Strauss, New York City. Washington: Government Printing Office, 1914. pp. 23-24. (destaque do Autor.)

238 "A Federal requirement conflicting with a State requeriment might leave us in an even worse case; for the impossibility of obeying both authorities would be made an excuse for obeying neither, This would clearly be true until the paramount authority of the Federal Government was established.

7. ENFORCED UNIFORMITY NOT YET AVAILABLE

To make legislation of this kind effective, it would be necessary to provide Federal agencies for carrying out its requirements in detail. We should be compelled either to burden the Insterstate Commerce Commission with a large amount of additional work, or to create a new commission to supervise railroad incorporation and construction in different parts of the country." HOUSE OF REPRESENTATIVES OF THE UNITED STATES OF AMERICA. Sixty-Third Congress. Committee on Interstate and Foreign Commerce. Regulation of the Issuance of Stocks and Bonds by Common Carriers. Hearings before the Committee on Interstate and Foreign Commerce. Report of the Railroad Securities Commission. Washington: Government Printing Office, 1914. p. 40. 
a de garantir o maior nível de disclosure possível de informações relacionadas às securities, mas de evitar fraudes nas suas emissões. ${ }^{239} \mathrm{Em}$ 1911 foi promulgada a primeira blue sky law, no Kansas. No mesmo diploma legal foi criada a autoridade reguladora do mercado de securities mais antiga dos Estados Unidos. ${ }^{240}$

\subsection{Valores mobiliários, competência da CVM e a ICVM 480}

A análise da competência normativa da CVM tem início na noção de valor mobiliário. Com efeito, a Lei n. 6.385/76 dispõe, em seus arts. $2^{\circ}$, $\S 3^{\circ}$, e, sobretudo, $8^{\circ}$, inciso I, ampla competência da CVM para regulamentar os dispositivos da mesma e da LSA.

De forma precisa, Eizirik et alli resumem a competência da CVM. Esta estaria

"[...] circunscrita e limitada aos emissores de valores mobiliários, seus controladores e administradores, assim como às entidades integrantes do sistema de distribuição de valores mobiliários, auditores independentes e demais pessoas que atuam profissionalmente neste mercado." ${ }^{241}$

Como a própria lei e a doutrina indicam, a definição de valor mobiliário é essencial para que se entenda o escopo da Lei n. 6.385/76 e, por conseguinte, da competência normativa da CVM. É isto que este Autor exporá a seguir, abordando (i) a inspiração francesa original da Lei n. 6.385/76, e, em seguida (ii) a aproximação do modelo norte americano.

\subsubsection{Valeurs mobilières: a inspiração francesa}

\footnotetext{
${ }^{239}$ HAZEN, Thomas Lee. The Law of Securities Regulation, apud DUBEUX, Julio Ramalho. Op. cit. p. 39. n. de rodapé 57.

240 KANSAS OFFICE OF THE SECURITIES COMMISSIONER. History. Disponível em < http://www.ksc.ks.gov/index.aspx?nid=154>. Acesso em 11 nov. 2013.

${ }^{241}$ EIZIRIK, Nelson; GAAL, Ariádna B.; PARENTE, Flávia; HENRIQUES, Marcus de Freitas. Mercado de Capitais: regime jurídico. $3^{\mathrm{a}}$ ed. revista e ampliada Rio de Janeiro: Renovar, 2011. p. 28.
} 
$\mathrm{O}$ anteprojeto da Lei n. 6.385/76 apresentado ao então Ministro da Fazenda Mario Henrique Simonsen pela comissão de juristas encabeçada por Alfredo Lamy Filho e José Luiz Bulhões Pedreira adotou, em seu art. $2^{\circ}$, o conceito francês de valores mobiliários. Segundo Ripert,

\begin{abstract}
"[a] expressão valores mobiliários designa os títulos negociáveis representantes dos direitos dos sócios ou dos mutuários a longo prazo. Se emprega igualmente a expressão títulos de Bolsa; ela é mais estrita que a anterior, pois nem todos os valores mobiliários são negociáveis na Bolsa. Tanto uma quanto a outra afirmam $o$ caráter móvel do título."242
\end{abstract}

$\mathrm{Na}$ mesma obra, Ripert prossegue, caracterizando os valores mobiliários como bens móveis a fungíveis. Contudo, a fungibilidade dos valores mobiliários não é a mesma do Direito Civil, que se refere à falta de individualização da coisa. Com efeito, os valores mobiliários podem ser individualizados de acordo com o nome do portador e o número de ordem. A fungibilidade é de ordem econômica, uma vez que um título tem exatamente o mesmo valor que outro. É até possível o atingimento de uma fungibilidade jurídica entre valores mobiliários - quando eles são depositados na CCDVT o portador deixa de conhecer a numeração de seu título. $^{243}$

Em seu Traité des valeurs mobilières et des effets publics, Buchère entende que a noção de valor mobiliário compreende

"[...] as inscrições de empréstimos do Estado, as ações do Banco da França, aquelas emitidas pelas sociedades financeiras ou industriais francesas ou estrangeiras, as obrigações municipais ou departamentais, os títulos de

\footnotetext{
${ }^{242}$ Tradução livre. No original: "L'expression valeurs mobilières désigne des titres négociables représentant des droits d'associés ou de prêteurs à long terme. On emploie également l'expression titres de Bourse; elle est plus étroite que la précédente, car toutes les valeurs mobilières ne sont pas negociables à la Bourse. L'une et láutre affirment le caractère mobile du titre." Em RIPERT, Georges. Traité Élémentaire de Droit Commercial. Paris: LGDJ, 1947. p. 572.

${ }^{243}$ Id., ibid. p. 574. Evidentemente, a "fungibilidade jurídica" do título pode se operar de forma similar no direito brasileiro; por exemplo, mediante o depósito dos títulos em instituição escrituradora, conforme previsto nos arts. 34 e 35 da Lei n. 6.404/76. José Baptista Neto, em interpretação similar, aponta que a fungibilidade do título se limita aos direitos cartulares, uma vez que os títulos em si diferenciam-se pela numeração. BAPTISTA NETO, José. O Projeto de Lei que Institui a Comissão de Valores Mobiliários (CVM). Revista de Direito Mercantil, Industrial, Econômico e Financeiro, ano XIV, n. 20, 1975. p. 113.
} 
empréstimos dos Governos estrangeiros, em suma, os valores de Bolsa, que se tornaram tão numerosos em nosso tempo e que constituem uma parte da riqueza pública." 244

Em 1975, José Baptista Neto, em meio à discussão sobre o anteprojeto de lei que viria a ser a Lei n. 6.385/76, ao criticar o art. $3^{\circ}$ do anteprojeto, afirmou que a doutrina francesa classifica os títulos de crédito em effets de commerce e valeurs mobilières. ${ }^{245}$

Os effets de commerce, que pouco interessam a este trabalho e não foram definidos pelo autor, seriam títulos negociáveis que constatam a existência, a favor do portador, de uma dívida a curto prazo e que servem para o seu pagamento. Foram criados para a realização de operações comerciais. $^{246}$ São o cheque, a letra de câmbio, a nota promissória, os cupões, as promessas de compra e venda de ações (quando não puderem ser negociadas), etc. $^{247}$

Os valeurs mobilières, por sua vez, são definidos por José Baptista Neto. Segundo ele, a doutrina francesa considera valores mobiliários "títulos de renda periódica, emitidos em massa homogênea, e, por sua natureza, destinadas (sic) à grande circulação." ${ }^{248}$ Ripert, contudo, explica que o caráter distintivo dos valores mobiliários reside na natureza dos direitos neles contidos, que são, vale repetir, de sócios ou mutuários. ${ }^{249}$

Buchère decompõe ainda mais o conceito de valeur mobilière e o divide em (i) effets publics proprement dits e (ii) demais títulos que podem

\footnotetext{
${ }^{244}$ Tradução livre. No original: "[...] les incriptions de rentes sur l'État, les actions de la Banque de France, celles émises par les sociétés financières ou industrielles françaises ou étrangères, les obligations des villes ou départements, les titres d'emprunts des Gouvernements étrangers, en un mot les valeurs de Bourse, devenues si nombreuses à notre époque et qui constituent une partie de la fortune publique." BUCHÈRE, Ambroise. Traité Théorique et Pratique des Valeurs Mobilières et Effets Publics, $2^{\mathrm{a}}$ ed. Paris: Marescq Ainé, 1881. p. 1.

${ }^{245}$ Id., ibid. p. 112.

${ }^{246}$ RIPERT, Georges. Op. cit. p. 645.

${ }^{247}$ Id., ibid. p. 573.

${ }^{248}$ BAPTISTA NETO, José. Op. cit. p. 112.

${ }^{249}$ RIPERT, Georges. Op. cit. p. 573.
} 
ser cotados em bolsa. Os primeiros compreenderiam somente os "títulos de dívidas do Estado e aqueles emitidos pelas Sociedades, Companhias industriais ou comunidades de habitantes, autorizados por lei a contratar empréstimos públicos. ${ }^{250}$ Os últimos seriam considerados effets publics somente por denominação imprópria, derivada do uso dos negócios. ${ }^{251}$

Ary Oswaldo Mattos Filho bem explicou, em 1985, que

"[...] a doutrina francesa vincula o conceito de valor mobiliário ao de título associativo ou de empréstimo a longo prazo. De outro lado, parte da doutrina agrega ao critério temporal a necessidade de cotação em Bolsa de Valores."252

Com base na literatura sobre o tema, portanto, é possível identificar na doutrina francesa as seguintes características dos valores mobiliários: (i) a representação de direito de associação ou de empréstimo a longo prazo; (ii) a emissão em massa; e (iii) a possibilidade de cotação em bolsa. ${ }^{253}$

Com efeito, no anteprojeto de lei que veio a se tornar a Lei n. 6.385/76, entregue ao então Ministro da Fazenda Mário Henrique Simonsen pela comissão de juristas encabeçada por Alfredo Lamy Filho e José Luiz Bulhões Pedreira, os valores mobiliários foram assim definidos:

"Art. 3. - São valores mobiliários sujeitos ao regime desta Lei:

I- as ações, partes beneficiárias e debêntures, e os cupões desses títulos;

II - os bônus de subscrição, as cédulas de debêntures e os certificados de depósito de valores mobiliários;

III - quaisquer outros cuja negociação no mercado a Comissão de Valores Mobiliários submeta ao disposto no Capítulo III."

\footnotetext{
${ }^{250}$ Tradução livre. No original: “[...] les titres de créances sur l'État et ceux émis par les Sociétés, Compagnies industrielles ou communautés d'habitants, autorisées par une loi à contracter des emprunts publics." BUCHÈRE, Ambroise. Op. cit. p. 30.

${ }^{251}$ Id., ibid. p. 30.

252 MATTOS FILHO, Ary Oswaldo. O Conceito de Valor Mobiliário. Revista de Direito Mercantil, Industrial, Econômico e Financeiro, ano XXIV, n. 59, 1985. p. 37.

${ }^{253}$ À luz da doutrina apresentada neste trabalho, é certo que estas características não exaurem o conceito de valor mobiliário segundo a doutrina francesa. Se a doutrina trazida a este trabalho comprova algo, é precisamente a fluidez do conceito, oriunda da discordância dos autores sobre o tema. De todo modo, cumpre destacar que o Autor, ao apresentar este pequeno rol, procurou enumerar todas as características encontradas, não o menormaior denominador comum entre os autores, i.e., o conteúdo mínimo objeto de inegável consenso.
} 
Por sua vez, a Lei n. 6.385/76, conforme promulgada em 07.12.1976, conceituou valor mobiliário da seguinte maneira:

"Art $.2^{\circ}$ São valores mobiliários sujeitos ao regime desta Lei:

I - as ações, partes beneficiárias e debêntures, os cupões desses títulos e os bônus de subscrição;

II - os certificados de depósito de valores mobiliários;

III - outros títulos criados ou emitidos pelas sociedades anônimas, a critério do Conselho Monetário Nacional."

A definição, como se pode notar, foi pouco alterada. Na realidade, operou-se somente (i) a exclusão das "cédulas de debêntures" do inciso II, ${ }^{254}$ (ii) a restrição dos títulos do inciso III àqueles “criados ou emitidos pelas sociedades anônimas"; e (iii) a substituição da CVM pelo CMN como órgão definidor de quais títulos devem se submeter ao regime da Lei n. $6.385 / 76$.

Chama especial atenção a restrição operada no inciso II aos títulos "criados ou emitidos por sociedades anônimas". Isto teria levado Eizirik a identificar, em 1989, outro elemento no conceito de valeur mobilière, qual seja, o de ser de emissão de sociedades anônimas. ${ }^{255}$

Mais que isto, este simples fato levou importantes doutrinadores a entender que o conceito de valor mobiliário no direito brasileiro seria meramente instrumental e desprovido de compromisso dogmático. $\mathrm{O}$ legislador teria se preocupado com questões pragmáticas, de conveniência, não com o respeito a conceitos jurídicos. ${ }^{256}$

\footnotetext{
${ }^{254}$ São os títulos previstos no art. 72 da LSA.

255 EIZIRIK, Nelson. Aspectos Modernos do Direito Societário. Rio de Janeiro: Renovar, 1989. pp. 154-155.

${ }^{256} \mathrm{O}$ argumento pode ser encontrado tanto em EIZIRIK, Nelson et al. Op. cit. p. 27 quanto em LOBO, Carlos Augusto da Silveira. Advocacia de Empresas. Rio de Janeiro: Renovar, 2012. p. 176. A seguinte passagem sintetiza o argumento: "Portanto, a definição legal não tem, nem pretende ter, qualquer compromisso com um conceito geral de valor mobiliário. Aliás, também a doutrina renuncia à formulação de um conceito abstrato de valor mobiliário, talvez impossível, dado o seu caráter instrumental e a mobilidade das fronteiras do mercado, que tem por função delimitar. Acresce que a definição dos documentos admitidos à negociação no mercado de valores
} 
Ary Oswaldo Mattos Filho observa que a restrição do conceito de valores mobiliários a títulos emitidos por sociedades anônimas foi causada por influência política do Banco Central, que à época não queria ver sua competência sobre o mercado financeiro excessivamente reduzida. ${ }^{257}$

De fato, classificar determinado título como valor mobiliário produz o relevantíssimo efeito de colocar sua distribuição e negociação sob a esfera de competência da CVM. O legislador, então, pode alargar ou ajustar esse conceito conforme queira sujeitar determinados títulos (e, consequentemente, seus emissores, distribuidores, intermediários, etc.) ao regime da Lei n. 6.385/76.

Em essência, foi isto que ocorreu nos anos subsequentes à promulgação da lei. Eizirik et alii relatam que vários atos normativos do CMN e da CVM incluíram no rol de valores mobiliários do art. $2^{\circ}$ os vários outros títulos. $^{258}$

Foi somente em 2001 que a ampliação do conceito de valor mobiliário chegou a seu ápice. Em 14.02.2001 foi promulgada a Lei n. 10.198/01, conversão da Medida Provisória n. 2.110-40/01. ${ }^{259}$ Assim dispunha a lei:

“Art. $1^{\circ}$. Constituem valores mobiliários, sujeitos ao regime da Lei $n^{\circ} 6.385$, de 7 de setembro de 1976, quando ofertados publicamente, os títulos ou contratos de

mobiliários é questão de política legislativa, que se fundamenta mais em juízos de conveniência do que em conceitos." LOBO, Carlos Augusto da Silveira. Op. cit. p. 176. Na França a ideia de que os valores mobiliários devem ter um conceito geral, de contornos definidos com precisão, parece ter sido abandonada. É o que aponta BONNEAU, Thierry. Valeurs Mobilières et Titres Financiers em Droit Français. Revista de Direito Bancário e do Mercado de Capitais, n. 45, ano 12, jul. - set. 2009. pp. 198-206. A nova redação do art. L211-2 do Code Monétaire et Financier teria levado à diminuição da importância do conceito de valor mobiliário no direito francês, uma vez que o tornou uma categoria dentro do conceito de títulos financeiros (titres financiers). Os títulos agrupados por esta categoria seriam caracterizados por serem emitidos na execução de um contrato e por conter duas características em comum - a desmaterialização e a inscrição em conta.

${ }^{257}$ MATTOS FILHO, Ary Oswaldo. Op. cit. p. 32.

${ }^{258}$ EIZIRIK, Nelson et al. Op. cit. p. 54.

${ }^{259}$ Por sua vez, a Medida Provisória n. 2.110-40/01 foi a última de uma sucessão de Medidas Provisórias que teve início na 1.637/98, de 08.01.1998. 
investimento coletivo, que gerem direito de participação, de parceria ou de remuneração, inclusive resultante de prestação de serviços, cujos rendimentos advêm do esforço do empreendedor ou de terceiros."

Finalmente, em 31.10.2001, a Lei n. 10.303/01 pôs termo às várias modificações do conceito de valor mobiliário por meio da alteração do art. $2^{\circ}$ da Lei n. 6.385/76, cujo caput passou a ter a seguinte redação:

“Art. $2^{\circ}$ São valores mobiliários sujeitos ao regime desta Lei:

I- as ações, debêntures e bônus de subscrição;

II - os cupons, direitos, recibos de subscrição e certificados de desdobramento relativos aos valores mobiliários referidos no inciso II;

III - os certificados de depósito de valores mobiliários;

$I V$ - as cédulas de debêntures;

$V$ - as cotas de fundos de investimento em valores mobiliários ou de clubes de investimento em quaisquer ativos;

VI-as notas comerciais;

VII - os contratos futuros, de opções e outros derivativos, cujos ativos subjacentes sejam valores mobiliários;

VIII - outros contratos derivativos, independentemente dos ativos subjacentes; $e$ $I X$ - quando ofertados publicamente, quaisquer outros títulos ou contratos de investimento coletivo, que gerem direito de participação, de parceria ou de remuneração, inclusive resultante de prestação de serviços, cujos rendimentos advêm do esforço do empreendedor ou de terceiros."

Além da inclusão de vários títulos no rol do art. $2^{\circ}$, duas alterações são dignas de nota: (i) a remoção da competência do CMN para incluir títulos emitidos por sociedades anônimas no rol do art. $2^{\circ}$, e (ii) a adoção, no inciso IX, de redação praticamente idêntica à do $\operatorname{art.} 1^{\circ}$ da Lei n. $10.198 / 01 .^{260}$

Numa guinada de política legislativa, a lei, sem querer abandonar o conceito francês originalmente adotado, incorporou o conceito norte americano de security. Trata-se da adoção de modelo verdadeiramente híbrido, que será abordado a seguir.

${ }^{260}$ As sucessivas alterações da noção de valor mobiliário na Lei n. 6.385/76 são relatadas em EIZIRIK, Nelson et al. Op. cit. pp. 52-59. 


\subsubsection{Collective investment schemes: o inciso interminável da Lei} n. $6.385 / 76$

No modelo norte americano de regulação do mercado de capitais, a noção de security é abrangente, em oposição ao conceito mais estreito de valor mobiliário adotado pelo RU e pela Bélgica, Holanda, Alemanha e França. ${ }^{261}$

O conceito de security não teve origem no Securities Act de $1933 .{ }^{262}$ Na realidade, como já dito, a primeira blue sky law foi promulgada no Estado do Kansas em 1911, e criou a primeira autoridade reguladora de valores mobiliários. A utilização do termo pelo legislador federal norte americano de 1933 se baseou em seu emprego pela legislação a nível estadual. $^{263}$

$\mathrm{Na}$ realidade, a característica essencial da security é que ela representa um esquema de investimento cujos rendimentos são percebidos como fruto do trabalho de terceiros (no qual não interfere o investidor).

A respeito disso, a Suprema Corte dos EUA já teve a oportunidade de se pronunciar diversas vezes. São mais marcantes, contudo, os casos SEC v. Joinder Leasing Corp. (1943) e SEC v. Howey (1946).

\footnotetext{
${ }^{261}$ EIZIRIK, Nelson. Aspectos Modernos do Direito Societário. Rio de Janeiro: Renovar, 1992. p. 153.

${ }^{262}$ De acordo com a Section 2(a)(1) do Securities Act, security significa "any note, stock, treasury stock, security future, security-based swap, bond, debenture, evidence of indebtedness, certificate of interest or participation in any profit-sharing agreement, collateral-trust certificate, preorganization certificate or subscription, transferable share, investment contract, voting-trust certificate, certificate of deposit for a security, fractional undivided interest in oil, gas, or other mineral rights, any put, call, straddle, option, or privilege on any security, certificate of deposit, or group or index of securities (including any interest therein or based on the value thereof), or any put, call, straddle, option, or privilege entered into on a national securities exchange relating to foreign currency, or, in general, any interest or instrument commonly known as a "security", or any certificate of interest or participation in, temporary or interim certificate for, receipt for, guarantee of, or warrant or right to subscribe to or purchase, any of the foregoing."

${ }^{263}$ MATTOS FILHO, Ary Oswaldo. Op. cit. p. 40.
} 
Em SEC v. Joiner Leasing Corp., a C. M. Joiner Leasing Corporation decidiu financiar a perfuração de um poço de petróleo em McCulloch County, Texas. O esquema de financiamento encontrado pela companhia foi a venda de pequenas porções de terra nos arredores do poço de petróleo por meio de prospectos enviados pelos correios a aproximadamente 1000 pessoas ao redor dos EUA. ${ }^{264}$

O material enviado aos ofertados não mencionava as condições que eles encontrariam nos terrenos caso tentassem perfurar poços de petróleo, tampouco eventuais custos incorridos - informava, ao invés disso, que a Joiner Company estava perfurando um poço de petróleo para testar a possibilidade de as terras vendidas serem sítios de produção de petróleo. $\mathrm{O}$ material enfatizava que se tratava de um investimento, de uma participação em um empreendimento.

Nas palavras do Juiz Jackson:

\begin{abstract}
"Sua proposta era vender documentos que ofereciam ao comprador a chance, sem atraso ou custos adicionais, de participar de descobertas que poderiam advir de um empreendimento de exploração já existente. A perfuração deste poço não era um fenômeno desconectado ou fora do controle ao qual os vendedores apontavam meramente para indicar as possibilidades dos arrendamentos ofertados. O empreendimento de exploração foi costurado nesses arrendamentos, em um sentido tanto econômico quanto jurídico; o empreendimento de perfurar um poço corre por toda a transação como o fio sobre o qual se pendurou as miçangas de todos. Um contrato para perfurar foi a contraprestação pela qual Anthony se habilitou a adquirir arrendamentos sobre 4.700 acres. Foi tomando este contrato como pressuposto que a Joiner adquiriu 3.002 dos acres, deixando a Anthony aproximadamente 1.700 acres por sua própria conta e risco. E foi este empreendimento de perfurar o poço que permitiu à Joiner financiá-lo por meio da venda de acres de terra." 265
\end{abstract}

\footnotetext{
264 SUPREME COURT OF THE UNITED STATES OF AMERICA. Securities Exchange Commission v. C. M. Joiner Leasing Corporation Co. et al. US Report, vol. 320. p. 346.

265 "Their proposition was to sell documents which offered the purchaser a chance, without undue delay or additional cost, of sharing in discovery values which might follow a current exploration enterprise. The drilling of this well not an unconnected or uncontrolled phenomenon to which salesmen pointed merely to show the possibilities of the offered leases. The exploration enterprise was woven into these leaseholds, in both an economic and a legal sense; the undertaking to drill a well runs through the whole transaction as the thread on which everybody's beads were strung. An agreement to drill formed the consideration upon which Anthony was able to collect leases on
} 
A perquirição sobre o direito do adquirente de compelir a Joiner a perfurar o poço de teste seria irrelevante para a questão, uma vez que os termos da oferta corporificam uma obrigação implícita para completar a perfuração. Os pagamentos estavam estruturados de forma a serem feitos quando se completasse a perfuração - tratava-se, portanto, de um investment contract nos termos do Securities Act de 1933. O adquirente estaria pagando tanto pelo arrendamento da terra quanto por um projeto. ${ }^{266}$

O interesse econômico na perfuração foi o que deu aos documentos ofertados a maior parte de seu valor e toda a sua atratividade. A negociação destes documentos continha todos os males inerentes às transações com securities, males estes que o Securities Act almejaria acabar. O propósito da lei seria o de incluir no conceito de security "vários documentos nos quais há negociação comum para especulação ou investimento." ${ }^{267}$ Entendeu-se, sobretudo, que não se poderia ler os termos mais genéricos da definição de security de forma a restringi-lo somente aos mais restritos. ${ }^{268}$

Quanto à questão específica de aluguéis de petróleo e gás, a Corte entendeu que o legislador quis deixar de fora contratos comumente celebrados pela indústria do petróleo e do gás sem, contudo, deixar de incluir aqueles que são mais utilizados para propósitos especulativos. ${ }^{269}$

Por fim, a Corte entendeu que era irrelevante o contrato de aluguel, ser caracterizado, sob a lei do Texas, como um interest in real estate, pois pouco importaria a natureza do instrumento utilizado, e sim "os termos da

\footnotetext{
4,700 acres. It was in return for assumption of this agreement that Joiner got 3,002 of the acres, leaving 1,700 acres for his trouble. And it was his undertaking to drill the well which enabled Joiner to finance it by the sale of acreage." Id., ibid. pp. 348-349.

${ }^{266}$ Id., ibid. p. 349

267 Tradução livre. No original: “[...] many documents in which there is common trading for speculation or investment.” Id., ibid. p. 351.

${ }^{268}$ Id., ibid. p. 350.

${ }^{269}$ Id., ibid. p. 352.
} 
oferta, o plano de distribuição, e os atrativos econômicos dispostos no prospecto. $" 270$

Em SEC v. Howey, a questão residia em decidir se consistia um contrato de investimento (investment contract) a oferta de venda de glebas para plantação de laranjas associada a um contrato para o cultivo e venda dos frutos e posterior remessa do resultado líquido para o investidor. ${ }^{271}$

Neste caso o significado da expressão "investment contract" foi retomado, bem como o método por meio do qual interpretá-la.

Para a Suprema Corte, o teste para se identificar um investment contract consistiria em identificar este esquema com um "investimento de dinheiro em um empreendimento comum com lucros advindo somente do trabalho de terceiros". ${ }^{272}$ Seria irrelevante saber se o investimento teria natureza especulativa ou não; ou mesmo se a propriedade vendida tinha ou não um valor intrínseco.

No esquema de investimento do presente caso, The Howey Company era a proprietária das glebas de terra e Howey-in-the-Hills Service, Inc. prestava os serviços relacionados ao cultivo e venda das laranjas. O contratante era livre para escolher a empresas que quisesse para prestar os serviços, mas a superioridade da Howey-in-the-Hills Service, Inc. recebia destaque. Ao final de um período de três anos (terminando em 31.05.1943), $85 \%$ das terras vendidas estavam relacionadas a serviços de cultivo prestados pela Howey-in-the-Hills Service, Inc. O preço do acre de terra era uniforme, variando somente de acordo com o tempo decorrido desde a

\footnotetext{
270 Tradução livre. No original: "[...] the terms of the offer, the plan of distribution, and the economic inducements held out to the prospect." Id., ibid. p. 353.

${ }^{271}$ SUPREME COURT OF THE UNITED STATES OF AMERICA. Securities Exchange Commission v. W. J. Howey Co. et al. US Report, vol. 328. p. 295.

${ }^{272}$ Tradução livre. No original: "[...] investment of money in a common enterprise with profits to come solely from the efforts of others". Id., ibid. p. 293.
} 
plantação das laranjas. O contrato de serviços, por sua vez, dava à Howeyin-the-Hills Service, Inc. posse plena e integral da terra. Pelo contrato, a companhia possuía total discrição e autoridade quanto ao plantio, colheita e venda das colheitas. Ainda sob o contrato, o proprietário da terra não possuía o direito aos frutos da plantação - sem a autorização da companhia prestadora de serviços, não poderia vender os frutos no mercado. Todo o resultado seria acumulado pelas duas companhias e depois distribuído aos contratantes, que, em sua maioria, foram atraídos pela oportunidade de lucros. ${ }^{273}$

A publicidade deste investimento era feita em um hotel operado pela The Howey Company e de sua propriedade em uma parte adjacente às plantações. A publicidade do hotel chamava atenção dos clientes para as plantações nas adjacências e eles, enquanto faziam um passeio pelos entornos do hotel, eram informados que elas estavam à venda. Caso tivessem interesse, poderiam se engajar em negociações. ${ }^{274}$

Segundo o Juiz Murphy, a seção 2(1) do Securities Act de 1933 define security "para incluir os documentos comumente conhecidos como para especulação ou investimento". Contudo, a definição inclui também securities de um caráter mais variável, permitindo que se inclua, se for o caso, o contrato de venda de terras, o contrato de prestação de serviços e a escritura de compra e venda na categoria de "investment contract". ${ }^{275}$

Segundo o Juiz Murphy, o termo foi interpretado extensivamente de forma a permitir total proteção aos investidores. Investment contracts seriam contratos ou esquemas para a colocação de capital ou desembolso de dinheiro de um modo cuja intenção é assegurar renda ou lucro com seu emprego. A intenção do Congresso ao incluir a expressão "investment

\footnotetext{
${ }^{273}$ Id., ibid. p. 295-296.

${ }^{274}$ Id., ibid. pp. 296-297.

${ }^{275}$ Id., ibid. pp. 297-298.
} 
contract" dentro do conceito de security teria sido a de incorporar tal definição ao Securities Act de $1933 .^{276}$

Segundo esta definição ampla, é irrelevante se as participações no empreendimento são documentadas em certificados formais ou se são interesses nos ativos físicos empregados na empresa. Segundo Murphy, este teria sido o entendimento subjacente à decisão da Suprema Corte em SEC. v. Joiner Corp. e permitiria o full and fair disclosure almejado pela lei. $^{277}$

No caso concreto, as duas companhias ofereceram uma oportunidade para aportar dinheiro e participar dos lucros em um empreendimento de cultivo de frutas administrado pelas próprias companhias e cuja propriedade é parcialmente delas. As ofertas eram dirigidas a pessoas que viviam em locais distantes e não tinham participação no plantio, colheita ou venda das frutas, tampouco qualquer intenção de ocupar as terras. Seu investimento foi atraído somente pela oportunidade de lucros. Na realidade, o contrato de venda das terras e a respectiva escritura na realidade eram um expediente útil para as companhias saberem a proporção segundo a qual deveriam alocar os lucros do empreendimento. ${ }^{278}$

Em suma, todos os elementos de um negócio que objetiva o lucro estariam presentes:

\footnotetext{
"Os investidores fornecem o capital e participam das receitas e lucros; os promotores do empreendimento o administram, controlam e operam. Daí decorre que os arranjos por meio dos quais os interesses dos investidores se manifestam envolvem contratos de investimento, independentemente da terminologia jurídica sob a qual tais contratos estão ocultados. ${ }^{, 279}$
}

\footnotetext{
${ }^{276}$ Id., ibid. p. 298.

${ }^{277}$ Id., ibid. p. 299.

${ }^{278}$ Id., ibid. 299-300.

279 "The investors provide the capital and share in the earnings and profits; the promoters manage, control and operate the enterprise. It follows hat the arrangements whereby the
} 
Eizirik et alii comentam que são quatro os requisitos de enquadramento no conceito de security estebelecidos em SEC v. Howey: (i) investimento em dinheiro; (ii) empreendimento comum; (iii) expectativa de lucro; e (iv) unicamente dos esforços dos outros. ${ }^{280}$ Contudo, observam que nem sempre os tribunais observam todos os requisitos da Howey definition para definir um título como valor mobiliário. ${ }^{281} \mathrm{Na}$ visão deste Autor, ela é, de todo modo, representativa da possibilidade de dilação e contração do conceito de valor mobiliário na Lei n. 6.385/76, uma vez que esta adotou uma definição semelhante no inciso IX do art. $2^{\circ}$.

Essa pode ser a primeira conclusão que se tira deste pequeno excurso à noção de valor mobiliário na Lei n. 6.385/76. O conceito é instrumental e modifica-se de acordo com as necessidades do legislador de colocar determinados títulos dentro ou fora do quadro regulatório e da competência da CVM. A incorporação do conceito norte americano de security traz uma abrangência muito maior ao art. $2^{\circ}$, de forma que caberá, em última análise, aos órgãos julgadores decidirem, em cada caso, se se trata de valor mobiliário ou não. Evidentemente, este ônus argumentativo somente estará presente nos casos fronteiriços, como em SEC v. Howey.

Em segundo lugar: à luz do que se demonstrou até aqui não há dúvida que as companhias que emitem os títulos descritos no art. $2^{\circ}$ da ICVM 480 são emissoras de valores mobiliários para fins do art. $2^{\circ}$ da Lei n. 6.385/76. Desta forma, a ICVM 480, ao determinar que as companhias

\footnotetext{
investors' interests are made manifest involve investment contracts, regardless of the legal terminology in which such contracts are clothed." Id., ibid. p. 300. O Juiz Frankfurter proferiu voto dissidente. $\mathrm{Na}$ parte que toca a este estudo, entendeu que o fato (i) de a venda das terras estar dissociada do contrato de prestação de serviços, (ii) de os contratantes terem a liberdade - e de a terem exercido em alguns casos - de não contratar os serviços da Howey-in-the-Hills Service, Inc., e (iii) de os contratantes terem todos inspecionado as terras antes de comprá-las levaria a um distanciamento do conceito de security do Securities Act de 1933. Não se deveria, a seu ver, estender o Securities Act a casos inocentes somente porque formas pervertidas deste ato estariam enquadradas neles. Id., ibid. p. 302.

${ }^{280}$ EIZIRIK, Nelson et al. Op. cit. p. 35.

${ }^{281}$ Id., ibid. p. 36.
} 
que emitem títulos elencados no art. $2^{\circ}, \S 1^{\circ}$, (categoria A) preencham o item 13.11 do Anexo 24, age dentro de sua competência assegurada pela Lei n. 6.385/76. De forma geral, o Autor ousa dizer que o item 13 do Anexo 24 não extrapola a competência da CVM.

\subsection{Juridicidade dos atos normativos da CVM}

Uma vez que se define com precisão o conceito de valor mobiliário, deve-se necessariamente concluir que a competência normativa da CVM abarca indubitavelmente a matéria versada pela ICVM 480 e pela Deliberação n. 560. Contudo, a discussão a respeito da competência da CVM não se limita à noção de valor mobiliário. Há também a discussão a cerca da constitucionalidade dos atos normativos da CVM e das demais agências reguladoras.

Como será logo demonstrado, para fins desta discussão especificamente é correto tratar a CVM como agência reguladora - sujeita, portanto, à mesma críticas e ao mesmo respaldo doutrinários. Em outras palavras, a discussão sobre o poder normativo da CVM se insere em outra consideravelmente mais ampla - a da constitucionalidade do poder normativo das agências reguladoras brasileiras.

Como já foi esboçado, para fins desta discussão, a CVM será considerada uma agência reguladora. Esta parece ser a tendência na doutrina moderna, encabeçada por Nelson Eizirik et alli. ${ }^{282}$ A posição é compartilhada por Celso Antonio Bandeira de Mello, que nota que a CVM possui funções de índole equivalente às das agências reguladoras, não tendo, contudo, recebido o nome "agência". ${ }^{283}$ Maria Sylvia Zanella di Pietro observa agudamente que o fenômeno de definição de conceitos jurídicos indeterminados por entes da administração pública que exercem

\footnotetext{
${ }^{282}$ EIZIRIK, Nelson et al. Op. cit. pp. 266-271.

${ }^{283}$ MELLO, Celso Antonio Bandeira de. Curso de Direito Administrativo. $28^{\text {a }}$ ed. revista e atualizada. São Paulo: Malheiros, 2011. p. 171.
} 
função normativa já vinha de longa data, porém somente suscitou debates doutrinários quando foram criados órgãos com a denominação de "agência reguladora". 284

O Autor não pode deixar de notar que há controvérsia acerca do caráter independente da CVM enquanto agência reguladora. Explica Alexandre dos Santos Aragão que as características das agências reguladoras independentes no modelo brasileiro são (i) a autonomia orgânica e (ii) a autonomia funcional. A primeira o autor define como a vedação à demissibilidade ad nutum dos seus dirigentes; e a segunda o autor define como a inexistência de ingerência hierárquica da administração central (Presidente da República e Ministérios) sobre os seus atos decisórios. ${ }^{285}$

Quando de sua criação, a CVM não possuía nenhuma das duas modalidades de autonomia. $\mathrm{O}$ art. $6^{\circ}, \S 1^{\circ}$, da Lei n. 6.385/76, era expresso ao dispor que seus diretores poderiam ser demitidos ad nutum. ${ }^{286}$

Tentou-se alterar tal situação com a promulgação da Lei n. 10.303/76, que, contudo, recebeu veto parcial do Presidente da

\footnotetext{
${ }^{284}$ MELLO, Celso Antonio Bandeira de. Op. cit. p. 171. PIETRO, Maria Sylvia Zanella di. Op. cit. p. 12.

285 ARAGÃO, Alexandre dos Santos. Agências Reguladoras e a Evolução do Direito Administrativo Econômico. Rio de Janeiro: Forense, 2009. p. 264.

286 "Art. $6^{\circ}$ A Comissão de Valores Mobiliários será administrada por um presidente e quatro diretores, nomeados pelo Presidente da República, dentre pessoas de ilibada reputação e reconhecida competência em matéria de mercado de capitais.

$\S 1^{\circ} \mathrm{O}$ presidente e os diretores serão substituídos, em suas faltas, na forma do regimento interno, e serão demissiveis ad nutum.

$[\ldots] "$

A redação é curiosamente diferente daquela do anteprojeto da lei:

"Art. 5. ${ }^{\circ}$ - Fica criada a Comissão de Valores Mobiliários, que será constituída de um presidente e quatro membros, nomeados pelo Presidente da República, após aprovação pelo Senado Federal, dentre brasileiros de ilibada reputação e notório conhecimento em matéria de operações no mercado de capitais ou de administração de empresas.

Parágrafo 1. ${ }^{\circ}$ - O presidente será demissível ad nutum e os demais membros terão mandato de quatro anos, podendo ser reconduzidos. [...]"
} 
República, inclusive na parte em que alterava o art. $6^{\circ} .^{287}$ De acordo com Julian Fonseca Peña Chediak, a dúvida da Presidência da República acerca da constitucionalidade formal de certos aspectos da reforma promovida pela Lei n. 10.303/01 fez com que o Executivo e o Legislativo entrassem em concerto: ao mesmo tempo que o chefe do Executivo vetaria certos dispositivos da Lei n. 10.303/01, os colocaria na Medida Provisória n. 8/01 e no Decreto n. 3.995/01. Os três diplomas - a lei, o decreto e a medida provisória - foram editados no mesmo dia e alteraram simultaneamente a Lei n. $6.385 / 76^{288}$

Pouco tempo depois, a Medida Provisória n. 08/01 foi convertida na Lei n. 10.411/01. A alteração do art. $6^{\circ}$ deu-lhe a seguinte redação, que persiste até hoje:

“Art. $6^{\circ}$ A Comissão de Valores Mobiliários será administrada por um Presidente e quatro Diretores, nomeados pelo Presidente da República, depois de aprovados pelo Senado Federal, dentre pessoas de ilibada reputação e reconhecida competência em matéria de mercado de capitais.

$\S 1^{\circ} O$ mandato dos dirigentes da Comissão será de cinco anos, vedada a recondução, devendo ser renovado a cada ano um quinto dos membros do Colegiado.

$\S 2^{\circ}$ Os dirigentes da Comissão somente perderão o mandato em virtude de renúncia, de condenação judicial transitada em julgado ou de processo administrativo disciplinar.

$[\ldots] "$

\footnotetext{
${ }^{287}$ De acordo com a lei antes do veto presidencial, assim deveria ser a nova redação do art. $6^{\circ}$, caput e $\S 1^{\circ}$, da Lei n. 6.385/76:

"Art. 6. ${ }^{\circ}$ A Comissão de Valores Mobiliários será administrada por um Presidente e 4 (quatro) Diretores, nomeados pelo Presidente da República, depois de aprovados pelo Senado Federal, dentre pessoas de ilibada reputação e reconhecida competência em matéria de mercado de capitais.

$\S 1^{\circ}$ O mandato dos dirigentes da Comissão será de 5 (cinco) anos, vedada a recondução, devendo ser renovado a cada ano 1/5 (um quinto) dos membros do Colegiado.

[...]"

De forma resumida, as razões do veto à nova redação do art. $6^{\circ}$ foram as seguintes: (i) a iniciativa de leis que disponham sobre servidores públicos é exclusiva do Presidente da República por força do art. $61, \S 1^{\circ}$, inciso II, alínea $c$, da CRFB/88; e (ii) a regra da "quarentena" prevista no $\S 5^{\circ}$, além de violar a iniciativa do Presidente, trazia despesas desnecessárias.

${ }^{288}$ CHEDIAK, Julian Fonseca Peña. A Reforma do Mercado de Valores Mobiliários. In: LOBO, Jorge (coord.) Reforma da Lei das Sociedades Anônimas: inovações e questões controvertidas da Lei no 10.303, de 31.10.2001. Rio de Janeiro: Forense, 2002. pp. 527-528.
} 
A mesma reforma promovida pela Medida Provisória n. 08/01 (posterior Lei n. 10.411/01) conferiu nova redação ao art. $5^{\circ}$ da Lei n. 6.385/76, que passou a deixar claro que a CVM seria, a partir de então,

"entidade autárquica em regime especial, vinculada ao Ministério da Fazenda, com personalidade jurídica e patrimônio próprios, dotada de autoridade administrativa independente, ausência de subordinação hierárquica, mandato fixo e estabilidade de seus dirigentes, e autonomia financeira e orçamentária."

Estava resolvida a questão da autonomia orgânica: nenhum dos dirigentes da CVM poderia ser exonerado ad nutum. Contudo, a questão da autonomia funcional da CVM estaria, na visão de Aragão, longe de resolvida. Isto porque o art. $11, \S 4^{\circ}$, da Lei n. 6.385/76 ainda permite a interposição de recurso ao CRSFN das penalidades aplicadas no âmbito dos processos administrativos sancionadores. Uma vez que o CRSFN é órgão integrante da estrutura do Ministério da Fazenda, não se poderia classificar a CVM como agência reguladora independente. ${ }^{289}$

O doutrinador José Waldecy Lucena também defende que a CVM seja agência reguladora. Contudo, diverge de Alexandre Santos de Aragão quanto à independência da mesma. Para o primeiro, o recurso interposto para o CRSFN seria hierárquico impróprio, segundo classificação de Bandeira de Mello, uma vez que interposto perante pessoa jurídica de direito público distinta daquela que proferiu a decisão e cuja estrutura não a encarta. Com efeito, o CRSFN não encarta a CVM nem o BACEN em sua estrutura e é perante ele (o CRSFN) que os recursos do art. $11, \S 4^{\circ}$, da Lei n. 6.385/76 são interpostos. Desta forma, a conclusão é que não se pode falar em ausência de autonomia funcional - a CVM é agência reguladora independente. ${ }^{290}$

\footnotetext{
${ }^{289}$ ARAGÃO, Alexandre Santos de. Op. cit. pp. 303-304.

${ }^{290}$ LUCENA, José Waldecy. Das Sociedades Anônimas: Comentários à Lei, v. 1. Rio de Janeiro: Renovar, 2009. pp. 137-140.
} 
A verdade é que, caracterizada ou não a independência da CVM, fica ainda assim nítida sua função reguladora, posto que dotada, segundo Aragão, dos três poderes inerentes à regulação: "aquele de editar a regra, o de assegurar a sua aplicação e o de reprimir as infrações. "291 Sobre este aspecto concordam autores como Otavio Yazbek ${ }^{292}$ e Diogo de Figueiredo Moreira Neto. $^{293}$

A discussão sobre a independência da CVM, embora interessante, não tem grande relevância para este trabalho. É satisfatório definir a CVM como agência reguladora para que se possa aplicar-lhe as várias teorias sobre o poder normativo desta figura jurídica. O caráter da independência não é relevante para tal propósito.

Por fim, é de se ressaltar que o vocábulo "agência", pelo menos para o Direito, não tem aqui um significado específico e que traga consigo maiores consequências jurídicas. Da mesma forma que se emprega a expressão "agência reguladora", poder-se-ia empregar "entidade reguladora". 294

O que o Autor fará a seguir será examinar a crítica feita ao poder normativo das agências reguladoras criadas na década de 1990 e aplicá-la ao caso da CVM. A juridicidade dos atos administrativos normativos é

\footnotetext{
${ }^{291}$ ARAGÃO, Alexandre Santos de. Op. cit. p. 24.

292 "[...] a expressão regulação engloba atividades estatais que vão da criação de normas, passando pela sua implementação por meio de determinados atos administrativos e pela fiscalização do seu cumprimento, até e a punição dos infratores. $O$ regulador exerce um poder normativo, um poder executivo e um poder "parajudicial"." YAZBEK, Otavio. Regulação do Mercado Financeiro e de Capitais. $2^{\mathrm{a}}$ ed. ampliada. Rio de Janeiro: Elsevier, 2009. p. 184.

293 "A atividade dos institutos que conformam os subsistemas de harmonização é a função reguladora, que, não obstante o étimo, que a aproxima da voz vernácula regra, o que traz a ideia de normatividade, é mais que isso: é um híbrido de atribuições de variadas natureza, informativas, fiscalizadoras e negociadoras, mas, também, normativas, gerenciais, arbitradoras e sancionadoras.

[...]

Em suma, agora com remissão à classificação mais difundida, essa função reguladora vale-se de um complexo de funções clássicas, administrativas, normativas $e$ judicantes, variando apenas o método decisório que as combinará." MOREIRA NETO, Diogo de Figueiredo. Mutações do Direito Público. Rio de Janeiro: Renovar, 2006. pp. 392-393.

${ }^{294}$ Cf. ARAGÃO, Alexandre Santos de. Op. cit. p. 270.
} 
posta em questão sobretudo diante dos princípios da separação dos poderes e da legalidade. Contra este poder normativo teriam se insurgido vários autores; outros não teriam identificado nele maiores problemas; ainda outros teriam feito elaboradas construções teóricas para justificá-lo. O Autor passará a explorar estas vertentes abaixo, iniciando (i) pela doutrina contrária ao poder normativo da CVM. Após, explorará (ii) a doutrina favorável a esse poder. Por fim, o Autor apresentará (iii) sua posição e concluirá o Capítulo aplicando-a ao caso da ICVM 480 e da Deliberação n. $560 .^{295}$

Deve-se ressaltar que, como alguns autores já notaram, a controvérsia se dá no plano meramente teórico. Durante décadas entidades com poderes reguladores sobre os mercados financeiro e de capitais têm atuado, emitindo incontáveis atos normativos que criam, alteram ou extinguem obrigações - sem mencionar nos demais mercados regulados por agências reguladoras, como os de telefonia, eletricidade e saúde suplementar. A consequência prática, para o nosso ordenamento e para o cotidiano de todo o País, da declaração da inconstitucionalidade de todos esses atos seria inconcebivelmente ampla e profunda.

\subsubsection{A tese contrária}

A tese contrária ao poder normativo da CVM e de demais agências reguladoras é muitas vezes identificado com uma corrente denominada "tradicionalista" dentro do direito administrativo. Talvez o autor mais

\footnotetext{
${ }^{295}$ Pela grande simplicidade e clareza, o Autor escolheu apresentar o tema na mesma ordem que em que apresentado em LUCENA, José Waldecy. Das Sociedades Anônimas: Comentários à Lei, v. 1. Rio de Janeiro: Renovar, 2009. pp. 143-155. Contudo, o Autor faz a ressalva que acredita que identificar as teses tradicionais com aquelas contrárias ao poder normativo da CVM e as modernas como favoráveis é inapropriado. O critério eleito não pode ser o cronológico uma vez que o poder normativo da CVM já era defendido por alguns autores na década de 1970; tampouco pode se pautar na modernidade das construções doutrinárias, uma vez que há trabalhos manifestando-se favoravelmente ao poder normativo da CVM com base em construções doutrinárias antigas. $\mathrm{Na}$ realidade, não há critério ou classificação adequado para uma discussão tão heterogênea, de forma que o Autor aqui classifica com o mero propósito de simplificar. Quando devidas, as ressalvas serão feitas.
} 
representativo desta corrente em nossos dias seja Celso Antonio Bandeira de Mello. O trecho abaixo, embora longo, é uma ilustração vívida da posição:

\begin{abstract}
"Considera-se que há delegação disfarçada e inconstitucional, efetuada fora do procedimento regular, toda vez que a lei remete ao Executivo a criação das regras que configuram o direito ou que geram a obrigação, o dever ou a restrição à liberdade.

[...]

Entre nós, este procedimento abusivo, inconstitucional e escandaloso foi praticado inúmeras vezes e do modo mais flagrante possível. Nisto se revela o profundo descaso que, infelizmente, nossos legisladores têm tido na mantença das prerrogativas do Poder em que se encartam, demonstrando, pois, um cabal desapreço pela Constituição e - pior que isto - olímpica indiferença pela salvaguarda dos direitos e garantias dos cidadãos.

Assim, inúmeras são as leis que deferem, sic et simpliciter, a órgãos colegiais do Executivo - como ao Conselho Monetário Nacional, por exemplo - o poder de expedir decisões ("resoluções") cujo conteúdo só pode ser o de lei."296
\end{abstract}

Funda-se o autor no poder regulamentar do Presidente da República, conforme estatuído no art. 84, inciso IV, da CRFB/88. ${ }^{297}$ Baseia-se, igualmente, na noção de que seriam indelegáveis as funções exercidas pelos três poderes, e que este princípio estaria implícito no art. $2^{\circ}$ da $\mathrm{CRFB} / 88$, que trata da separação de poderes. ${ }^{298}$

A ideia não foi concebida por este autor, tampouco é nova. Em 1930 escrevia, póstumo, Hauriou: “O poder regulamentar não é delegado pelo

\footnotetext{
${ }^{296}$ Id., ibid. pp. 358-359.

297 “Art. 84. Compete privativamente ao Presidente da República:

$[\ldots]$

VI - sancionar, promulgar e fazer publicar as leis, bem como expedir decretos e regulamentos para sua fiel execução;

$[\ldots]^{\prime \prime}$

O Autor pondera se tratar o fenômeno da delegação normativa, ou legislativa, se deu por causa de prática do STF relatada por Victor Nunes Leal: "No Império e na Primeira República, foi assunto de árduas controvérsias, mas a nossa prática política aceitou e tolerou o uso das delegações legislativas. Muitas vezes o Supremo Tribunal Federal, como veremos mais adiante, afirmou a nulidade das delegações, mas contornou a situação, interpretando extensivamente o poder regulamentar do Presidente da República." LEAL, Victor Nunes. Problemas de Direito Público e Outros Problemas. vol. 1. Brasília: Imprensa Nacional, 1999. pp. 93-94. O artigo Delegações Legislativas foi originalmente publicado na Revista de Direito Administrativo, vol. 5, jul. 1946. p. 378.

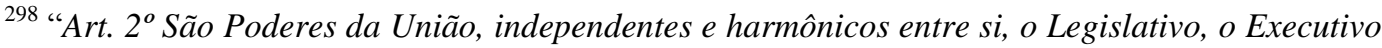
e o Judiciário."
} 
poder legislativo; o próprio princípio da separação dos poderes se opõe à ideia de delegação [...]"299

$\mathrm{Na}$ concepção clássica, o regulamento cumpriria a função de operacionalização técnica da lei, visando a atingir dois objetivos: (i) o de estabelecer procedimentos para se concretizar a lei, ou (ii) o de concretizar e especificar casos em que a lei deve ser aplicada, devido a seu caráter genérico e abstrato.

Posição semelhante pode ser encontrada em Hely Lopes Meirelles:

"O poder regulamentar é a faculdade de que dispõem os Chefes de Executivo (Presidente da República, Governadores e Prefeitos) de explicar a lei para sua correta execução, ou de expedir decretos autônomos sobre matéria de sua competência ainda não disciplinada por lei. É um poder inerente e privativo do Chefe do Executivo $(C F$, art. 84, IV), e, por isso mesmo, indelegável a qualquer subordinado.

[...]

Regulamento é ato administrativo geral e normativo, expedido privativamente pelo Chefe do Executivo (federal, estadual ou municipal), através de decreto, com o fim de explicar o modo e forma de execução da lei (regulamento de execução) ou prover situações não disciplinadas em lei (regulamento autônomo ou independente)." ${ }^{300}$

A vedação à delegação presente na Constituição impediria que a lei delegasse ao Executivo o poder de criar, alterar ou extinguir direito ou obrigação. Fazer isto caberia somente à lei em sentido formal. Se do texto da lei não decorre claramente tal criação, alteração ou extinção do direito, não pode o regulamento operá-las, sob pena de inconstitucionalidade do mesmo.

\footnotetext{
${ }^{299}$ Tradução livre. No original: "Le pouvoir réglementaire n'est don pas délégué par le pouvoir législatif; le principe même de la séparation des pouvoirs s'oppose à l'idée de délégation [...]" HAURIOU, Maurice. Précis Élémentaire de Droit Constitutionnel. $2^{\mathrm{a}}$ ed. Paris: Sirey, 1930. p. 152.Op. cit. p. 152.

${ }^{300}$ MEIRELLES, Hely Lopes. Direito Administrativo Brasileiro. $25^{\mathrm{a}}$ ed. atualizada por Eurico de Andrade Azevedo, Délcio Balestero Aleixo e José Emmanuel Burle Filho. São Paulo: Malheiros, 2000. pp. 118-119.
} 
Bandeira de Mello, na visão deste Autor, consegue demonstrar com razoável sucesso o valor de seu argumento: caso a lei delegue ao Poder Executivo o poder de legislar, a regra contida no art. $5^{\circ}$ da $\mathrm{CRFB} / 88$, de que "ninguém será obrigado a fazer ou deixar de fazer alguma coisa senão em virtude de lei" perderá por completo seu caráter de garantia constitucional. Os cidadãos passariam a se ver obrigados a obedecer a comandos ora legais, ora regulamentares.

Sua percepção da vedação a delegação de poderes, contudo, pode - e talvez deva ser - temperada com as observações de Victor Nunes Leal sobre o assunto. Segundo o autor, não constitui a indelegabilidade de poderes a maior garantia do cidadão contra o Estado autoritário. Lembra ele que

"[f]oi na plena vigência da Constituição de 1934 que o parlamento votou a lei de segurança nacional, aprovou as emendas constitucionais, criou o Tribunal de Segurança e permitiu a decretação do estado de guerra em todo o território nacional, armando, assim, o Presidente de todos os recursos que lhe permitiram desfechar o golpe de Estado de 10 de novembro. A proibição das delegações legislativas, consagrada na Constituição de 1934, não impediu que se encontrassem os caminhos adequados ao livre trânsito da idéias autoritárias." ${ }^{301}$

De todo modo, segundo Bandeira de Mello, nas delegações legislativas disfarçadas a lei estaria se sobrepondo à $\mathrm{CRFB} / 88$, o que seria "juridicamente inadmissível em regime de Constituição rígida.",302

Especificamente no âmbito da regulação do mercado de capitais, a discussão gira em torno da juridicidade das Instruções emanadas pela CVM - que são os atos administrativos normativos adotados pela autarquia para

\footnotetext{
${ }^{301}$ LEAL, Victor Nunes. Op. cit. p. 95.

${ }^{302}$ MELLO, Celso Antonio Bandeira de. Op. cit. p. 356.
} 
veicular seu poder regulador. ${ }^{303}$ Deve-se lembrar que, para Nelson Eizirik, o conteúdo da Deliberação n. 01/78 deixa claro que as Instruções são

"os únicos atos de natureza normativa, mediante os quais a CVM, nos termos do disposto no inciso I do art. $8^{\circ}$ da Lei $n^{\circ}$ 6.385/76, regulamenta as matérias expressamente previstas na Lei das SA e na Lei $n^{\circ}$ 6.385/76." ${ }^{304}$

O autor defende que as Instruções da CVM são dotadas de eficácia e coercibilidade, são fontes do Direito e podem vir a fundamentar decisões administrativas e judiciais. ${ }^{305}$

Trazendo o entendimento da corrente tradicional de direito administrativo ao caso do mercado de capitais, conclui-se que, segundo ela, as Instruções da CVM padeceriam de inconstitucionalidade justamente por inovar na esfera jurídica (ou seja, constituir fonte primária de direito). Segundo Bandeira de Mello, inovar significa introduzir algo cuja preexistência não se pode conclusivamente deduzir da lei regulamentada. ${ }^{306}$

Deve-se aqui fazer um breve aparte para trazer à tona entendimento diverso e relevante para a análise. Segundo Victor Nunes Leal, com base

\footnotetext{
${ }^{303}$ LUCENA, José Waldecy. Op. cit. p. 145. Com efeito, consta do primeiro item da Deliberação n. $01 / 78$ : "INSTRUÇÃO

Para consubstanciar os atos através dos quais a CVM, nos termos do disposto no inciso I do Art. $8^{\circ}$ da LEI No 6.385, de 07-12-1976 (Lei que dispõe sobre o Mercado de valores Mobiliários e cria a CVM) regulamentará as matérias expressamente previstas naquela Lei e na LEI $N^{o} 6.404$, de 15-12-76 (Lei das Sociedades por Ações)."

${ }^{304}$ EIZIRIK, Nelson. Reforma das S.A. e do Mercado de Capitais. p. 154.

${ }^{305}$ Id., ibid. p. 154.

${ }^{306}$ MELLO, Celso Antonio Bandeira de. Op. cit. p. 359. O Autor gostaria de observar que a adoção da definição do vocábulo "inovar" dada por Bandeira de Mello, embora bastante condizente com seu uso corrente, tem como consequência abarcar enorme gama de atos normativos emanados por agências reguladoras, bem como inúmeros decretos presidenciais senão todos. Também abarcaria vários - senão todos os - dispositivos dos regimentos dos Tribunais do País. O Autor não pretende fazer, neste momento, juízo de valor sobre esta implicação. Ela será feita em momento posterior. O caráter não inovador dos regulamentos emanados por agências reguladoras parece ter encontrado apoio na doutrina mais recente. A respeito, cf. CALIL, Lais. O Poder Normativo das Agências Reguladoras em face dos Princípios da Legalidade e da Separação de Poderes. In: BINENBOJM, Gustavo (coord.). Agências Reguladoras e Democracia. Rio de Janeiro: Lumen Juris, 2006. pp. 111-176. A autora, contudo, dá a entender que este requisito estaria suprido pela previsão do poder normativo pela lei instituidora da agência. Neste aspecto, não diferiria muito de algumas das teses mais modernas, expostas abaixo.
} 
em Leon Duguit, a diferença entre o regulamento e a lei não é substancial, de natureza, e sim formal, de grau, de hierarquia. Ambos têm natureza normativa. $\mathrm{O}$ que distingue o regulamento da lei é que o primeiro não pode contrariar o segundo.

\section{A consequência é que}

“[...] se o regulamento completa a lei, (e sem êsse papel seria êle perfeitamente desnecessário), é evidente que a lei sempre deixa alguma coisa para o regulamento. Em outras palavras, tôda lei passível de regulamentação contém em si mesma certa margem, por pequena que seja, de delegação ao poder executivo, ao qual compete expedir os regulamentos." 307

Partindo-se, então, do pressuposto que há, de qualquer forma, um espaço deixado para o regulamento, e que há necessariamente uma delegação, a teoria tradicionalista se veria obrigada a solucionar uma contradição. Na palavras de Nunes Leal,

"[e]is aí o primeiro problema jurídico que surge da orientação que prevaleceu na Constituição de 1934 e que também predomina na Assembléia Constituinte de 1946 [a de vedar as delegações normativas]. Seria impossivel estabelecer a priori um critério capaz de solucionar as dúvidas. $O$ regulamento, dado o seu papel de texto complementar da lei, envolve sempre a ideia de lacuna legislativa, o que equivale a dizer que contém sempre algum resíduo legislativo, uma certa medida de autoridade delegada. Por isso mesmo, não deixa de haver uma certa dose de contradição, por pequena que seja, entre proibir as delegações legislativas e conservar nas mãos do executivo a faculdade regulamentar." ${ }^{308}$

De todo modo, a corrente dita tradicionalista não deixa de ter adeptos e de ter força argumentativa. ${ }^{309}$

\subsubsection{Teses favoráveis}

O Autor aqui aglutinou as teses mais difundidas que se manifestaram favoravelmente ao poder normativo da CVM. Embora se toquem e se complementem em determinados aspectos, elas não dividem muitas

\footnotetext{
${ }^{307}$ LEAL, Victor Nunes. Op. cit. pp. 99-100.

${ }^{308}$ Id., ibid. p. 102.

${ }^{309}$ Cf. FIGUEIREDO, Lucia Valle. Curso de Direito Administrativo. $5^{\mathrm{a}}$ ed. revista, atualizada e ampliada. São Paulo: Malheiros, 2001. pp. 134-142.
} 
características em comum e podem ser contraditórias entre si. Por esta razão, serão examinadas individualmente.

\subsubsection{A delegação permitida}

É absolutamente essencial comentar, logo no início, o estudo Mercado de Capitais e "Insider Trading”, de Luís Gastão Paes de Barros Leães, publicado em 1978 como tese de concurso. Trata-se de um dos primeiros textos - senão o primeiro - que se pronunciou sobre o poder normativo da CVM após a promulgação da Lei n. 6.385/76 e que adquiriu grande relevância no cenário jurídico nacional.

Antes de mergulhar na discussão sobre as regras de vedação ao insider trading nos EUA e no Brasil, Leães faz primeiro um excurso às circunstâncias políticas e às doutrinas jurídicas que fundamentam a regulação do mercado de capitais e a atividade de polícia desempenhada pelo Estado - por meio da CVM.

Observa o autor que, sob o regime da Constituição de 1969, seria permitida a delegação legislativa ao Presidente da República, por mais que se opusesse uma parte considerável da doutrina tradicional (dentre os quais, Oswaldo Aranha Bandeira de Mello e Geraldo Ataliba). ${ }^{310} \mathrm{O}$ autor se posiciona favoravelmente a esta novidade da Constituição de 1969 em relação às Constituições de 1934 e 1946:

"A impugnação não parece procedente, tanto mais que se baseia em interpretação acanhada da norma constitucional que atribui ao Executivo competência para execução da ordem legislativa. Como saliente Bielsa, nada mais legítimo que nos setores não ocupados pela legislação, mas nos quais não haja proibição constitucional, o Poder Executivo aja no cumprimento de sua competência, que é genérica, de dar execução à ordem legislativa, expedindo regulamentos, já que a Constituição não se limita a lhe deferir competência

${ }^{310}$ LEÃES, Luís Gastão Paes de Barros. Mercado de Capitais e "Insider Trading”. São Paulo: Revista dos Tribunais, 1982. p. 39. 
específica de dar execução a certa e determinada lei anterior. Nessa esfera de ação, a autoridade administrativa exerce o seu poder discricionário."311

Vigoraria, pelo menos no regime instaurado pela Constituição de 1969, sob a qual se promulgou a Lei n. 6.385/76, uma interpenetração, ou imbricação, entre os Poderes do Estado, uma vez evidenciada, tanto pela doutrina quanto pela nova ordem constitucional, que " $a$ independência $e$ harmonia dos Poderes não devem induzir a que se trate de compartimentos estanques.",312

Ao argumento vai além: a delegação da competência administrativa pelo chefe do Executivo (o Presidente da República) permitiria que o poder regulamentar se expressasse em regulamentos não necessariamente de competência exclusiva do Presidente, mas, antes, emanados por outros órgãos da administração:

"A capacidade ordenatória do Estado se manifesta por meio de círculos concêntricos que vão, sucessivamente, da Constituição à lei material e formal, isto é, àquela elaborada pelos órgãos legislativos; desce aos regulamentos por meio dos quais o Presidente da República complementa e particulariza as leis; $e$, finalmente, aos atos administrativos gerais, originários das várias escalas de competência administrativa. São constantes as normas, de força obrigatória equivalente às leis e regulamentos, desde que a elas ajustadas, contidas em portarias, ordens de serviço, circulares, instruções ou meros despachos. É, em suma, a substância, e não a forma, que exprime a distinção entre o ato administrativo especial (decisão específica) e o ato administrativo geral (ato normativo). Aquele, tal como as decisões judiciais, aplica o direito ao caso, solvendo uma postulação concreta. Este representa a formação de uma ordem nova, complementar ao direito existente, que esclarece e desenvolve, tendo, obviamente, conteúdo inovador, embora mínimo." 313

A delegação exercida pela lei ao órgão da administração indireta, como o CMN, o BACEN e a CVM, portanto, está amparada no fato de que é constitucional a delegação administrativa. ${ }^{314}$

\footnotetext{
${ }^{311}$ Id., ibid. pp. 39-40.

${ }^{312}$ Id., ibid. p. 41.

313 TÁCITO, Caio. O Mandado de Segurança e o Poder Normativo da Administração, apud LEÃES, Luís Gastão Paes de Barros. Op. cit. p. 43.

${ }^{314}$ LEÃES, Luís Gastão Paes de Barros. Op. cit. p. 44.
} 
Deve-se também analisar o artigo O Poder Normativo de Órgãos da Administração: o caso da Comissão de Valores Mobiliários, de Bolívar B. M. Rocha, publicado ainda em 1986. Trata-se provavelmente de um dos primeiros textos na literatura brasileira que procura justificar o poder normativo da CVM. Ao invés de partir da moderna distinção entre regulação e regulamentação, o autor sustenta tratar-se de fato de exercício de delegação legislativa ao Executivo, apresentando argumentos pelos quais entende que, no caso da CVM, tal exercício seria constitucional. ${ }^{315} \mathrm{O}$ argumento do autor é ainda mais interessante do ponto de visto histórico porque comenta as sugestões de Fábio Konder Comparato formuladas à Assembleia Constituinte que estaria na iminência de se constituir a fim de se sanar a controvérsia de uma vez por todas.

Bolívar Rocha acaba concluindo pela "inevitabilidade do exercício de uma parcela de poder legislativo pelo Executivo." 316 O poder de polícia pressupõe uma parcela de competência normativa, especialmente nos casos em que há certa discricionariedade administrativa conferida ao órgão pela lei. ${ }^{317}$ No caso específico das agências reguladoras, tal parcela de poder normativo seria necessária à consecução dos propósitos para os quais foram criadas e imanente a elas. ${ }^{318}$

Isto não seria novidade alguma, especialmente nos EUA. ${ }^{319}$ Naquele país os autores não confeririam caráter tão absoluto ao princípio da separação de poderes. Haveria, ao invés disso, uma mescla de funções entre

\footnotetext{
${ }^{315}$ Cf. ROCHA, Bolívar B. M. O Poder Normativo de Órgãos da Administração: o caso da Comissão de Valores Mobiliários. Revista de Direito Mercantil, Industrial, Econômico e Financeiro, ano XXV, n. 64, out. - dez. 1986. pp. 47-69.

${ }^{316}$ Id., ibid. p. 58.

${ }^{317}$ Id., ibid. p. 59.

${ }^{318}$ Id., ibid. p. 60.

${ }^{319}$ Tampouco no Brasil. Basta lembrar da SUMOC, criada pelo Decreto-Lei n. 7.293/45, e do BACEN, criado pela Lei n. 4.595/64.
} 
os poderes, a fim de que o Legislativo pudesse realizar plenamente suas atividades. $^{320}$

Tampouco o princípio delegatus non potest delegare deveria ser interpretado de forma tão restritiva e absoluta. Se ao Poder Legislativo cabe atribuir e delegar deveres, ele também pode delegar a outros Poderes competência para desempenhar atos que ele não possa - ou mesmo que ele possa - executar. ${ }^{321}$

Bolívar Rocha, citando John Cheadle, afirma que a adoção de planos de ação, ou as políticas de forma mais genérica, caberiam ao Legislativo; enquanto os meios para se levar a cabo seu cumprimento poderiam ser levados a cabo por outro Poder, de forma delegado. Cheadle afirmaria que, na realidade, tal delegação constitui um dever do Legislativo sempre que ele entende que outra pessoa ou órgão podem executar a função de forma mais eficiente. A conclusão é que o bom funcionamento do sistema permite - e exige - que o Legislativo delegue função normativa ao Executivo, uma vez existente boa justificação e conveniência. ${ }^{322}$

A delegação, segundo Vergottini, seria justificada pela superação da noção de separação entre governo e parlamento - e sua substituição pela noção de simbiose entre os dois. Desta forma, a ideia de que o Poder Legislativo controla o Poder Executivo perde seu sentido, e ganha força a ideia de que os partidos de minoria, que são representados no parlamento mas não tem participação no governo, é que controlam os partidos de maioria (estes sim presentes tanto no parlamento quanto no governo). ${ }^{323} \mathrm{~A}$ conveniência da delegação residiria na natureza técnica e complexa da

\footnotetext{
${ }^{320}$ Id., ibid. p. 48.

${ }^{321}$ Id., ibid. p. 49.

${ }^{322}$ CHEADLE, John. Delegation of Legislative Functions, apud ROCHA, Bolívar B. M. Op. cit. p. 49.

${ }^{323}$ VERGOTTINI, Giuseppe de. Direito Constitucional Comparado, apud ROCHA, Bolívar B. M. Op. cit. pp. 50-51.
} 
matéria regulada, bem como na necessidade de uma atuação urgente, com elevado grau de executoriedade. ${ }^{324}$

Prossegue o autor enumerando os limites a esta possibilidade de delegação: (i) o Legislativo não pode delegar o poder de legislar propriamente dito; (ii) o Legislativo não pode delegar a competência para fazer planos genéricos, somente permitindo que o Executivo escolha o melhor meio para executar tais planos; (iii) o Legislativo, ao delegar, deve fazer constar da lei “o objeto, os fins, as diretrizes, as condições e os limites em que se exercerá a atribuição delegada.",325

Cabe, por fim, ressaltar que Bolívar Rocha reconheceu que o poder normativo de que trata em seu artigo não se confunde com o poder regulamentar do Presidente da República, previsto no art. 81, III, da CRFB/67 (atual art. 84, IV da CRFB/88). ${ }^{326}$ Esta ideia acabaria assumindo a posição central na tese de Eros Roberto Grau, que será exposto adiante.

\subsubsection{A discricionariedade técnica}

A discricionariedade técnica também foi um dos primeiros fundamentos do poder normativo das agências reguladoras. Maria Sylvia Zanella Di Pietro afirma que tanto a noção de discricionariedade técnica quanto a de agência reguladora penetraram no direito brasileiro por influência do direito norte americano. ${ }^{327}$

\footnotetext{
${ }^{324}$ ROCHA, Bolívar B. M. Op. cit. pp. 51-52.

${ }^{325}$ Id., ibid. pp. 54-55.

326 “A objeção, portanto, não pode ser à delegação, pelo Legislativo, de funções normativas. Esta seria permitida, e sobretudo exigida, pelo sistema, como imperativo de bom funcionamento. A objeção passa a ser, isto sim, à abdicação do próprio poder de legislar; à delegação ao Executivo de poderes exclusivamente legislativos, à subdelegação do Poder Legislativo propriamente dito." Id., ibid. p. 50.

327 PIETRO, Maria Sylvia Zanella di. Discricionariedade Técnica e Discricionariedade Administrativa. Revista Eletrônica de Direito Administrativo Econômico, n. 9, fev. - abr. 2007. Salvador, Instituto Brasileiro de Direito Público. Disponível em < http://www.direitodoestado.com/revista/REDAE-9-FEVEREIRO-2007-
} 
Segundo a autora, a expressão foi primeiro utilizada em 1864 por Edmund Bernatzik, da Escola de Viena. ${ }^{328}$ Tratar-se-ia de um poder de decisão próprio do administrador porque somente este, por sua formação técnica, entenderia das questões postas a ele. Tais decisões, por esse motivo, não estariam sujeitas ao controle judicial. ${ }^{329}$

Relata a autora que a noção de discricionariedade técnica subsistiu em alguns países; em outros, se misturou à noção de conceito jurídico indeterminado. De qualquer forma, a noção de que não caberia ao Poder Judiciário a apreciação do mérito dos atos administrativos, posto que haveria alguma forma de discricionariedade, acabou sendo abandonada na maioria dos países. Ao Judiciário caberia encontrar, dentro das escolhas permitidas pela lei, a melhor solução. ${ }^{330}$

$\mathrm{Na}$ Itália, relata Maria Sylvia di Pietro que o conceito foi desenvolvido por Renato Alessi. Em definição absolutamente simples, temse a discricionariedade técnica quando a apreciação do interesse público depende de critérios técnicos e "a solução de questões técnicas que devem realizar-se conforme as regras e os conhecimentos técnicos". 331

Há hipóteses em que a lei permitiria ao administrador verdadeira discricionariedade frente a critérios técnicos, pois ele, a despeito da existência destes, poderá apreciar o interesse público inerente à decisão. Em outros casos, contudo, o administrador não poderá fazê-lo, devendo seguir o comando dado pela lei em face de um determinado critério técnico. O exemplo dado pela autora é ilustrativo: quando a lei manda a destruição de mercadorias deterioradas, não pode a administração deixar de fazê-lo - ante

MARIA\%20SYLVIA.pdf>. Acesso em 11 nov. 2013. p. 1. PIETRO, Maria Sylvia Zanella di. Op. cit. p. 1 .

${ }^{328}$ Id., ibid. p. 4.

${ }^{329}$ SOUSA, António Francisco de. "Conceitos Indeterminados" no Direito Administrativo, apud PIETRO, Maria Sylvia Zanella di. Op. cit. p. 4.

${ }^{330}$ Id., ibid. pp. 4-5.

${ }^{331}$ Id., ibid. p. 5. 
a verificação pelo órgão técnico de que as mercadorias estão deterioradas, deve destruí-las. ${ }^{332}$

Exatamente por este motivo alguns autores sustentam que a discricionariedade técnica não é, na realidade, uma discricionariedade, pois não permite a decisão segundo critérios de conveniência e oportunidade. Isto teria levado alguns autores a chamá-la de "discricionariedade imprópria". 333

No direito europeu, a tese da discricionariedade técnica acabou sendo utilizada como baliza para o controle pelo Judiciário de atos do Executivo. Foi no direito norte americano que esta ideia se prestou a justificar o poder normativo das agências reguladoras. ${ }^{334}$

Cabe aqui recordar a noção de que a discricionariedade inerente à delegação de poderes importa necessariamente um poder normativo para o órgão da administração que recebeu tal delegação, noção esta que foi inicialmente exposta acima, em comentário ao artigo de Bolívar Rocha.

Caberia, segundo Maria Sylvia di Pietro, às agências reguladoras baixar atos normativos que se conformassem aos standards contidos na lei e na Constituição. ${ }^{335} \mathrm{~A}$ autora aponta, ainda, três ideias que constituíram os pilares do modelo das agências reguladoras norte americanas: (i) especialização; (ii) neutralidade; e (iii) descentralização técnica. ${ }^{336}$

Por especialização se entende que o Estado atua de forma mais eficiente nos vários campos econômicos e sociais a que se propõe atuar caso o faça por intermédio de entes especializados em determinadas

\footnotetext{
${ }^{332}$ Id., ibid. p. 6.

${ }^{333}$ Id., ibid. p. 1.

${ }^{334}$ Id., ibid. p. 8 .

335 Id., ibid. p. 8.

${ }^{336}$ Id., ibid. p. 9.
} 
matérias. A descentralização técnica é decorrente desta noção, uma vez que leva à ampliação da administração indireta com base em critérios técnicos. Por neutralidade se entende que a agência reguladora estaria isenta de influências políticas e do Presidente da República, uma vez que dotada de estabilidade nas suas funções. ${ }^{337}$

Cabe uma breve excursão ao elemento da especialização, uma vez que é ele que guarda relação com a discricionariedade técnica e que fundamenta o poder normativo das agências reguladoras.

Di Pietro relata que no direito norte americano logo foi conferido às agências reguladoras elevado grau de discricionariedade - isto é, o mérito de seus atos estava fora do controle judicial, por envolver conhecimento técnico, a não ser que se tratasse de ato manifestamente arbitrário, absurdo ou caprichoso.

Este amplo grau de discricionariedade não teria durado muito tempo. Logo os princípios da motivação, da racionalidade e da razoabilidade dos atos normativos, bem como o da proporcionalidade, seriam aplicados aos atos das agências reguladoras norte americanas, tanto nos casos de atos normativos quanto nos de atos adjudicatórios. ${ }^{338}$

Concluindo tendo em vista o direito brasileiro, a autora entende que a questão da discricionariedade técnica enquanto motivadora do poder normativo das agências reguladoras deve ser vista com base no poder regulamentar do Presidente da República (art. 84, IV, CRFB/88) e dos Ministérios (art. 87, II, da CRFB/88). A matéria também se encontraria

\footnotetext{
${ }^{337}$ Id., ibid. p. 9.

${ }^{338}$ Id., ibid. p. 10.
} 
regulada pelo art. 25 do ADCT, que revogou todos os atos de delegação normativa a órgão do Poder Executivo. ${ }^{339}$

O único modo que a autora concebe para justificar a constitucionalidade do poder normativo atribuído às agências reguladoras é a redução do conceito de regulamento,

"[...] para dele excluir as normas que apenas definem conceitos técnicos contidos na lei. E isto pelo fato de que a discricionariedade técnica não constitui verdadeira discricionariedade, não envolve decisão política, porque não dá liberdade de escolha para a Administração. O órgão regulador limita-se a definir um conceito que já está contido na lei e cujo conteúdo vai ser apenas explicitado na norma infra legal.",340

Como consequência, se um órgão regulador baixa atos normativos definindo conceitos indeterminados, especialmente técnicos e de experiência, não significa que exerce poder regulamentar. $\mathrm{O}$ poder regulamentar, como desenvolvido pela autora no trecho transcrito, está associado à competência discricionária propriamente dita, não tendo nada a ver com a competência discricionária técnica (que nem discricionária é, posto que nela somente há uma solução possível). ${ }^{341}$

Contudo, segundo esta tese, trata-se de meramente tornar explícito aquilo que a lei quer dizer quando emprega um conceito jurídico indeterminado. As agências reguladoras não estariam com isso autorizadas a inovar no ordenamento jurídico. ${ }^{342}$

Embora Maria Sylvia Di Pietro não trate da matéria, o Autor entende que, no caso específico do mercado de capitais, a aplicação desta tese resultaria na mera definição, pela CVM, de conceitos indeterminados contidos na LSA e na Lei n. 6.385/76 com base em conhecimentos

\footnotetext{
${ }^{339}$ Id., ibid. p. 3.

${ }^{340}$ Id., ibid. p. 8.

${ }^{341}$ Id., ibid. p. 13.

${ }^{342}$ Id., ibid. p. 17.
} 
econômicos. Não é isto que ocorre. A CVM tem, com o respaldo conferido por certos dispositivos da Lei n. 6.385/76 e da LSA, efetivamente inovado no ordenamento jurídico, não se limitando a esclarecer, mediante o emprego de conhecimento das ciências econômicas, os conceitos contidos na legislação societária.

Por este motivo, a tese da discricionariedade técnica proposta por Maria Sylvia Zanella di Pietro somente justifica parte da atividade normativa da CVM. Este Autor entende que, em comparação com as demais teses aqui analisadas, ela seja uma tese moderada do poder normativo das agências reguladoras.

\subsubsection{Agências reguladoras como um Poder "à parte"}

A doutrina moderna é caracterizada, de forma resumida, pelo reconhecimento não de uma delegação de poderes do Legislativo ao Executivo, mas de uma atuação independente das agências reguladoras em determinados casos quasi-judicante, em outros quasi-legislativa - no domínio econômico devido às novas realidades. As agências reguladoras são tratadas como independentes dos demais Poderes. ${ }^{343}$ Sua função exercida, a regulação, não é a mesma coisa que regulamentação, disposta no já mencionado art. 84 , inciso IV, da CRFB/88. ${ }^{344}$

No entender de Eizirik et alii,

"[a] regulamentação é atribuída a chefes de Estado ou Governo e é uma função política, que visa a impor regras de caráter secundário em complementação às normas legais, com o objetivo de explicitá-las e dar-lhes execução. Já a regulação constitui uma função administrativa, que não decorre da prerrogativa do poder político, e sim da "abertura" da lei para que o agente regulador

\footnotetext{
${ }^{343}$ EIZIRIK, Nelson et al. Mercado de Capitais: regime jurídico. ppp. 268-269.

${ }^{344}$ A noção de função é assim definida por Eros Roberto Grau: "[...] a extensão do poder estatal, enquanto preordenado às finalidades de interesses coletivo e objeto de um dever jurídico tomada a expressão poder estatal, então, no seu aspecto material." GRAU, Eros Roberto. O Direito Posto e o Direito Pressuposto. $7^{\mathrm{a}}$ ed. revista e ampliada. São Paulo: Malheiros, 2008. p. 237.
} 
pondere, de forma neutra, conflitos entre os interesses público e privado, sejam eles potenciais ou efetivos." ${ }^{345}$

Diogo de Figueiredo Moreira Neto fez distinção entre regulamentação e regulação que se tornou conhecida:

\begin{abstract}
"De um lado, sob o aspecto material, a regulamentação é uma função política, desempenhada no exercício de uma prerrogativa do poder político de impor regras secundárias, em complemento das normas legais, como objetivo de explicitá-las e de dar-lhes execução, sem que possam definir quaisquer interesses públicos específicos nem, tampouco, criar, modificar ou extinguir direitos subjetivos.

[...]

De outro lado, substantivamente, a regulação, até mesmo por suas características enunciadas, é uma função administrativa, que não decorre, portanto, de uma prerrogativa do poder político, mas, muito pelo contrário, deriva da abertura, pela lei, de um espaço decisório deslegalizado, reservado à ponderação política neutra de interesses concorrentes, em conflitos setoriais, potenciais ou efetivos." 346
\end{abstract}

Esta tese pode ser vista como um desdobramento da tese de Bolívar Rocha acima exposta. Contudo, leva o argumento a extremos, pois considera que as agências reguladoras constituiriam um Poder do Estado à parte. A tese parece repousar sobre (i) a possibilidade de deslegalização, e (ii) sobre a noção de que as agências reguladoras constituem um poder autônomo frente a outros. A ideia não é de todo isenta a críticas, uma vez que a CRFB/88 (i) é expressa quanto à adoção da tripartição dos poderes, e (ii) vedaria, ainda que implicitamente, a existência de regulamentos delegados ou autônomos. ${ }^{347}$

\title{
4.3.2.4. Poder normativo e delegação
}

Segundo esta corrente, capitaneada entre nós por Eros Roberto Grau, o exercício da função reguladora repousaria, dentre outros, sobre a função

\footnotetext{
${ }^{345}$ EIZIRIK, Nelson et al. Op. cit. p. 270.

${ }^{346}$ MOREIRA NETO, Diogo de Figueiredo. Op. cit. pp. 402-403.

${ }^{347}$ A crítica, embora não estruturada desta forma, é feita por CALIL, Lais. O Poder Normativo das Agências Reguladoras em face dos Princípios da Legalidade e da Separação de Poderes. In: BINENBOJM, Gustavo (coord.), Agências Reguladoras e Democracia. Rio de Janeiro: Lumen Juris, 2006. pp. 148-149.
} 
normativa. Esta, por sua vez, não deveria ser confundida com a função legislativa. ${ }^{348}$

Apoiando-se sobre a doutrina de Renato Alessi, este autor afirma que a taxonomia das funções legislativa, executiva e judiciária foi construída a partir de uma perspectiva subjetiva (ou orgânica ou institucional), decorrente de uma estrutura de separação dos poderes. ${ }^{349}$ Sob esta perspectiva, as funções corresponderiam aos poderes do Estado - por isso comumente se diz que uma função pode ser exercida típica ou atipicamente por um poder.

Contudo, o autor propõe o abandono da perspectiva orgânica e a adoção de uma perspectiva material das funções do Estado. Sob esta perspectiva a nova taxonomia de suas funções conteria as funções normativa, administrativa e jurisdicional. ${ }^{350}$

A função normativa seria, portanto, a de "emanar estatuições primárias - seja em decorrência do exercício de poder originário para tanto, seja em decorrência de poder derivado - contendo preceitos abstratos e genéricos." ${ }^{351}$ Nesta definição alguns conceitos precisam ser precisados.

Em primeiro lugar, o caráter primário das estatuições - ou primariedade - refere-se ao caráter inovador do texto, ou seja, de sustentarse, impor-se, por força própria. ${ }^{352}$ Em segundo lugar, a noção de originariedade refere-se à atribuição de um órgão de estatuir aquela determinada norma. ${ }^{353}$

\footnotetext{
${ }^{348}$ Deve-se retomar aqui a já explicada noção de função.

${ }^{349}$ GRAU, Eros Roberto. Op. cit. p. 237.

${ }^{350}$ Id., ibid. p. 238.

${ }^{351}$ Id., ibid. p. 240.

${ }^{352}$ Id., ibid. p. 239.

${ }^{353}$ Id., ibid. p. 240.
} 
Grau explica que Alessi diferencia a originariedade da primariedade. Em outras palavras, é perfeitamente possível, para Alessi, uma norma primária - inovadora - emanada por um órgão que não tenha a atribuição originária para emaná-la. Ele pode ser dotado de tal atribuição de forma derivada. ${ }^{354}$

Tal diferenciação explicaria a diferença entre função legislativa e função normativa. Enquanto a primeira seria de legiferar - fazer leis - a segunda seria de fazer normas. A conclusão seria que nem sempre as duas funções seriam exercidas no mesmo ato. A título de exemplo, tome-se o Congresso Nacional. Este pode promulgar tanto leis em sentido lato - que, neste caso, criariam, alterariam ou extinguiriam direitos individuais quanto leis em sentido estrito - estas sim dotadas de generalidade e abstração. ${ }^{355}$

No ordenamento jurídico brasileiro, portanto, a função normativa não caberia exclusivamente ao Poder Legislativo, e sim a todos os Poderes, que a exercem de uma forma ou outra. No âmbito do Poder Executivo, o regulamento representa perfeitamente um caso de função normativa primária - que inova no ordenamento jurídico - mas não é originária dele, e sim derivada. ${ }^{356}$

Para que o órgão possua a função normativa de forma derivada, seria necessário, óbvio "uma atribuição de poder normativo contida explícita ou implicitamente na Constituição ou em uma lei formal." ${ }^{357}$ Não se trataria de delegação de função legislativa - esta sim indelegável - mas de atribuição de função normativa - esta delegável, posto que não privativa do Poder

\footnotetext{
${ }^{354}$ Id., ibid. p. 240.

${ }^{355}$ Id., ibid. pp. 241-242.

${ }^{356}$ Id., ibid. p. 243

${ }^{357}$ Id., ibid. p. 243.
} 
Legislativo. Não haveria, portanto, derrogação (ou violação) ao princípio da indelegabilidade dos poderes. ${ }^{358}$

Por fazer uma diferenciação entre função legislativa e função normativa que possibilita a órgãos não integrantes do Poder Legislativo emanar normas de caráter primário, inovador, esta tese de Eros Grau parece ser a mais arrojada encontrada pelo Autor.

\subsubsection{Conclusão parcial in abstrato: a posição do Autor}

Ao todo, este trabalho examinou cinco teses distintas, cada uma com sua peculiaridade. ${ }^{359}$ Três delas justificam o poder normativo exercido pela CVM; uma somente o justifica parcialmente; ainda outra o reputa escandalosamente inconstitucional.

Como advertido no início deste subcapítulo, a discussão é eminentemente acadêmica. Com efeito, a atuação da CVM enquanto órgão regulador do mercado de capitais já se encontra em estágio virtualmente irreversível. A ela se acomodaram todos os agentes do mercado, que participam da elaboração de seus atos normativos; e que respeitam suas normas e decisões em casos concretos na quase totalidade dos casos.

Neste sentido, a tese acadêmica escolhida por este Autor para prosseguir com este estudo tem pouca importância prática, a não ser para argumentar acerca dos limites da atuação da CVM. Esta questão sim tem relevância prática e pode ser levada a tribunais brasileiros para que estes ampliem ou reduzam, de forma marginal, o poder normativo da autarquia.

\footnotetext{
${ }^{358}$ Há, portanto, uma diferença entre reserva de lei e reserva de norma. Eros Grau conclui seu raciocínio afirmando que a função normativa (do critério material) compreende as funções legislativa, regulamentar e regimental (do critério orgânico, pertencentes aos Poderes Legislativo, Executivo e Judiciário, respectivamente). Id., ibid. pp. 243-244.

${ }^{359}$ Cf. CALIL, Laís. Op. cit. pode-se encontrar tentativa de sistematização diferente das várias teses sobre o assunto.
} 
Qualquer discussão acerca do poder normativo em sua integralidade, contudo, é inócua - ele existe e é irreversível.

Em que pese a força da corrente contrária ao poder normativo da CVM, este Autor se filia a correntes mais favoráveis - notadamente a capitaneada por Eros Roberto Grau. O Autor entende que ela dá conta de forma mais completa do fenômeno de formação do direito ao dissociar a função legislativa da normativa. Claramente órgãos não vinculados ao Poder Legislativo têm, sob a CRFB/88, o poder de emanar normas primárias, que inovam no ordenamento jurídico. Uma observação mais atenta revela que mesmo os decretos regulamentares emanados pelo Presidente da República inovam, e sempre inovaram, consistentemente, no ordenamento jurídico. ${ }^{360}$ Mesmo os decretos regulamentares que procuram definir o conceito de uma expressão empregada na lei, esmiuçando-lhe nos detalhes, alteram seu conteúdo semântico, seja para aumentá-lo ou restringilo, e portanto o direito. Por fim, a tese de Eros Roberto Grau ainda oferece a vantagem de dar conta da validade dos regimentos internos dos tribunais.

À luz desta teoria, é perfeitamente válido em nosso ordenamento o item 13.11 do Anexo 24 da ICVM 480, que determina a divulgação, no Formulário de Referência, das remunerações individuais máxima, mínima e média da diretoria e dos conselhos de administração e fiscal. Mais abstratamente, é perfeitamente válida, de forma geral, outra solução adotada pela CVM em sua atuação reguladora do mercado de capitais.

Evidentemente, há limitações implícitas a tal poder, como o próprio Eros Grau reconhece. Tal limitação é justamente aquela definida na lei, bem como o interesse público que reside na própria atividade normativa do

\footnotetext{
${ }^{360}$ Ainda que minimamente. É o que observa TÁCITO, Caio. O Mandado de Segurança e o Poder Normativo da Administração, apud LEÃES, Luís Gastão Paes de Barros. Op. cit. p. 43.
} 
órgão. ${ }^{361}$ Não poderia a CVM, por exemplo, criar tal obrigação para companhias fechadas. Tampouco poderia criar uma obrigação, ainda que dentro do escopo do mercado de capitais, contrária ao interesse público que motivou esta atribuição de funções. Por fim, não pode a CVM editar ato normativo expressamente contrário à lei.

Para examinar este aspecto, é oportuna uma breve excursão à discussão sendo travada atualmente em nosso Judiciário entre o IBEF e a CVM no que tange ao já mencionado item 13.11 do Anexo 24 da ICVM 480.

\subsubsection{Conclusão parcial in concreto: a ação IBEF v. CVM}

A ação movida pelo IBEF contra a CVM objetiva a declaração da invalidade, para todos os associados do IBEF, do item 13.11 do Anexo 24 da ICVM 480. Os argumentos jurídicos levantados pela parte autora, que se insurge contra o ato normativo, são resumidamente os seguintes: (i) não pode ato de órgão do Poder Executivo inovar no ordenamento jurídico; (ii) contrariedade ao art. 152 da LSA, que permite que a assembleia geral da companhia delibere sobre a remuneração global ou individualmente; (iii) contrariedade ao art. $157, \S 1^{\circ}$, alíneas $c$ e $d$, da LSA, que dispõe de modo taxativo como se deve divulgar a remuneração individualizada dos administradores da companhia; e (iv) violação dos direitos à privacidade, intimidade e segurança dos membros dos órgãos da companhia.

O Autor, já tendo se posicionado a respeito do poder normativo da CVM e demais agências reguladoras, se furtará a examinar abaixo o primeiro argumento. Também se furtará a examinar alegações de violação a direito da privacidade, intimidade e segurança, posto que exorbitam o campo do direito empresarial, bem como a própria análise econômica

${ }^{361}$ EIZIRIK, Nelson et al. Op. cit. p. 250. 
proposta pelo Autor. Passará a examinar os demais abaixo, na ordem em que foram apresentados.

\title{
4.3.4.1. Contrariedade ao art. 152 da LSA
}

Diz o art. 152 da LSA que

\begin{abstract}
"[a] assembléia-geral fixará o montante global ou individual da remuneração dos administradores, inclusive benefícios de qualquer natureza e verbas de representação, tendo em conta suas responsabilidades, o tempo dedicado às suas funções, sua competência e reputação profissional e o valor dos seus serviços no mercado."
\end{abstract}

Marcelo Barbosa, ao comentar este dispositivo, nota que, muito embora a LSA permita ao conselho de administração que eleja a diretoria, deixa a remuneração de ambos reservada à assembleia geral como medida para evitar que os administradores se sirvam dos recursos da companhia em benefício próprio. ${ }^{362}$ A redação é peremptória neste sentido, dispondo que a assembleia geral é competente para deliberar sobre a "remuneração dos administradores, inclusive benefícios de qualquer natureza e verbas de representação". Qualquer verba paga aos administradores depende de aprovação dos acionistas.

Segundo o IBEF, a contrariedade entre este dispositivo e a divulgação da remuneração dos administradores nos termos da ICVM 480 residiria em dois pontos: (i) a ICVM 480 retiraria da assembleia geral a faculdade de deliberar a remuneração dos administradores de forma global; e (ii) a própria presença do acionista na assembleia geral já garantiria que ele ficasse informado sobre a remuneração individual dos administradores, caso queira.

Com todo o respeito àqueles que os sustentam, este Autor ousa divergir de ambos os argumentos.

${ }^{362}$ BARBOSA, Marcelo. Administradores. In: LAMY FILHO, Alfredo. PEDREIRA, José Luiz Bulhões (coord.). Op. cit. p. 1.081. 
Em primeiro lugar, a ICVM 480 não retira da assembleia geral a faculdade de deliberar a remuneração dos administradores de forma global. O que obriga é que sejam divulgadas as quantias máxima, mínima e média percebidas pelo membro de cada órgão da administração e do conselho fiscal. O momento de individualização da remuneração dos administradores pode se dar na própria assembleia que deliberar sobre a remuneração ou posteriormente. Caberá, então, ao órgão que a individualizar reunir-se e decidir como a remuneração será partilhada entre seus membros. Feito isto, devem as quantias máxima, mínima e média ser divulgadas nos termos da ICVM 480.

Em segundo lugar, a presença do acionista em assembleia geral não necessariamente significa que ele lá se informará da remuneração individual dos membros da diretoria e dos conselhos de administração e fiscal. Isto ocorre precisamente porque pode a maioria dos acionistas preferir decidir somente a remuneração global para cada órgão, deixando para seus membros a decisão sobre a partilha.

A ICVM 480 não substitui a tutela da LSA sobre a informação do acionista a respeito da remuneração dos membros da diretoria e dos conselhos de administração e fiscal - ela a complementa.

Cabe ressaltar, além disto, que a ICVM 480 somente se aplica a companhias abertas - ou seja, a companhias autorizadas pela CVM a emitir e ter seus valores mobiliários negociados em mercados regulamentados. Às companhias fechadas aplica-se normalmente a sistemática da LSA.

\subsubsection{Contrariedade ao art. 157 , $\S 1^{\circ}$, alíneas $c$ e $d$, da LSA}

Trata-se de dispositivo da LSA que tutela o acesso à informação pelo acionista detentor de pequena participação no capital social. Tal é a sua redação: 
“Art. 157.

[...]

$\S 1^{\circ} \mathrm{O}$ administrador de companhia aberta é obrigado a revelar à assembléiageral ordinária, a pedido de acionistas que representem $5 \%$ (cinco por cento) ou mais do capital social:

[...]

c) os beneficios ou vantagens, indiretas ou complementares, que tenha recebido ou esteja recebendo da companhia e de sociedades coligadas, controladas ou do mesmo grupo;

d) as condições dos contratos de trabalho que tenham sido firmados pela companhia com os diretores e empregados de alto nível; [...]"

O IBEF alega, em síntese, que a LSA, ao criar o direito - e regulá-lo minuciosamente - de o acionista detentor de $5 \%$ ou mais do capital ter acesso a informações que incluem a remuneração dos administradores, teria exaurido, com este mecanismo, a disciplina de divulgação da remuneração dos administradores. O item 13.11 do Anexo 24 da ICVM 480, ao criar obrigação relativa a esta matéria, estaria conflitando com a disciplina da LSA sobre o direito a informação do acionista em companhias abertas.

Com todo o acato e consideração pelos juristas que defendem esta tese, o Autor ousa discordar. Para expor seus motivos, fará várias considerações pontuais a respeito do art. $157, \S 1^{\circ}$, da LSA.

A primeira observação a se extrair do $\S 1^{\circ}$ do art. 157 é que ele somente se aplica a administradores de companhias abertas. Por óbvio, ficam desobrigados de cumprir com a obrigação dele constante os administradores de companhias fechadas, bem como os membros do conselho fiscal da qualquer companhia. Logo, de início já se pode perceber que a informação tratada pelo item 13.11 do Anexo 24 da ICVM 480 refere-se a pessoas diferentes daquela tratada pelo art. $157, \S 1^{\circ}$, da LSA.

Além disso, o próprio teor da informação é diferente. No Formulário de Referência (ICVM 480) exige-se a divulgação dos valores das remunerações máxima, mínima e média dentro da diretoria e dos conselhos de administração e fiscal. No art. $157, \S 1^{\circ}$, da LSA o acionista pode ter acesso a informações muito mais detalhadas sobre os incentivos e 
desincentivos econômico-financeiros dos administradores em relação à performance da companhia - basta notar a redação das alíneas $c$ e $d$.

Os destinatários da obrigação também não são os mesmos. Enquanto o art. 157, $\S 1^{\circ}$, da LSA, obriga o administrador a revelar determinadas informações, a ICVM 480 obriga, antes, a própria companhia a fazê-lo. No primeiro caso, a responsabilidade por eventuais danos causados pelo administrador que, licitamente instado a fornecer informações, não as fornece, é do próprio administrador. No segundo caso, a ICVM 480 responsabiliza o diretor de relações com investidores, figura criada pelo art. 44 dessa mesma Instrução, sem prejuízo da responsabilidade dos administradores e controladores da companhia (arts. 42, 43 e 46 da ICVM 480).

Também a responsabilidade é distinta em cada caso. Em um trata-se de responsabilidade civil, circunscrita aos danos causados, por parte do administrador que nega pedido de fornecimento de informações formulado licitamente. ${ }^{363}$ No outro, trata-se de responsabilidade administrativa perante a CVM.

Por fim, são diferentes os titulares do direito. No caso do art. 157, $\S 1^{\circ}$, o direito de requisitar e ter acesso à informação é, muito claramente, do acionista detentor de 5\% ou mais do capital social. Por outro lado, o titular do direito contido no item 13.11 do Anexo 24 da ICVM 480 é o próprio mercado.

Estas observações deixam claro que trata-se informações distintas, destinadas a atender a grupos de pessoas distintos, e, portanto, sujeitas a regimes distintos. Somente um acionista detentor de 5\% ou mais do capital

\footnotetext{
${ }^{363}$ CARVALHOSA, Modesto. Comentários à Lei de Sociedades Anônimas, vol. 3. $5^{\mathrm{a}}$ ed. revista e atualizada. São Paulo: Saraiva, 2011. p. 403.
} 
social pode tomar conhecimento de todas as vantagens e benefícios auferidos por um administrador, ou de seu contrato com a companhia. Contudo, caso queira conhecer as remunerações máxima e mínima dos membros do conselho de administração de uma companhia aberta, por exemplo, não precisa deter tal participação - na realidade, nem precisa ser acionista da companhia.

Bem observa Luiz Antonio de Sampaio Campos que o dever de informação dos administradores de companhias abertas "se desdobra na obrigação de informação aos acionistas e na prestação de informação ao mercado." 364

$\mathrm{O}$ art. 157, $\S 1^{\circ}$, evidencia uma preocupação do legislador com o distanciamento entre o acionista e a companhia aberta e com a informação dos acionistas a respeito de remunerações, benefícios e vantagens percebidos pelos administradores e os executivos de alto nível. ${ }^{365}$

Por outro lado, a regulação exercida pela CVM sobre o mercado de capitais visa a corrigir a assimetria informacional entre os agentes do mercado por meio da divulgação obrigatória de informações ao mercado. Desta forma, acionistas, administradores, controladores e mesmo potenciais investidores partiriam todos de um ponto de partida semelhante, levando-se em conta as informações necessárias para investir ou desinvestir em uma companhia aberta.

O IBEF alega, em síntese, que a LSA, ao criar o direito - e regulá-lo minuciosamente - de o acionista detentor de $5 \%$ ou mais do capital ter acesso a informações que incluem a remuneração dos administradores, teria exaurido, com este mecanismo, a disciplina de divulgação da remuneração

\footnotetext{
${ }^{364}$ CAMPOS, Luiz Antonio de Sampaio. Deveres e Responsabilidades. In: LAMY FILHO, Alfredo; PEDREIRA, José Luiz Bulhões (coord.). Op. cit. p. 1.171.

${ }^{365}$ Id., ibid. p. 1.174-1.175.
} 
dos administradores. O item 13.11 do Anexo 24 da ICVM 480, ao criar obrigação relativa a esta matéria, estaria conflitando com a disciplina da LSA sobre o direito a informação do acionista em companhias abertas.

Com todo o acato e consideração pelos juristas que defendem esta tese, o Autor ousa discordar. Para expor seus motivos, fará várias considerações pontuais a respeito do art. $157, \S 1^{\circ}$, da LSA.

A primeira observação a se extrair do $\S 1^{\circ}$ do art. 157 é que ele somente se aplica a administradores de companhias abertas. Por óbvio, ficam desobrigados de cumprir com a obrigação dele constante os administradores de companhias fechadas, bem como os membros do conselho fiscal da qualquer companhia. Logo, de início já se pode perceber que a informação referida no item 13.11 do Anexo 24 da ICVM 480 referese a pessoas diferentes daquela referida no art. $157, \S 1^{\circ}$, da LSA.

Além disto, o próprio teor da informação é diferente. No Formulário de Referência (ICVM 480) exige-se a divulgação dos valores das remunerações máxima, mínima e média dentro da diretoria e dos conselhos de administração e fiscal. No art. $157, \S 1^{\circ}$, da LSA o acionista pode ter acesso a informações muito mais detalhadas sobre os incentivos e desincentivos econômico-financeiros dos administradores em relação à performance da companhia - basta notar a redação das alíneas $c$ e $d$.

Os destinatários da obrigação tampouco são os mesmos. Enquanto o art. $157, \S 1^{\circ}$, da LSA, obriga o administrador a revelar determinadas informações, a ICVM 480 obriga, antes, a própria companhia a fazê-lo. No primeiro caso, a responsabilidade por eventuais danos causados pelo administrador que, licitamente instado a fornecer informações, não as fornece, é do próprio administrador. No segundo caso, a ICVM 480 responsabiliza o diretor de relações com investidores, figura criada pelo art. 44 dessa mesma Instrução, sem prejuízo da responsabilidade dos 
administradores e controladores da companhia, dentro de suas atribuições legais e estatutárias (arts. 42, 43 e 46 da ICVM 480).

Também o regime de responsabilidade é distinto em cada caso. Em um trata-se de responsabilidade civil, circunscrita aos danos causados, por parte do administrador que nega pedido de fornecimento de informações formulado licitamente. No outro, trata-se de responsabilidade administrativa perante a CVM.

Por fim, são diferentes os titulares do direito. No caso do art. 157, $\S 1^{\circ}$, o direito de requisitar e ter acesso à informação é, muito claramente, do acionista detentor de $5 \%$ ou mais do capital social. Por outro lado, o titular do direito contido no item 13.11 do Anexo 24 da ICVM 480 é o próprio mercado.

Essas observações deixam claro que trata-se informações distintas, destinadas a atender a grupos de pessoas distintos, e, portanto, sujeitas a regimes distintos. Somente um acionista detentor de $5 \%$ ou mais do capital social pode tomar conhecimento de todas as vantagens e benefícios auferidos por um administrador, ou de seu contrato com a companhia. Contudo, caso queira conhecer as remunerações máxima e mínima dos membros do conselho de administração de uma companhia aberta, por exemplo, não precisa deter tal participação - na realidade, nem precisa ser acionista da companhia.

$\mathrm{O}$ art. $157, \S 1^{\circ}$, evidencia uma preocupação do legislador com o distanciamento entre o acionista e a companhia aberta e com a informação 
dos acionistas a respeito de remunerações, benefícios e vantagens percebidos pelos administradores e os executivos de alto nível. ${ }^{366}$

Por outro lado, a regulação exercida pela CVM sobre o mercado de capitais visa a fornecer aos investidores a informação de que ele precisa para tomar a melhor decisão de investimento. ${ }^{367}$

Trata-se, claramente, de situações distintas.

366 CAMPOS, Luiz Antonio de Sampaio. Deveres e Responsabilidades. In: LAMY FILHO, Alfredo; PEDREIRA, José Luiz Bulhões (coord.). Op. cit. pp. 1.174-1.175.

367 TRINDADE, Marcelo Fernandez. O Papel da CVM e o Mercado de Capitais no Brasil. In: SADDI, Jairo (org.) Fusões e Aquisições: aspectos jurídicos e econômicos. São Paulo: IOB, 2002. p. 309. 


\section{Conclusão global}

Ao longo deste trabalho se demonstrou que, sob uma ótica da Economia dos custos de transação, a remuneração dos administradores de companhias é vista como um mecanismo de incentivo e desincentivo de determinadas condutas. ${ }^{368}$ Também é vista, pelo menos nos EUA, como fruto de negociações empreendidas por um conselho de administração que pode estar sob a influência de um managerial power ou não. ${ }^{369}$

Também se demonstrou, que, por mais que possa ser desejável adotar, no Brasil, práticas salutares de transparência já adotadas nos EUA, a ótica norte americana de enxergar custos de agência oriundos da relação entre acionistas e administradores não se aplica inteiramente ao caso brasileiro.

Apesar de o Autor reconhecer que a informação é um bem precioso e que sua disseminação pelo mercado é benéfica ao investimento nacional, procurou deixar claro que a imposição de um modelo de disclosure, determinando a prestação exaustiva de informações, para todas as companhias abertas, provavelmente não é a solução mais eficiente do ponto de vista econômico. Embora a literatura sobre o tema seja reduzida, é possível associar a estas medidas um custo elevado de compliance, que o Autor suspeita não corresponder a um benefício proporcional para várias companhias.

Contudo, após empreender análise do poder normativo da CVM, o Autor entendeu que a legalidade dos recentes atos normativos da CVM que criaram o mandatory disclosure da remuneração de administradores de

\footnotetext{
${ }^{368}$ ELSON, Charles M. Op. cit.

369 BEBCHUK, Lucian; FRIED, Jesse. Pay without Performance: the unfulfilled promise of executive compensation.
} 
companhias abertas (Deliberação n. 560, ICVM 480 e ICVM 481) não está de forma alguma maculada.

Neste sentido, os argumentos do IBEF na ação judicial a que se referiu em outras ocasiões neste trabalho, pelo menos no que tocam à falta de poder normativo sobre a matéria, com todo o respeito a aqueles que os defendem, estão equivocados. Também estão equivocados os argumentos que dizem respeito à violação de dispositivos pontuais da LSA. O Autor espera ter demonstrado à satisfação que o item 13.11 do Anexo 24 da ICVM 480, em especial, é perfeitamente válido.

Como já dito, isto não significa que ele seja considerado bom ou ruim. O Autor prefere entender que o melhor disclosure é aquele acordado entre as partes - levado a cabo, por exemplo, por investidores institucionais, bolsas de valores e demais entes autorreguladores.

De todo modo, cabe o reconhecimento de que, como a própria ação IBEF v. CVM retrata, o tema da remuneração de administradores de companhias é, no Brasil, extremamente sensível. Sem razões institucionais - obrigatórias, diria-se - para fazer sua divulgação, é provável que os agentes privados jamais queiram fazê-lo. Outras soluções intermediárias, todavia, seriam possíveis. Por mais que esteja fora do escopo deste trabalho, seria interessante ver estudos sobre a proposta, pela CVM, de modelos de disclosure de adesão voluntária. Dando um passo atrás, a própria atuação institucional da CVM junto a órgãos autorreguladores é capaz de dar ensejo a soluções mais flexíveis e eficientes para o problema. 


\section{Bibliografia}

$5^{\text {a }}$ VARA DA SEÇÃO JUDICIÁRIA DA JUSTIÇA FEDERAL DO ESTADO DO RIO DE JANEIRO. Ação Ordinária. Processo n. 2010.51.01.002888-5.

ABREU, Jorge Manuel Coutinho de. Governação das Sociedades Comerciais, $2^{\mathrm{a}}$ ed. Coimbra: Almedina, 2010. 218 p.

ALCHIAN, Armen A.; DEMSETZ, Harold. Production, Information Costs, and Economic Organization. The American Economic Review, vol. 62. n. 5, 1972. pp. 777-795.

ARAGÃO, Alexandre Santos de. Agências Reguladoras e a Evolução do Direito Administrativo Econômico. Rio de Janeiro: Forense, 2009. 508 p.

BAINBRIDGE, Stephen M. The New Corporate Governance in Theory and Practice. Nova Iorque: Oxford University Press, 2008. 245 p. . Corporate Law, $2^{\mathrm{a}}$ ed. Foundation Press, 2009. $508 \mathrm{p}$.

Dodd-Frank: quack corporate governance round II. Minnesota Law Review, n. 95, 2010-2011. pp. 1.779-1.821.

Corporate Governance after the Financial Crisis. Nova Iorque: Oxford University Press, 2012. 283 p.

BAPTISTA NETO, José. O Projeto de Lei que Institui a Comissão de Valores Mobiliários (CVM). Revista de Direito Mercantil, Industrial, Econômico e Financeiro, ano XIV, n. 20, 1975. p. 111-114. 
BEBCHUK, Lucian; FRIED, Jesse; WALKER, David. Managerial Power and Rent Extraction in the Design of Executive Compensation. The University of Chicago Law Review, vol. 69, 2002. Disponível em <http://papers.ssrn.com/abstract_id=316590>. Acesso em 11 nov. 2013.

BEBCHUK, Lucian; FRIED, Jesse. Executive Compensation as an Agency Problem. The Journal of Economic Perspectives, vol. 17, n. 3, 2003. pp. 7192.

- Stealth Compensation via Retirement Benefits. Berkeley Business Law Journal, 2004. Disponível em <http://ssrn.com/abstract=583861>. Acesso em 11 nov. 2013.

. Pay without Performance: The unfulfilled promise of executive compensation. Harvard University Press, 2004. $278 \mathrm{p}$.

BEBCHUK, Lucian; COHEN, Alma; SPAMANN, Holger. The Wages of Failure: executive compensation at Bear Stearns and Lehman 2000-2008. ECGI Finance Working Paper n. 287/2010, jun. 2010. Disponível em <http://ssrn.com/abstract=1513522>. Acesso em 11 nov. 2013.

BERLE, Adolf A.; MEANS, Gardiner C. The Modern Corporation and Private Property. Transaction, 1991. 380 p.

BINENBOJM, Gustavo (coord.). Agências Reguladoras e Democracia. Rio de Janeiro: Lumen Juris, 2006. 251 p.

BINENBOJM, Gustavo. Uma Teoria do Direito Administrativo: Direitos fundamentais, democracia e constitucionalização. Rio de Janeiro: Renovar, 2008. $341 \mathrm{p}$. 
BLAIR, Margaret. Corporate Law and the Team Production Problem. Vanderbilt University Law School Public Law and Legal Theory Working Paper Number 12-14. Disponível em <http://ssrn.com/abstract_id=2037240>. Acesso em 25 out. 2013.

BM\&FBOVESPA. O que São Segmentos de Listagem. Disponível em <http://www.bmfbovespa.com.br/pt-br/servicos/solucoes-para-empresas/seg mentos-de-listagem/o-que-sao-segmentos-de-listagem.aspx ?idioma=pt-br> . Acesso em 11 nov. 2013.

BONNEAU, Thierry. Valeurs Mobilières et Titres Financiers en Droit Français. Revista de Direito Bancário e do Mercado de Capitais. n. 45, ano 12, jul. - set. 2009. pp. 197-206.

BUCHÈRE, Ambroise. Traité Théorique et Pratique des Valeurs Mobilières et Effets Publics, $2^{\mathrm{a}}$ ed. Paris: Marescq, 1881. 866 p.

CAMILO JUNIOR, Ruy Pereira. A Polêmica sobre a IN CVM 480/2009: comentários ao agravo regimental na suspensão de liminar e de sentença 1.210/RJ. Revista de Direito Bancário e do Mercado de Capitais. n. 51, ano 14, jan. - mar. 2011. pp. 261-281.

CARVALHOSA, Modesto. Comentários à Lei de Sociedades Anônimas, vol. 3. $5^{\mathrm{a}}$ ed. revista e atualizada. São Paulo: Saraiva, 2011. 981 p.

CHEFFINS, Brian R. The History of Corporate Governance. Working Paper n. 184/2012. ECGI Working Paper Series in Law, jan. 2012. Disponível em <http://ssrn.com/abstract=1975404>. Acesso em 17 out. 2013.

COASE, Ronald Harry. The Firm, the Market and the Law. The University of Chicago Press, 1988. 217 p. 
. The Nature of the Firm. Economica, New Series, vol. 4, n. 16, nov. 1937. pp. 386-405.

COMISSÃO NACIONAL DAS BOLSAS DE VALORES. Introdução ao Mercado de Ações. Rio de Janeiro: CNBV, 1984. 294 p.

COMMISSION OF THE EUROPEAN COMMUNITIES. COM (2003) 284. Company Law and Enhancing Corporate Governance in the European Union: a plan to move forward. Bruxelas, 21 mai. 2003.

COMPARATO, Fábio Konder. O Poder de Controle na Sociedade Anônima. São Paulo: Revista dos Tribunais, 1975. 426 p.

CORE, John E.;GUAY, Wayne R.; THOMAS, Randall S. Is U.S. CEO Compensation Inefficient Pay without Performance? Michigan Law Review, 103, 2004-2005. pp. 1.142-1.185.

CORKERY, Michael. Executive Pay and the Financial Crisis: a refresher course. The Wall Street Journal, 18 set. 2009. Disponível em <http://blogs.wsj.com/deals/2009/09/18/executive-pay-and-the-financialcrisis-a-refresher-course/>. Acesso em 11 nov. 2013.

DEMSETZ, Harold. The Cost of Transacting. The Quarterly Journal of Economics, vol. 82, n. 1, fev. 1968. pp. 33-53. . Toward a Theory of Property Rights. The American Economic Review, vol. 57, n. 2, Papers and Proceedings of the SeventyNinth Annual Meeting of the American Economic Association, 1967. pp. 347-359.

The Structure of Ownership and the Theory of the Firm. Journal of Law and Economics, n. 26, 1983. pp. 375-390 
DI PIETRO, Maria Sylvia Zanella. Discricionariedade Administrativa na Constituição de 1988, $2^{\mathrm{a}}$ ed. São Paulo: Atlas, 2001. 242 p.

DUBEUX, Julio Ramalho. A Comissão de Valores Mobiliários e os Principais Instrumentos Regulatórios do Mercado de Capitais. Porto Alegre: Sergio Antonio Fabris, 2006. 112 p.

EASTERBROOK, Frank H.; FISCHEL, Daniel R. The Economic Structure of Corporate Law. Harvard University Press, 1991. 370 p.

EISENBERG, Melvin A. The Conception that the Corporation is a Nexus of Contracts, and the Dual Nature of the Firm. Journal of Corporation Law, n. $24,1998-1999$. pp. 819-836.

EISENHARDT, Kathleen. Agency Theory: an assessment and review. The Academy of Management Review, vol. 14, n. 1, jan. 1989. pp. 57-74.

EIZIRIK, Nelson; GAAL, Ariádna B.; PARENTE, Flávia; HENRIQUES, Marcus de Freitas. Mercado de Capitais: Regime jurídico, $3^{\mathrm{a}}$ ed. revista e ampliada. Rio de Janeiro: Renovar, 2011. 660 p.

EIZIRIK, Nelson. Aspectos Modernos do Direito Societário. Rio de Janeiro: Renovar, 1992. 236 p.

O Mito do "Controle Gerencial": alguns dados empíricos. Revista de Direito Mercantil, Financeiro, Industrial e Econômico, ano XXVI, n. 66, abr. - jun. 1987. pp. 103-106.

Reforma das S.A. e do Mercado de Capitais. Rio de Janeiro: Renovar, 1997. 440 p. 
ELSON, Charles M. Director Compensation and the Management Captured-Board: the history of a symptom and a cure. SMU Law Review, vol. 50, 1996-1997. pp. 127-174.

FAGUNDES, Miguel Seabra. O Controle dos Atos Administrativos pelo Poder Judiciário. $8^{\mathrm{a}}$ ed. atualizada por Gustavo Binenbojm. Rio de Janeiro: Forense, 2010. 537 p.

FAMA, Eugene F. Agency Problems and the Theory of the Firm. Journal of Political Economy, vol. 88, n. 2, abr. 1980. pp. 288-307.

FIGUEIREDO, Lucia Valle. Curso de Direito Administrativo. $5^{\mathrm{a}}$ ed. revista, atualizada e ampliada. São Paulo: Malheiros, 2001. 633 p.

FORBES. Two Decades of CEO Pay. Disponível em $<$ http://www.forbes.com/lists/2012/12/ceo-compensation-12-historical-paychart.html>. Acesso em 11 nov. 2013.

FORGIONI, Paula A. Teoria Geral dos Contratos Empresariais, $2^{\mathrm{a}}$ ed. revista. Rio de Janeiro: Revista dos Tribunais, 2011. 271 p.

FRANÇA, Erasmo Valladão Azevedo e Novaes. Conflito de Interesses nas Assembléias de S.A. São Paulo: Malheiros, 1993. 109 p.

FURUBOTN, Eirik G.; PEJOVICH, Svetozar. Property Rights and Economic Theory: a survey of recent literature. Journal of Economic Literature, v. 10, n. 4, dez. 1972. pp. 1137-1162.

GORDON, Jeffrey N. "Say on Pay": cautionary notes on the U.K. experience and the case for shareholder opt-in. Harvard Journal on Legislation, n. 46, 2009. pp. 323-367. 
GORGA, Érica. Changing the Paradigm of Stock Ownership from Concentrated towards Dispersed Ownership? Evidence from Brazil and consequences for emerging markets. Disponível em <http://ssrn.com/abstract=1121037>. Acesso em 11 nov. 2013.

. Direito Societário Atual. Rio de Janeiro: Elsevier, 2013. $300 \mathrm{p}$.

GRAU, Eros Roberto. A Ordem Econômica na Constituição de 1988. 14 ${ }^{\mathrm{a}}$ ed. revista e atualizada. São Paulo: Malheiros, 2010. 391 p.

O Direito Posto e o Direito Pressuposto. $7^{\mathrm{a}}$ ed. revista e ampliada. São Paulo: Malheiros, 2008. 366 p.

HAURIOU, Maurice. Précis Élémentaire de Droit Constitutionnel. $2^{\mathrm{a}}$ ed. Paris: Sirey, 1930. 332 p.

HEALY, Paul. The Effect of Bonus Schemes on Accounting Decisions. Journal of Accounting and Economics, n. 7, 1985. p. 85-107.

HOUSE OF REPRESENTATIVES OF THE UNITED STATES OF AMERICA. Report 110-88. 22 p.

Sixty-Third Congress. Committee on Interstate and Foreign Commerce. Regulation of the Issuance of Stocks and Bonds by Common Carriers. Hearings before the Committee on Interstate and Foreign Commerce. Washington: Government Printing Office, 1914. 250 p.

JENSEN, Michael C. Foundations of Organizational Strategy. Nova Iorque: Harvard University Press, 1998. 414 p. 
. A Theory of the Firm: governance, residual claims, and organizational forms. $2^{\mathrm{a}}$ tiragem. Nova Iorque: Harvard University Press, 2000. 311 p.

JENSEN, Michael C.; MECKLING, William H. Theory of the Firm: managerial behavior, agency costs and ownership structure. Journal of Financial Economics, vol. 3, n. 4, 1976. Disponível em <http://papers.ssrn.com/abstract=94043> Acesso em 08 out. 2013.

KANSAS OFFICE OF THE SECURITIES COMMISSIONER. History. Disponível em < http://www.ksc.ks.gov/index.aspx?nid=154>. Acesso em 11 nov. 2013.

KELLER, Christopher; STOCKER, Michael. Executive Compensation's Role in the Financial Crisis. The National Law Journal, 18 nov. 2008. Disponível em <http://www.law.com/corporatecounsel/PubArticleCC.jsp?id=1202426091 714\&slreturn=20131010210943> Acesso em 11. nov. 2013.

LAMY FILHO, Alfredo; PEDREIRA, José Luiz Bulhões (coord.). Direito das Companhias, 2 vols. Rio de Janeiro: Forense, 2009. 2.230 p.

LEÃES, Luís Gastão Paes de Barros. Mercado de Capitais e "Insider Trading”. São Paulo: Revista dos Tribunais, 1982. 198 p.

LEAL, Victor Nunes. Problemas de Direito Público e Outros Problemas. vol. 1. Brasília: Imprensa Nacional, 1999. 482 p.

LOBO, Carlos Augusto da Silveira. Advocacia de Empresas. Rio de Janeiro: Renovar, 2012. 490 p. 
LOBO, Jorge (coord.) Reforma da Lei das Sociedades Anônimas: inovações e questões controvertidas da Lei ${ }^{\circ} 10.303$, de 31.10.2001. Rio de Janeiro: Forense, 2002. 584 p.

LUCENA, José Waldecy. Das Sociedades Anônimas: Comentários à Lei, v. 1. Rio de Janeiro: Renovar, 2009. 1.232 p.

MALLIN, Christine A. Corporate Governance. $4^{\mathrm{a}}$ ed. Nova Iorque: Oxford University Press, 2013. 384 p.

MARTIN, Susan Lorde. The Executive Compensation Problem. Dickinson Law Review, n. 98, 1993-1994. pp. 237-257.

MATTOS FILHO, Ary Oswaldo. O Conceito de Valor Mobiliário. Revista de Direito Mercantil, Industrial, Econômico e Financeiro, ano XXIV, n. 59,1985 . p. $30-55$.

MCGUINESS, John F. Impact of Sarbanes-Oxley Act on Benefits and Executive Compensation. Journal of Deferred Compensation, n. 8, vol. 2. pp. 55-68.

MEIRELLES, Hely Lopes. Direito Administrativo Brasileiro. $25^{\mathrm{a}}$ ed. atualizada por Eurico de Andrade Azevedo, Délcio Balestero Aleixo e José Emmanuel Burle Filho. São Paulo: Malheiros, 2000. 765 p.

MELLO, Celso Antônio Bandeira de. Curso de Direito Administrativo. $28^{\mathrm{a}}$ ed. revista e atualizada. São Paulo: Malheiros, 2011. 1.127 p.

MOREIRA NETO, Diogo de Figueiredo. Mutações do Direito Público. Rio de Janeiro: Renovar, 2006. 442 p. 
NEGREIROS, Teresa. Remuneração e Risco no Setor Financeiro: novidades e tendências na Europa. Revista de Direito Bancário e do Mercado de Capitais, ano 14, n. 52, jan. - mar. 2011. pp. 197-212.

OCASIO, William; JOSEPH, John. Cultural Adaptation and Institutional Change: the evolution of vocabularies of corporate governance, 1972-2003. Poetics, n. 33, 2005. pp. 163-178.

ORGANIZATION FOR ECONOMIC CO-OPERATION AND DEVELOPMENT. OECD Principles of Corporate Governance. Disponível em <http://www.oecd.org/daf/ca/oecdprinciplesofcorporategovernance. htm>. Acesso em 10 nov. 2013.

PAK, Charles C. Toward Reasonable Executive Compensation: outcry for reform and regulatory response. 1994 Annual Survey of American Law, 1994. pp. 633-667.

PARDESSUS, Jean-Marie. Cours de Droit Commercial, t. 3. Paris: Garnery, 1815. 486 p.

PEREIRA, Caio Mário da Silva. Instituições de Direito Civil, vol. 1, 23ª ed. revista e atualizada por Maria Celina Bodin de Moraes. Rio de Janeiro: Forense, 2009. 608 p.

PIETRO, Maria Sylvia Zanella di. Discricionariedade Técnica e Discricionariedade Administrativa. Revista Eletrônica de Direito Administrativo Econômico, n. 9, fev. - abr. 2007. Instituto Brasileiro de Direito Público. $\quad$ Disponível em <http://www.direitodoestado.com/revista/REDAE-9-FEVEREIRO-2007MARIA\%20SYLVIA.pdf >. Acesso em 11 nov. 2013. 
PINHEIRO, Armando Castelar; SADDI, Jairo. Direito, Economia $e$ Mercados. $2^{\mathrm{a}}$ reimpressão. São Paulo: Elsevier, 2005. 553 p.

REQUIÃO, Rubens. A Sociedade Anônima como "Intituição". Revista de Direito Mercantil, Industrial, Econômico e Financeiro, ano XIV, n. 18, 1975. pp. 25-38.

- Considerações sobre o Projeto de Criação da Comissão de Valores Mobiliários (CVM). Revista de Direito Mercantil, Industrial, Econômico e Financeiro, ano XIV, n. 20, 1975. pp. 101-109.

REVELL, Janice. Mo' Money, Fewer Problems: is it a good idea to get rid of the $\$ 1$ million CEO pay ceiling? Fortune, 31 mar. 2003. Disponível em $<$ http://money.cnn.com/magazines/fortune/fortune_archive/2003/03/31/340 098/index.htm>. Acesso em 09 nov. 2013.

RIPERT, Georges. Traité Élémentaire de Droit Commercial. Paris: LGDJ, 1948. $1.105 \mathrm{p}$.

Aspectos Jurídicos do Capitalismo Moderno, trad. por Gilda G. de Azevedo. Rio de Janeiro: Freitas Bastos, 1951. 366 p.

ROCHA, Bolívar B. M. O Poder Normativo de Órgãos da Administração: o caso da Comissão de Valores Mobiliários. Revista de Direito Mercantil, Industrial, Econômico e Financeiro, ano XXV, n. 64, out. - dez. 1986. pp. 47-69.

ROMANO, Roberta. The Sarbanes-Oxley Act and the Making of Quack Corporate Governance. Yale Law Journal, n. 114, 2004-2005. pp. 1.5211.611 .

. Does the Sarbanes-Oxley Act Have a Future? Yale Journal on Regulation, n. 26, 2009. pp. 229-341. 
ROSS, Stephen A. The Economic Theory of Agency: the principal's problem. The American Economic Review, vol. 63, n. 2, Papers and Proceedings of the Eighty-fifth Annual Meeting of the American Economic Association, mai. 1973. pp. 134-139.

SELIGMAN, Joel. The Transformation of Wall Street, $3^{\mathrm{a}}$ ed. Wolters Kluwer, 2003. 934 p.

SMITH, Adam. The Wealth of Nations, editado por Edwin Cannan, vol. 1. Londres: Methuen, 1904. 497 p.

STIGLER, George J. The Organization of Industry. The University of Chicago Press, 1983. 328 p.

STOUT, Lynn. The Shareholder Value Myth: how putting shareholders first harms investors, corporations, and the public. São Francisco: BerrettKoehler, 2012. 134 p.

SUPREME COURT OF THE UNITED STATES OF AMERICA. Securities Exchange Commission v. C. M. Joiner Leasing Corporation Co. et al. U.S. Report, vol. 320. pp. 344-355.

Securities Exchange Commission v. W. J. Howey Co. et al. U.S. Report, vol. 328. pp. 293-302.

SZTAJN, Rachel. Direito e Economia. Revista de Direito Mercantil, Industrial, Econômico e Financeiro, vol. 144, out. - dez. 2006. pp. 221235.

TÁCITO, Caio. Agências Reguladoras da Administração. Revista de Direito Administrativo, vol. 221, jul. - set. 2000. pp. 1-5. 
THALLER, E. Traité Élémentaire de Droit Commercial. Paris: Rousseau, 1898. 1.080 p.

THE COMMITTEE ON THE FINANCIAL ASPECTS OF CORPORATE

GOVERNANCE. Report of the Committe on the Financial Aspects of Corporate Governance, 01 dez. 1992.

UNITED STATES SECURITIES AND EXCHANGE COMMISSION. Release No. 34-68640. 11 jan. 2013.

Releases Nos. 33-9452; 34-70443. 18 set. 2013.

UNITED STATES. Federal Register, vol. 57, n. 204, 21 out. 1992.

VALADARES, Sílvia Mourthé; LEAL, Ricardo Pereira Câmara. Ownership and Control Structure of Brazilian Companies. Disponível em <http://ssrn.com/abstract=213409>. Acesso em 11 nov. 2013.

WEIL, GOTSHALL \& MANGES. Comparative Study of Corporate Governance Codes Relevant to the European Union and its Member States, Final Report \& Annexes I-III. 107 p.

WELLS, Harwell. "No Man Can Be Worth \$1,000,000 a Year": the fight over executive compensation in 1930s America. University of Richmond Law Review, n. 44, 2009-2010. pp. 689-769.

WILLIAMSON, Oliver E. Managerial Discretion and Business Behavior. The American Economic Review, vol. 53, n. 5, dez. 1963. pp. 1.032-57.

. The Theory of the Firm as Governance Structure: from choice to contract. The Journal of Economic Perspectives, vol. 16, n. 3, 2002. pp. 171-195. 
. The Economics of Governance. The American

Economic Review, vol. 95, n. 2, Papers and Proceedings of the One Hundred Seventeenth Annual Meeting of the American Economic Association, mai. 2005. pp. 1-18.

- Transaction Cost Economics: the natural progression. The American Economic Review, vol. 100, n. 3, jun. 2010. pp. 673-690.

WILLIAMSON, Oliver E.; WINTER, Sidney G. (eds.). The Nature of the Firm: origins, evolution, and development. Oxford University Press, 1993. 244 p.

WILSON, Robert. The Theory of Syndicates. Econometrica, vol. 36, n. 1, jan. 1968. pp. 119-132.

YAZBEK, Otavio. Regulação do Mercado Financeiro e de Capitais. $2^{\mathrm{a}}$ ed. ampliada. Rio de Janeiro: Elsevier, 2009. 322 p. 